
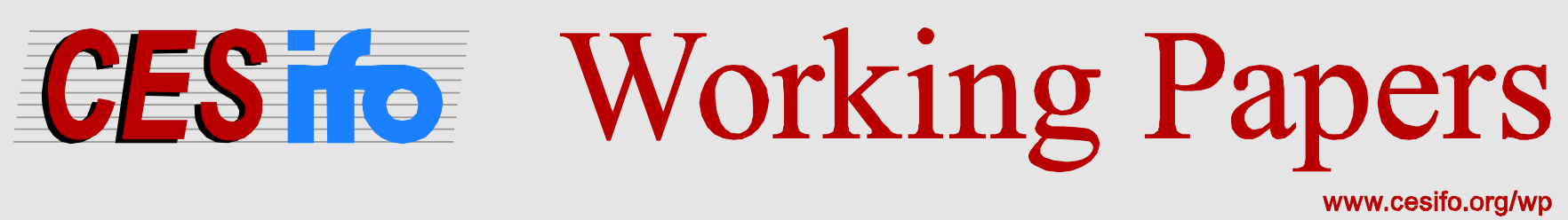

\title{
Lost in America: Evidence on Local Sales Taxes from National Panel Data
}

\author{
David R. Agrawal
}

CESIFO WORKING PAPER NO. 4943

CATEgory 1: Public FinANCE

August 2014

An electronic version of the paper may be downloaded

- from the SSRN website:

- from the RePEc website:

- from the CESifo website:

WwW.SSRN.com

www.RePEc.org

www.CESifo-group.org/wp 


\title{
Lost in America: Evidence on Local Sales Taxes from National Panel Data
}

\begin{abstract}
This paper studies comprehensive national panel data of local option sales taxes at the monthly frequency. I calculate state-by-month population weighted averages of local sales tax rates. I document ten stylized facts concerning the time series patterns and spatial dynamics of local sales taxes. The paper then considers a "tax system" approach to tax competition where states compete on a variety of margins that are often ignored by the standard focus on tax rates. Using the state-by-month averages, I find a significant association between one state's tax system and its neighboring states' tax systems.
\end{abstract}

JEL-Code: H200, H710, H770, K340, L810, R100, R500.

Keywords: commodity taxation, local public finance, fiscal federalism, spatial tax competition, tax systems, municipal autonomy.

\author{
David R. Agrawal \\ University of Georgia \\ Department of Economics \\ 527 Brooks Hall \\ USA - Athens, GA 30602 \\ dagrawal@uga.edu
}

This Version: June 2014

Sanjukta Das, Nabaneeta Biswas, and John Kim provided excellent research assistance. Thank you to Adam Cole, Michael Eriksen, Andrew Hayashi, William Lastrapes, Olga Malkova, David Mustard, Edgar Olsen, John Turner, Gary Wagner and David Wildasin for many discussions on the topic. Conference participants at the National Tax Association Meetings and the Southern Economic Association Meetings helped to improve the paper. Thanks to Pro Sales Tax for providing me access to the sales tax data. Any remaining errors are my own. 


\section{Introduction}

This paper documents both the time and spatial dynamics of location option sales taxes (LOST) using high frequency national panel data. Local option sales taxes are the second largest own-source of revenue for local governments other than the property tax. On average, LOST raise $12 \%$ of municipal revenue, with this number being as high as $43 \%$ in the state of Louisiana (Sjoquist and Stoycheva 2012; Mikesell 2010). Many researchers have documented changes in local sales tax revenue over recent decades. However, little is know about the pattern of tax rates from a national perspective. Although tax revenue patterns help understand the volatility of LOST, information on tax rates is also essential to determining how municipalities and counties compete with each other. In addition, the researcher would need access to tax rates to estimate the tax incidence of commodity taxes or the behavioral response to sales taxes. Because of the difficulty of assembling a national panel data set of municipalities, many tax incidence and cross-border shopping studies focus on a sub-set of metropolitan areas or a single state border. If the researcher only observes state tax rates, the researcher will incorrectly measure tax differentials across time and space.

This paper represents the first attempt to assemble national panel data on LOST for state, county, town and special districts. I have constructed a database of every district, municipal, county, and state sales tax rate in the United States between 2003 and 2012. The data are high-frequency; I observe the tax rates at the monthly frequency. Armed with this data in hand, I am able to document important yet previously unknown facts concerning the time and spatial dynamics of these important tax rates.

The goal of this paper is four-fold. First, I will describe the institutional features of LOST on a state-by-state basis. When working with national data it is important to understand the institutional limitations. In some circumstances, comparisons across states are not valid. As such, I have carefully analyzed state statutes governing LOST and I outline noteworthy institutional structures governing these taxes that vary across states. Second, I develop state-by-month local sales tax rate indexes. These indexes are designed to allow researchers who have state level data to include a measure of the population weighted local sales tax rate on top of the statutory state tax rate observed. Third, I use the indexes to document ten stylized facts regarding LOST. How have LOST changed over time? What type of jurisdictions change tax rates? How does the variation of taxes change within states? Has the Great Recession changed tax setting behavior? What are the dynamics of tax rate changes? Despite the simplicity of these questions, we know very little of their answers at the national level beyond what we have learned by studying particular states and we certainly have not been able to study tax changes using such high frequency data. The 
answers to these questions suggest fruitful future research topics concerning LOST - that may be answered using using the constructed local tax data made available in this paper or a single state case study.

Finally, the paper then turns from time series patterns of LOST to spatial correlations of these changes over time. I show that the tax rate series that I construct can be applied to empirically study outcomes across states. The application I study is fiscal competition across states. Not accounting for local tax data when studying state sales tax competition will inaccurately measure the intensity of spatial relationships across jurisdictions. I also provide evidence that states compete for mobile shoppers by selecting a tax system as a whole (inclusive of the local tax rates) rather than a single state tax rate. Although municipalities have freedom to choose their tax rates, they do so in an environment that is dictated by the state government (Dillon's Rule). ${ }^{1}$ Through these legal constraints, states can dictate whether or not the average municipal tax rate in a state will be high or low - or in states that prohibit LOST, that it will be zero. The spatial pattern in the total local tax rate across states is especially strong. This suggests that a tax system approach (Slemrod and Gillitzer 2013 and Slemrod and Gillitzer 2014) is important. In applying this data to the tax competition setting, I focus on identifying spatial patterns in the data that are suggestive of tax competition. These spatial statistics complement the stylized facts documented using time series data.

Single state studies of LOST are extremely useful because they are able to isolate particular institutional features of state tax law. However, single state studies of local taxes are limited in other respects including how generalizable the results are to states with different legal and governing institutions. Further, without national data, (1) the researcher cannot accurately measure tax discontinuities that vary at borders, (2) cross-state comparisons cannot be made concerning factors influencing the variance of LOST within states and (3) comparisons exploiting exogenous vertical relationships between state institutions and municipal tax rates are much more difficult. The national panel data constructed and released in this paper allows the researcher to more accurately exploit variations in state level policies affecting LOST and spatial discontinuities at borders. Correcting for local tax rates in cross-state studies is especially important given that it is the state government that decides how much authority to grant to municipal governments. Although it is the locality that chooses the tax rate for its jurisdictions, it selects this rate in the context of state regulations that may cap the maximum tax rate, may dictate the rates that can be chosen, and may determine the levels of government that have taxing authority. As such, state based policies

\footnotetext{
${ }^{1}$ For legal discussion of Dillon's Rule and the authority of local governments more generally, please see Cohn (1957), Schragger (2001), and Schragger (2006).
} 
are important to influencing the magnitude of local taxes; in the extreme case, the state can dictate these taxes are zero by not allowing for LOST authority. These legal regulations that the state adopts work to constrain localities and influence how high local tax rates will be, which then influences behavioral responses. As such, how flexible the LOST system is (in addition to the state statutory tax rate) influences the extent of cross-border shopping, firm location decisions, employment, tax incidence and other behaviors sensitive to tax policies.

Despite the dramatic variation across jurisdictions and across time in local sales tax rates for the United States, few empirical studies exploit this variation to estimate behavioral responses to local tax rates. The main reason for excluding local tax variation is not a result of their lack of importance, but rather because of an absence of comprehensive national panel data on local sales tax rates across the country. The absence of such a panel inhibits us from studying central problems in regional economics and in local public finance. In such a context, the results in this paper are useful for correcting for the dramatic differences in the average level of local sales tax rate across states.

In addition to improving the measurement of tax differentials across states and average rates within states, the data will also be useful to incorporate sales tax components into price indexes essential to measuring quality of life across cities. The Council for Community and Economic research and its predecessor, the ACCRA, publish consumer price indexes for various urban areas across the United States. However, it is often ignored that these price indexes represent the net price to sellers and not the net price to buyers. In their description of the the price indexes, the Council for Community and Economic Research notes that it attempts to "produce an index which adequately measures differences in goods and services costs, rather than to produce an inaccurate measure which attempts to incorporate taxes." Given that state sales tax rates are around 5\% and that local taxes vary substantially across states, not correcting for state and local sales taxes could result in substantial measurement error in these price indexes. While correcting for state sales tax rates may be possible, the data to correct for local sales tax rates is not readily available. For example, if a researcher were correcting the price index for New York based solely on the state tax rate (4\%), the researcher would ignore that local tax rates (average: 4.5\%) in New York are on average higher than the state tax rate. Carrillo, Early and Olsen (2012) is an example of a study that produces the best price measures to date, but would benefit from having access to panel data on local sales tax rates at the state level. ${ }^{2}$ The results in this paper will be of use to urban and regional economists seeking to correct price indexes and to public finance

\footnotetext{
${ }^{2}$ Other studies using the ACCRA include Baum-Snow and Pavan (2012), Dumond, Hirsch and Macpherson (1999), and Winters (2009). Albouy (2012) adjusts the cost of living for state sales tax differences but not for local tax differences.
} 
economists seeking to more accurately measure behaviors and this paper aims to be the reference piece on LOST.

Up until recently, comprehensive studies across municipalities were limited by data availability. The increased access to "big data" at the state and local level allows the researcher to conduct cross-municipal and cross-county studies that exploit a great deal of variation in an open economy setting. I view the study of municipal tax setting behavior as an unique way to answer open economy questions that cannot be studies at the national level.

\section{Studies of LOST and State Sales Tax Rates}

In this section I review studies of local option sales taxes with an emphasis on papers that look at tax rates rather than the revenue implications of LOST. For survey pieces describing sales taxation at the state and local level - along with revenue trends over time - please see Fox (2012) and Sjoquist and Stoycheva (2012).

Following theoretical work on commodity tax competition (Mintz and Tulkens 1986; Kanbur and Keen 1993; Trandel 1994; Haufler 1996 Nielsen 2001) ${ }^{3}$ several studies analyze tax competition in the presence of local option sales taxes. Most of these studies focus on one particular state because they require data on sales tax rates to identify fiscal competition. ${ }^{4}$ Some examples include Zhoa (2005) and Sjoquist et al. (2007) who study tax competition in the state of Georgia. Luna (2003) and Luna, Bruce and Hawkins (2007) study the rate setting behavior, including the phenomenon of "maxing out," in the state of Tennessee. Rogers (2004), Burge and Rogers (2011), and Burge and Piper (2012) study fiscal interdependence and local adoption of sales taxes in the state of Oklahoma. Several recent studies exploit national cross-section data on LOST. Agrawal (2011)/Agrawal (forthcoming), Agrawal (2013a), and Agrawal (2013b) use a single national cross-section of LOST rates to estimate fiscal reaction functions for both horizontal, diagonal, vertical strategic interactions and interactions with e-commerce. These represent the first three papers to use a national cross-section of all municipal and county sales tax rates in the country.

A much broader literature on tax evasion, tax incidence, firm location decisions, and consumer behavioral responses to commodity taxation has exploited variation at the state or metropolitan level. Some of these studies do not have data on local sales tax rates. Others have used selected samples of MSAs or particular border-pairs. For example, Poterba

\footnotetext{
${ }^{3}$ Other studies such as Hoyt (2001) consider the optimal tax considerations of sales taxation in a federation.

${ }^{4}$ Other studies such as Benjamin and Dougan (1997), Devereux, Lockwood and Redoano (2007) and Jacobs, Ligthart and Vrijburg (2010) have analyzed commodity tax competition at the state level - although many of these studies focus on excise taxes. Knight and Schiff (2012) focus on cross-border shopping for state lotteries.
} 
(1996) studies and sample of fourteen cities and Besley and Rosen (1999) use a sample of approximately 150 cities in the United States; both studies find that the after-tax price increases by exactly the amount of the tax. Studies exploiting tax differentials at state borders to identify employment effects resulting from sales tax differentials have emphasized state tax rates (Thompson and Rohlin (2012); Rohlin, Rosenthal and Ross (2012)). Studies estimating the behavioral response (cross-border shopping) to sales taxes include Mikesell (1970), Fox (1986), Walsh and Jones (1988), and Tosun and Skidmore (2007). These studies traditionally use a single state or border-pair combination to identify fundamental elasticities. Tax evasion has also been studied in the context of the Internet in Goolsbee (2000), Ballard and Lee (2007), and Einav et al. (2013); all of these studies observe some data on either city or county sales tax rates. Cole (2009) uses state tax rates to study the impact of sales tax holidays on both prices and quantities; states may differ in how sales tax holidays are treated by municipalities and the author has used some of the data in this paper to account for LOST. The volatility of the sales tax has also been studied in the context of a single state by Hou and Seligman (2008) and in the national context with only state tax rate changes (Seegert 2012). Many of the previous studies have transformed the public finance literature concerning the effects of sales taxation. Having access to panel data provides researchers the ability to broaden their samples beyond one particular border and has the potential to allow the researcher to estimate more precise estimates than they would in a world where only the state tax rate is observed. Even if the researcher does not observe all local tax rates in the country, aggregated measures of local tax rates could effectively modify these studies by allowing for a more accurate measure of the average differentials and incentives.

\section{$3 \quad$ State Institutional Details}

The purpose of this paper is not to highlight the exact technicalities of how LOST are implemented in different states. Sjoquist and Stoycheva (2012) and Mikesell (2010) are excellent reviews in that respect. I do wish to point out several important institutional features of LOST that are especially important yet often not discussed; they help guide the researcher on when across state comparisons are valid. The implementation of LOST varies extensively across states. One possible explanation as to why LOST may vary across states is that states are implementing a "tax system" as a whole rather than a statutory tax rate. As noted in Slemrod and Gillitzer (2013), states design tax systems, not just tax rates. As such, states have a variety of policies that they may implement concerning LOST. States may select their statutory tax rate jointly with how LOST is established in the state. Both of these factors matter to cross-border shoppers - not just the state tax rate. In so much as 
localities are constrained as "creatures of the state," the resulting local policies may actually be a choice made by the state. Several differences across states exist with respect to their sales tax system - including, but not limited to:

- Statutory state tax rates vary across states.

- What is included in the taxable base varies - especially with respect to the treatment of food purchases.

- Some states do not allow local sales tax rates.

- The LOST tax base may or may not be the same as the state tax base. In states such as Louisiana, parishes have a say over what is subject to LOST; this adds substantial complexity into the tax system.

- The levels of government that are designated taxing authority by the state may include town, county, and district governments. States may allow some or all of these layers to levy taxes. In the tables to follow, the reader can observe what levels of government are authorized to set tax rates in each state.

- The procedures concerning how local jurisdiction may pass tax rates (voter referendum or by council approval) differ; these differences may make it harder for localities to adopt LOST in some states.

- The treatment of food varies in states allowing LOST. In some states, food purchases are exempt from the state tax rate but not the local rate; in other states, the reverse is true. In some states, local tax rates on food are assessed at a preferential tax rate.

- Some states cap localities by dictating a maximum LOST rate. When the maximum rate is low, many jurisdictions may max out.

- In other states, localities who want to adopt a LOST must pass a minimum tax rate. Related to this point, some states require all counties to adopt a uniform local option tax rate imposed by the state, but for which the revenue is distributed locally.

- In some states, localities have the authority to set any rate they want while in others, they must pass tax rates in certain increments, such as $1 / 4$ percentage point changes.

- In at least one state, the LOST rates sunset and automatically go back to zero after a certain number of years. 
- The county tax rates need not be uniform within a county in some states. Whether county tax rates apply in incorporated places, unincorporated places, or both and how tax revenues are distributed accordingly depends on state legislation.

- The size of special taxing districts vary. In some states special districts are submunicipal, but they may also be super municipal - perhaps even corresponding to the county borders. Special districts include ambulance or fire districts or transit districts that have special taxing authority. Districts does not mean school districts.

- Who is in charge of collecting and administering local rates may be either the state or local governments.

- Rules governing use taxes - the tax dues when the resident of the assessing state purchases an item that is not subject to his home state's sales tax - also vary. Whether localities are allowed to assess use taxes and how use taxes are enforced varies greatly. ${ }^{5}$

- Given recent efforts by states to broaden the definition of nexus, the rules of nexus also vary across states. A firm has nexus (generally) if it has a physical presence in the state from which in profits. In states with click-through nexus laws, firms such as Amazon may be required to collect state and local taxes despite not having a conventional physical presence in the state.

- Some states have entered into the Streamlined Sales and Use Tax Agreement. This agreement mainly influences tax administration and tax bases, but in its current form does not require states to give up local sales tax rates.

Given all of these complexities, one may wonder whether national data is useful to the researcher. Although the econometrician cannot account for all of these varying policies, the researcher can benefit from within state local variation, from more precise measurement of tax differentials at state borders, and across-state aggregate variation in the statutory local tax rates. For researchers with access to national LOST data and who seek to study issues relating to municipal public finance, the researcher must (in most circumstances) be sure to include state fixed effects such that all identifying variation come from within a state. For researchers seeking to study across state issues, the researcher cannot observe enforcement variations or nuanced definitions of the tax base across states. However, controlling for local tax rates will likely result in a first order improvement to the effective tax rates within a states. In the tax competition application in this paper, I will not be able to view the tax

\footnotetext{
${ }^{5}$ For a discussion of how use tax enforcement varies by state, see Agrawal (2013c).
} 
system as a whole across time and across states, but I will at least be able to study tax competition accounting for all levels of government.

\section{Data}

The data on sales tax rates at all levels of government comes from ProSales Tax's national database for months in years 2003 to $2011 .^{6}$ The high-frequency nature of the data will be valuable to analyzing both short- and long-term strategic interactions. Although the tax data tells me information about sales tax rates, I do not observe differences in the sales tax base. In most states, the sales tax base is common within a state. I do not observe property tax rates or other tax rates.

The data contain the sales and use tax rates on retail sales, but do not include special tax rates on items such as food. ${ }^{7}$

\section{Constructing State Based Statistics}

Data on state sales tax rates are readily available and are often used in studies that exploit panel variation and in studies that use state borders as a means of identification. Agrawal (2011) shows a dramatic "level-effect" of state tax rates on local tax rates: on average local sales taxes are 1.20 percentage points higher on the high-tax side of state borders. Although local sales taxes exhibit spatial gradients away from state borders, the overall level effect persists in state based averages. This suggests that a researcher without local data on sales taxes (or a researcher who has local tax data, but for which outcome variables may only be available at the aggregated state level), the researcher would want to observe a statelevel aggregated total effective tax rate (state plus county plus town plus district taxes). In this section, I propose a metric to create a weighted average of local sales tax rates under particular assumptions and I construct a panel of state level tax aggregates at the monthly

\footnotetext{
${ }^{6}$ ProSales Tax is a proprietary company that collects local sales tax data and then sells the data to firms with nexus in many different states. For information on the national database, please see http://www.prosalestax.com/. Although the data were provided to me by this firm, substantial cleaning needed to be conducted in order to make the data consistent over time due to border changes, etc. The appendix describes all of the cleaning done to the data.

${ }^{7}$ In the United States, commodity taxation falls under the jurisdiction of both sales and use tax rates. When a consumer purchases a good from a firm with a physical presence in a state, the consumer pays the sales tax rate at the point of transaction. The use tax rate is the rate that a consumer should remit to the government if they purchase an item from a firm outside of the jurisdiction that they reside; most states allow consumers to declare a credit against any sales taxes already paid in another state. In the United States, the use tax is notoriously under-enforced, and as a result, taxation is effectively levied on the basis of the origin of the sale.
} 
frequency. To construct a state level aggregate of local sales taxes, I merge (following the procedure in the appendix) data on local sales tax rates from my database with population data from the American Community Survey and the United States Census.

The ideal measure of the effective tax rate for the average resident of a particular state would account for tax evasion opportunities - whether they be on the Internet or in neighboring jurisdictions. However, cross-border flows across all 25,000 localities in the United States are not observable to the researcher. This leads to a necessary assumption to create a state level aggregate of local sales taxes: that shopping occurs and is taxed in the place of residence. This assumption is similarly equivalent to assuming that the use tax is effectively enforced. As such, the tax rates in the table to follow should not be interpreted as the population weighted effective tax rate in the state; rather, they should be interpreted as the population weighted statutory tax rate under the destination principle. ${ }^{8}$ The destination principle, although not actively enforced, is the legal statutory requirement to pay taxes on commodities.

Two points of discussion are in order. First, the direction of the bias from defining the weighted averages based on the of the town of residence is unclear. For states where residents engage in cross-border shopping in order to avoid state and local taxes, the metrics I construct will overestimate the average effective tax rates. However, because $30 \%$ of the U.S. population does not live in an incorporated area and the majority of incorporated areas are small, for these individuals, their home towns are small and likely do not have retail stores within their home town. As a result, these individuals will shop in nearby larger jurisdictions where the tax rate is likely higher than in their home town. ${ }^{9}$ Intuitively, because these two effects are offsetting, they are likely to only have a small bias on the aggregated metrics I construct.

Second, the choice of population weights merits some discussion. One might argue that the amount of retail sales may be a better choice of weights compared to population. Retail sales at the local level are difficult to obtain for all states in the United States. Only some states publish taxable sales data and even if states did publish the data, weighting by a variable that is endogenous to the tax rates would not be desirable. Although migration may respond to tax differentials, it is not likely that the population distribution within a state will be sensitive to sales tax differentials because differentials within a state are relatively small and because the sales tax can be easily evaded.

Letting $i$ index the municipal level of government, $k$ index states and $t$ index the month,

\footnotetext{
${ }^{8}$ Studies using the statutory state tax rate suffer from the same problems; the statutory state tax rate is not the effective tax rate across jurisdictions. Tax incidence (Harding, Leibtag and Lovenheim (2012)) and prices may also vary within a state, which may influence the true effective tax rate.

${ }^{9}$ Standard models of tax competition such as show that larger jurisdictions set higher tax rates.
} 
aggregated measures of the sales tax rates can be constructed in the following manner. I estimate $E\left(\tau_{i, k, t}\right)$ as the population weighted average given by:

$$
\tau_{k, t}^{-}=\frac{\sum_{i \in \Theta_{k}} \tau_{i, k, t} p_{i}}{\sum_{i \in \Theta_{k}} p_{i}}
$$

where $\tau$ denotes the municipal tax rate, $p$ is the population of a town or unincorporated place $i$ within a particular county, ${ }^{10}$ and $\bar{\tau}_{s}$ is the weighted tax rate for state $s . \Theta_{k}$ is the set of towns in state $k$; it contains one element for each town $i$. Notice that I construct the weighted averages holding population fixed; I can use either 2000 Census populations or 2010 ACS population numbers; the results from both exercises are similar. ${ }^{11}$ The population weighted district tax rate is also defined by the form of equation 1 . Denote the district tax in town $i$ as $\delta_{i, k, t}$ and the population weighted average of the district tax rates as $\delta_{k, t}^{-}$. For details on the assignment of districts to towns, please see the appendix.

Because taxation occurs at multiple levels of government, I also define population weighted average county tax rates. Defining $T$ as the county tax rate, then the state weighted average can be constructed as

$$
\overline{T_{k, t}}=\frac{\sum_{i \in \Theta_{k}} T_{i, k, t} p_{i}}{\sum_{i \in \Theta_{k}} p_{i}}
$$

Notice the weighting occurs at the town level rater than the county level; this is because in some states, county tax rates have different rates depending on whether areas are home rule or not. In most states, where county tax rates are common within a county, weighting at a more disaggregated level will yield the same weighted average as using the county populations weights. Let $\zeta_{k, t}$ denote the state sales tax rate. Then, the population weighted average of

\footnotetext{
${ }^{10}$ Technically, note that $i$ is defined to account for the fact that some towns cross county borders (see appendix for more details) and some towns are not in Census data.

${ }^{11}$ Note that monthly or even annual population data did not become available until the release of the five year ACS data and as a result, to update populations, I would need to linearly interpolate population numbers between 2000 and 2010. Such an exercise is entirely possible, but holding the population fixed at either 2000 or 2010 does not seem to make a difference in the rates; linear interpolation at the monthly frequency would move the numbers at the end years the same amount and as a result, the across year changes would be even more miniscule.
} 
the total tax rate in the state is given by:

$$
\bar{\Omega}_{k, t}=\zeta_{k, t}+\frac{\sum_{i \in \Theta_{k}}\left(\tau_{i, k, t}+\delta_{i, k, t}+T_{i, k, t}\right) p_{i}}{\sum_{i \in \Theta_{k}} p_{i}},
$$

and where it is easy to see that the aggregated measure of all local option sales taxes within a state is simply equal to $\bar{\Omega}_{k, t}-\zeta_{k, t}$. In the attached tables, I report $\bar{\Omega}_{k, t}$ and each of the disaggregated measures of local, district and county statistics. Notice that because population varies within a county, equation 3 is preferred to simply adding $\overline{T_{k, t}}$ and $\tau_{k, t}^{-}$. I always report the statistics for December of each year in the data set.

I addition to statistics on the population weighted aggregates, measures of dispersion of the data across a state are also useful information. Because most studies of LOST are within a state, we do not know what factors - institutional, economic, or political - drive differences in the variation of LOST rates within a state. Simple scatter plots using a regression discontinuity design in Agrawal (forthcoming) suggest that the standard deviation and the range of LOST are higher in low-tax states than in high-tax states. I also calculated weighted measures of the standard deviation: ${ }^{12}$ The variance of municipal rates within a state is give by

$$
\operatorname{Var}\left(\tau_{i, k, t}\right)=E\left[\tau_{i, k, t}-E\left(\tau_{i, k, t}\right)\right]^{2}
$$

where the expected value $E\left(\tau_{i, k, t}\right)$ is given by equation 1 . The sample analog of this equation for each state is estimated as

$$
\hat{\operatorname{Var}}\left(\tau_{i, k, t}\right)=\frac{\sum_{i \in \Theta_{k}} p_{i}\left(\tau_{i, k, t}-\tau_{k, t}^{-}\right)^{2}}{\left(\sum_{i \in \Theta_{k}} p_{i}\right)-\frac{1}{\sum_{i \in \Theta_{k}} p_{i}}\left(\sum_{i \in \Theta_{k}} p_{i}^{2}\right)}
$$

where the second term in the denominator denotes the bias correction term derived in the appendix. I report the standard deviation instead of the variance. Similar sample analogs can be defined for all of the other tax rates.

Tables 1 to 2 show above statistics across states for December 2003 and December 2011 using 2010 population weights. Tables for the years in between are all reported in the appendix. In the appendix, table 7 shows the results using 2000 populations as weights and table 8 shows unweighted results. The results are extremely similar; for example, the

\footnotetext{
${ }^{12}$ Unweighted measures are also available from the author.
} 
national weighted average local tax rate differs only by .002 percentage points. As such, I will proceed using 2010 population weights. The population weighted total sub-state tax rate in 2011 was 1.5 percentage points and this value includes zeros for observations where localities are prohibited from implementing LOST. This implies a $30 \%$ increase in addition to the average state tax rate. The standard deviation of this number is 1.49 . There is substantial variation across the states. For example, in 2011 Virginia and Mississippi had only one town each utilizing local sales taxes; in West Virginia, the first local rate appeared in 2011. At the opposite extreme is a state like Louisiana where the local tax rate is 4.67 relative to a state rate of only 4 percentage points. New York is in a similar situation where the local rate is 4.48 relative to a four percentage point state rate.

\section{Documenting Facts and Trends of LOST}

\subsection{The Time Series National Patterns of LOST}

National revenue data indicate that localities have been shifting away from the property tax. At the same time, revenue from local sales tax rates has increased as a fraction of municipal own-source revenue. Figures 1 to 3 document the time series properties of the data for states with local taxes at one or more levels of government. ${ }^{13}$ Figure 1 shows that these increases in revenue are accompanied by gradual increase in local sales tax rates over time. Excluding non-LOST states shows an increase in level terms of the total local sales tax rate given by $\bar{\Omega}_{k, t}-\zeta_{k, t}$ from 1.59 to 1.82 . Of the various types of local tax rates, county tax rates have risen $10 \%$, city tax rates have risen $14 \%$, and district tax rates have become more popular and have risen $27 \%$ relative to their initial values in 2003 . This corresponds to $0.10,0.09$, and 0.04 percentage point changes in county, town, and district tax rates when using only states with LOST (and a 0.08, 0.08 and 0.03 change if using all states). The population weighted state tax rate has risen $1.4 \%$ of its initial value or 0.08 percentage points. Including more than 15 states that do not allow for LOST, the total local sales tax rate has risen from 1.29 to 1.48 , which corresponds to a $14 \%$ change over the time period. State rates increased by 0.16 percentage points, which is $3 \%$ of the initial value. Thus, although state tax rates in level terms have risen by a slightly large amount, the growth rate in municipal taxes has been more rapid. This leads to the first fact.

Fact 1. Local sales tax rates have increased over the last decade. The change of local sales tax rates - driven mostly by increases in county and town tax rates - has exceeded the change

\footnotetext{
${ }^{13}$ The first two figures of the appendix show the same weighted averages for all states - including states that do not allow for LOST.
} 
in state tax rates.

One noteworthy event is the spike in state-level tax rates after the Great Recession, but not local rates. From Figure 1 it is also noticeable that the growth in LOST has slowed in recent years. In an effort to study the how LOST has grown over time, figure 2 plots the percent change in the total local tax rate - defined as the difference of the natural logarithm of the tax rate minus the natural logarithm of the lagged tax rate. Immediately noticeable from this figure is the fact that the percent change in LOST is usually positive.

Fact 2. Local sales tax rates have been more stable in the months following the Great Recession than they were prior to or during the recession.

The average monthly percentage change in total local tax rates in the period prior to the end of the Great Recession was $.17 \%$ but it fell to .04\% in the period following the end of the Great Recession. A simple test of the difference in group means rejects the hypothesis that the percentage changes are the same (with a p-value of .006). Such a result is surprising in light of conceivable increases of revenue demands on municipal governments following the recessionary period. However, it is consistent with a view where local sales tax rate increases are less politically feasible in periods when income and spending are relatively low and may also be consistent with the rise of online shopping. The results suggests that local sales tax changes may be driven by the economic climate or the business cycle.

Although taxes have risen over the sample period, one may wonder what has happened to the overall dispersion of tax rates in the economy. Using the population weighted standard deviations as defined in equation 5, I calculate a similar statistic at the national level over the course of the complete time series for the data. Figure 3 shows how the population weighted standard deviation of LOST has changed over time. The results are dramatic - the dispersion of the distribution of local tax rates - has increased consistently and dramatically overtime.

Fact 3. The dispersion of local sales tax rates has increased over time. The dispersion in county and city tax rates increased at the same rate.

When using only states with LOST, the standard deviation of the total local rate increased $9 \%$ due to an $4 \%, 9.5 \%$ and $26 \%$ change in the standard deviation of county, town and district taxes, respectively. Using all states, the standard deviation in the total local tax rate has increased by about $9 \%$ from its initial value in 2003. Of the individual components, the standard deviation of city rates increased $9.8 \%$ while the dispersion of county tax rates increased by $4.8 \%$. For district taxes, the dispersion decreased by about $26 \%$. The dramatic increase in the population weighted dispersion of local sales tax rates could be driven by two 
factors: (1) jurisdictions electing to change their tax rates may already be in the extreme upper tail of the distribution of tax rates or (2) jurisdictions electing to change their tax rates are only slightly above average but that they are relatively large jurisdictions. In the subsequent sections I will explore these two possibilities.

\subsection{Changes Over Time Across States}

In the next set of figures, I document the relationship of changes over time from 2003 to 2011 with a particular attention to initial conditions and fiscal federalism relationships. For purposes of these sections, I use the state level aggregates displayed in tables 1 to 2 . Figure 4 shows the relationship between local tax rates and state tax rates in 2003 and 2011. Local tax rates are higher in low-tax states than they are in high-tax states. This confirms the regression discontinuity results in Agrawal (forthcoming). The difference from Agrawal (forthcoming) is that the population weighted average tax rate is higher for the state as a whole in low-tax states and the results of figure 4 represent a simple correlation; Agrawal (forthcoming) uses a regression discontinuity design and therefore can only draw inference about local tax rate disparities near the border. A simple univariate regression indicates that for each percentage point increase in the state tax rate, the average local tax rate is 0.64 percentage points lower. ${ }^{14}$ This relationship has become more intense over time and is economically significant.

Fact 4. Local tax rates are higher in low-tax states than local tax rates in high-tax states.

Figure 5 shows a strong a statistically significant relationship between the standard deviation of local sales tax rates and the state tax rate; the right panel shows its relationship with the average local tax rate in the state. Not only do states with low state tax rates set higher tax rates, but they also have a greater degree of dispersion in their local rates. In the highest tax states, the standard deviation of local tax rates is less than 0.5 , but in the lowest tax state it is over 1 . However, over time, this negative relationship between the state tax rate and the dispersion of local sales tax rates has become less intense. This suggests that the dispersion has increased more-so in relatively high-tax states. This could be a result of a number of reasons including the presence of statutory maximums on LOST, which are most likely to bind in states where LOST are already relatively high - and in fact, past studies have found that "maxing out" is common in these states. The right panel shows that the standard deviation of LOST are highest in states where the average LOST rate is highest. This results taken together with the left panel of Figure 5 is consistent with Fact 4 .

\footnotetext{
${ }^{14} \mathrm{All}$ of the results in this section use a simple univariate regression using across state variation to determine correlations in the data. None of the coefficients on these equations should be viewed as causal effects.
} 
Fact 5. The dispersion of local sales tax rates is greatest in states with low-sales tax rates at the state level and in states with high average local tax rates, but this relationship is weak.

In figure 6, I demonstrate a insignificant relationship between tax rates and initial conditions and changes over time. Local tax rate changes are only weakly related to the initial level of the state tax rate. Similarly, the relationship between the change in the average local tax rate for each state from 2003 to 2011 is only weakly related to the change in the state tax rate over this same time period. In both graphs, the effects are negative, which suggests that localities will offset the policies of higher levels of government over the long-run. Figure 7 studies the change in the standard deviation from 2003 to 2011. Dispersion has weakly increased the most in states with initially high state tax rates. More pronounced, is the second panel of this figure, which shows a strong and significant positive relationship between the change in the standard deviation and the change in the average tax rate. In states where the average tax rate increases the most, the standard deviation also increases more intensely. For each percentage point increase in the average local tax rate in a state, the standard deviation rises by 0.29 .

Fact 6. The dispersion of local sales tax rates has increased the most in states where local tax rates increased the most.

Finally, figure 8 shows the relationship between the changes (2003 to 2011) of various tax rates with other levels of local government in the federalist hierarchy. The results indicate that in states where county tax rates rose, municipal tax rates fell, although the relationship is statistically insignificant. In states where municipal tax rates rose, district taxes also fell. No discernible relationship between district and county tax rates exists, possibly a result of the fact that in some states districts are coterminous with county borders, while in other states districts are sub-municipal.

Fact 7 . Changes in municipal tax rates and changes in district tax rates are negatively related. The relationship between changes in the town tax rate and county tax rate is negative, but insignificant.

\subsection{The High-Frequency Dynamics of Changes}

Up until now, we know relatively little concerning the dynamics of tax competition. ${ }^{15}$ How frequently do jurisdictions change their tax rates? Are tax rates sticky? When they do change their rates are they more likely to pass a small marginal change or a dramatic change? What

\footnotetext{
${ }^{15}$ Dynamic responses to fiscal policy have been the subject of theoretical work, notably Wildasin (2011).
} 
types of jurisdictions are more likely to change their rates? Studies such as Sjoquist et al. (2007) answer similar questions for the state of Georgia; however, state based institutional features of LOST make it difficult to then generalize the information about Georgia local tax rates to the nation as a whole. This is the first study to analyze the frequency of LOST changes at the national level.

Figure 9 shows the frequency of state tax changes by month along with the average size of the state tax change. As was noted already, the overall trend in state tax rates was upward over this time period. Tax rate changes often occur on round increments such as one percentage point. More interesting, are the subsequent graphs of the dynamics of county and town tax rates.

Figure 10 shows the number of county tax rate changes over time and the average size of tax rate changes. When constructing this figure I use only county tax rate changes that affect the entire county. In some states, county sales tax rates may change differently in incorporated and unincorporated areas of the county; these type of changes are excluded such that I only use changes that affect all matched and unincorporated areas in a county. Thus, the number of county tax rate changes represents a lower bound on the true changes. What is noticeable is that increases dominate the number of decreases. Figure 11 shows the number of people and towns exposed to tax rate changes. For ease of interpretation, in these graphs, I omit a few months where the total population of a county changing its rate was greater than 2 million people - for example, the month where Clark County, Nevada changes its tax rate. ${ }^{16}$

Over the course of the sample, 959 county tax changes occur of which approximately $35 \%$ are decreases; the total number of counties in states allowing for county sales taxes is approximately 1650. Of these changes, a small fraction include counties that change their tax rate more than once. The average tax change was an increase of .19 percentage points. The average county tax rate in states with county taxes was 1.70 in 2011 . In an average month, 770,000 people are exposed to a county tax decrease while 900,000 people are exposed to a county tax increases. On average, the sizes of the jurisdictions changing their tax rates are relatively large - having an average population of over 120,000 and a median population of approximately $65,000 .{ }^{17}$ Furthermore, the final panel shows that a large number of towns are affected by county tax changes. In an average month, 32 towns are exposed to a county

\footnotetext{
${ }^{16}$ Including this observation skews the axis so much that the variation at smaller population levels cannot be seen. I will make similar exclusions for the graphs at the town levels. All summary statistics in the table and text include all observations. These large values are only excluded in the figures where they mask the variation over time.

${ }^{17}$ In 2010, the average county in the United States was 97,000 people while the median contained 22,000 people.
} 
tax rate decrease, while 59 towns are exposed to a county tax increase. The numbers are largest when state level institutional reforms make it so that many or all counties within the state can easily change their tax rates. This has implications for vertical tax competition.

Fact 8. Over the period 2003 to 2011 approximately $25 \%$ of towns in states with LOST change their municipal tax rate. Approximately 2/3 of counties change their tax rates over the same period. Approximately $35 \%$ of county tax rate changes are decreases in the tax rate and approximately $20 \%$ of town tax rate changes are decreases.

Figures 12 and 13 show similar statistics at the town level. In all of these statistics each matched Census place remains one observation; for non-matched Census places, remember that they appear as one average tax rate for the residual population. If this average changes, I count it as one change. ${ }^{18}$ Over the course of the sample (100 months), there are 4877 town tax changes, of which $20 \%$ are decreases. There are 18,765 Census places in America that are in states allowing for LOST. The average tax change was 0.39 percentage points and the weighted average local sales tax rate in 2011 was 0.88 among states allowing towns to set these rates. Approximately 165,000 people are exposed to a town tax decrease in the average month, while 590,000 are exposed to a tax increase in the average month. The average size of a jurisdiction that increases its tax rate is approximately 15,000 people with a median of 7300 people in towns. Again these jurisdictions are bigger than the average jurisdiction in America. ${ }^{19}$

Fact 9. Although the number of tax rate changes is relatively small, tax rate changes disproportionately occur in large towns and counties, which implies that a large fraction of the United States population gets exposed to changes in LOST in a given year.

Figure 14 tries to see if there is a relationship between the level of the tax rate in the period prior to the change and whether or not a jurisdiction changes its tax rate. What is immediately noticeable is that jurisdictions lowering their tax rate have a much more disperse pattern of rates. Prior to a tax change in the county tax rate, the average (unweighted) county rate was 2.07 in places that subsequently lowered their rate and 1.02 in counties that raised their rate. In towns, the (unweighted) average tax rate prior to a decrease was 1.37; the average tax rate prior to an increase was 0.56. Table 3 summarizes all of the change dynamics by state. North Carolina has frequently changed its state sales tax rate over this time period. Relative to the number of jurisdictions in the state, county tax rate changes

\footnotetext{
${ }^{18}$ This average may change because one or more unmatched town changes its rate. Thus, these numbers represent lower bounds on the total number of changes. The results are robust to excluding these observations.

${ }^{19}$ The average Census place has 8000 people and the median has just over 1000 people.
} 
are most frequent in states such as Oklahoma and Wyoming. Town tax rate changes are most frequent in New Mexico, Missouri, and Washington.

Finally figure 15 shows the relationship between the size of tax rate changes and initial tax rates. At the town level, the size of the tax rate change is not at all related to the lagged tax rate in the jurisdiction, but is related at the county level. However, there is a strong negative relationship between the size of the change in the town tax rate and the contemporaneous change in the county tax rate that the town is within. Given the strength of this relationship, this suggests that towns and counties may coordinate their policies this may be a result of tax rates going into effect in both jurisdictions at the end of the fiscal year or may be a result of coordinated ballot initiatives to pass local sales tax rate. What is most noticeable is that among towns that increase their tax rate almost none of these towns are located in counties that contemporaneously lowered their tax rate. Amongst towns that lower their tax rate, the division is less clear. Towns with large decreases in their tax rates are clustered in the right quadrant, but for smaller tax rate changes, the pattern begins to blur.

Fact 10. When towns lower their tax rate, counties often contemporaneously increase their tax rate; when towns increase their tax rate, counties decrease their tax rate.

\section{An Application to Tax Competition}

In the above sections, I presented evidence on the time series properties of the data. In this section, I present evidence on spatial patterns in the data and demonstrate that the strength of spatial autocorrelation in the data is sensitive to the inclusion of local sales tax data.

\subsection{Spatial Patterns of the Data}

The formulas used to construct measures of the population weighted tax rates at the state level can be modified to construct weighted averages of local taxes at the county level. After doing so, I calculate the change in the population weighted average local tax rate for every county in the country for 2011 and 2003. I then calculate the change in these weighted measures over this time period. After mapping this data, spatial patterns begin to emerge. Figures 16 and 17 show changes in state tax rates and changes in the total tax rate (inclusive of LOST) at the county level. The appendix includes four additional maps that show the spatial arrangement of district, county, town and total LOST rates separately.

Changes in state tax rates appear to be clustered in the northeast, mid-Atlantic states,

and southwestern states with some other scattered changes in the midwest and plains. Figure 
17 shows that changes in the total tax rate vary both across and within states. In some states the variation in the size of changes within a state are quite similar (for example, Virginia and North Carolina). In the case of Virginia, the change was driven by a state reform with little change at the local level. One reason for this is that Virginia is a strong Dillon's Rule state. In Virginia, if local authority is not explicitly granted to sub-state governments, then it is assumed not to exist. In fact, in Virginia, local sales tax changes are voted on by the state legislature. Effective July 2014, the state passed a 0.70 additional county sales tax for all cities and counties within Northern Virginia and the Hampton Roads Region. Similarly, historical experiences in North Carolina - specifically, many local government going bankrupt in the Great Depression - have shifted power away from localities to the state government. As such, spatial correlation within a state need not be evidence of tax competition; rather it may simply be evidence that the state government has strong control over its local governments.

Other states such as Alabama, Louisiana, Missouri, Oklahoma, and Colorado show a high degree of variation within a state. These states allow localities much more autonomy when setting LOST compared to Virginia and North Carolina. Within states some clustering begins to emerge. For example, the largest decreases are in northeastern Utah and several contiguous counties in south eastern Colorado. Across states, similarities also exist. Border counties in Arizona and New Mexico both saw increases. Border counties in Oklahoma and Arkansas saw increases. The same is true of three of the four states bordering Minnesota. This ocular evidence seems to suggest that spatial correlation of tax changes may persist across state borders.

\subsection{An Introduction to Spatial Relationships}

Following the work of Case, Hines and Rosen (1993), several empirical studies, have studied tax competition across states. ${ }^{20}$ I use the aggregate statistics by month that I have created to study spatial tax competition across states. In order to accurately measure the strategic interactions across governments of the same level, the researcher must also account for vertical strategic interactions. Vertical strategic interactions occur when different levels of government that cohabit the same tax base have tax setting authority. Omission of the vertical interactions may bias horizontal strategic interactions (Besley and Rosen 1998). Studies of tax competition at the state level often lack information on tax rates at the local level within a state. Going forward, I propose using the population weighted local tax rates within a state to estimate the strategic interactions across states. Of course, when a state

\footnotetext{
${ }^{20}$ For excellent summaries, please see Brueckner (2003) and Revelli (2012).
} 
is composed of many localities, how to weight the local tax rates within a state may be a matter of debate. Arguably, state governments pay much more attention to the largest cities (places with the largest tax bases) when responding to municipal governments. Thus, the population weighted averages constructed in this paper are a natural starting point. Maximum likelihood methods are used to address endogeneity concerns.

Relatively few studies of tax rates employ spatial and temporal variation to identify tax competition. Thus, before proceeding, I summarize the most general form of a spatial econometric model to test for spatial correlations using panel data. Consider a world with $N$ states; let $i$ index a state, let $j$ index neighbors, $t$ index time, and let $k$ index possible control variables denoted $x$. A general specification for panel data can be written as

$$
\tau_{i t}=\alpha+\delta \tau_{i t-1}+\rho \sum_{j=1}^{N} w_{i j} \tau_{i t}+\sum_{k=1}^{K} x_{i t k} \beta_{k}+\sum_{k=1}^{K} \sum_{j=1}^{N} w_{i j} x_{j t k} \mu_{k}+\zeta_{i}+\gamma_{t}+\lambda \sum_{j=1}^{N} w_{i j} v_{i t}+\varepsilon_{i t}
$$

where $\tau$ is a measure of the the tax rate in state $i$ at time $t$; I run several different specifications using the state-level rate and the total rate inclusive of local taxes. Notice that equation 6 includes the time lagged dependent variable to address the fact that current tax rates are heavily dependent on previous values; state fixed effects $\left(\zeta_{i}\right)$ and time dummies $\left(\gamma_{t}\right)$ are also included. To allow for strategic interactions across space, a spatial lag $\sum_{j=1}^{N} w_{i j} \tau_{i j}$ is included where $w_{i j}$ is the weight that neighboring state $j$ is given. Following the literature, I restrict $\sum_{j=1}^{N} w_{i j}=1$ for each state $i$. Notice that the term with the double summation allows for weighted averages of your neighbors' control variables $(x)$ to influence your own tax rate. Until recently, these variables were often excluded from the regressions, but recent work such as LeSage and Pace (2009) and Elhorst (2010) suggest including them. Notice that in the presence of fiscal federalism and a state level dependent variable, one of the $x$ controls should always include taxes at lower levels of government. This represents the first study to study across state strategic interactions while also controlling for the local tax rates within the state as well as within the neighboring state. And $v$ is an error that has a spatial process.

Of course, the choice of weights $w_{i j}$ merits some discussion. For purposes of this paper, I will use a measure of contiguity. Often times, contiguity is used to define neighborliness across jurisdictions and when using contiguity weights each neighboring state is given equal weight. As an example, consider the state of Connecticut, which has three neighbors. As such, the weights given to New York, Massachusetts, and Rhode Island would be 1/3 each. For the case of sales tax rates, contiguity seems to be a reasonable criterion given that states are worried about cross-border shopping. Unlike the case of cigarettes, smuggling of retail 
sales goods is not organized and usually only occurs across neighboring state borders. More formally, I can define the weights as

$$
w_{i j}=\left\{\begin{array}{cc}
\frac{1}{m_{i}} & \text { if } j \in M_{i} \\
0 & \text { if } j \notin M_{i}
\end{array}\right.
$$

where $M_{i}$ is the set of towns contiguous to state $i$ and where $m_{i}$ is the number of towns in $M_{i}$.

Before proceeding, I need to note variants of equation 6 used in the literature. When $\lambda=0$, the model is a spatial Durbin model (SDM). The spatial Durbin model is advocated by LeSage and Pace (2009), Elhorst (2010) and Revelli (2012). Because neighboring jurisdiction's covariates enter directly into the regression, it is the more general specification. If $\mu_{k}=0$, then the model is usually referred to as a spatial auto-regressive model with autoregressive disturbances (SAC). This is also known as the Kelejian and Prucha (1998) model. If $\lambda=0$ and $\mu_{k}=0$, the model is a spatial auto-regressive model or spatial lag (SAR). If $\mu_{k}=0$ and $\rho=0$, it is a spatial error model (SEM). Note further that when the model has $\delta=0$ it is static; when the model has $\delta \neq 0$, it is a dynamic model (Yu, de Jong and Lee 2008). In what follows, I estimate equation 6 using maximum likelihood methods and wish to make the point that when we consider tax competition, we can consider competition more broadly than states choosing their state tax rate. In the results that follow, I will use the spatial Durbin Model. The main advantage of a spatial Durbin Model is that it is less restrictive; furthermore, it produces unbiased coefficient estimates if the true underlying process is a spatial lag or a spatial error model (Elhorst 2010).

The results of this model should be interpreted with caution. Identifying tax competition as the causal channel through which spatial patterns arise can be difficult (McMillen 2010, Gibbons and Overman (2012)). In the most cautionary case, parameter estimate from equation 6 are simply informative of spatial autocorrelation in the tax rates because unobservable correlated shocks may hit contiguous jurisdictions. Recent developments suggest, in order to make statements that these spatial correlations are evidence of tax competition, studies must construct a more quasi-experimental design (Agrawal (forthcoming), Eugster and Parchet (2011), and Lyytikäinen (2012)). Thus, the purpose of this section is designed to show that a researcher without access to local data - using a standard reduced form reaction functions estimated in the literature - will obtained biased estimates of the association between one state's tax rate and its neighboring states' tax rates. As such, the estimates below should be view as rigorous spatial associations which are suggestive of tax competition and these estimates help to provide geo-spatial descriptive statistics designed to be complementary to 
the time series statistics. When using the total effective local rate, these associations represent spatial relationships of the local tax systems across states; when using the state sales tax rate, they represent only the relationship with neighboring state tax rates. At the same time, I would argue that the high-frequency panel data used in this paper and the aggregation of local tax rates to the state level helps to address the concerns of McMillen (2010) and Gibbons and Overman (2012). As such, the threat to identification are high-frequency spatially correlated shocks across states. If such shocks are uncommon, then the equation can be interpreted as a reduced form reaction function and the spatial relationships can be directly interpreted as tax competition.

\subsection{Motivation: Spatial Patterns in the Total Rate}

Traditionally, it is assumed that states select their state tax rate in competition with other states. Researchers control for the tax rates of other levels of government within the state if the data are available. But, what if states do not choose the state tax rate, but rather the total (state plus local tax rate)? In the U.S. Supreme Court ruling Clinton v. Cedar Rapids and the Missouri River Railroad, the Court wrote that "Municipal corporations owe their origin to, and derive their powers and rights wholly from, the legislature. It breathes into them the breath of life, without which they cannot exist. As it creates, so may it destroy. If it may destroy, it may abridge and control." This principle has become known as Dillon's Rule - that municipalities are creatures of the state. ${ }^{21}$ I raise the principle underlying Dillon's Rule to simply motivate the premise that although most state governments do not dictate the level of LOST rates, they do control whether or not municipalities and counties are allowed to set local tax rates; other state restrictions on LOST also may implicitly dictate the level of local rates in the state. The intuition extends beyond Dillon's Rule to the general idea that municipal authority and autonomy can vary across states and jurisdictions, in part because of choices made by the state.

Furthermore, as noted in a previous section, states may impose restrictions on municipal taxing authority by setting statutory tax minimums and maximums. States may delegate taxation to one, two, or three levels of government. States may dictate the terms by which municipalities can increase their rates (whether they must follow particular increments or whether local tax rates must sunset). States determine the political procedures by which localities must pass local option sales taxes - perhaps making it more difficult to do so if they want to constrain their municipalities. Many of these components will in turn be reflected

\footnotetext{
${ }^{21}$ For legal discussion of Dillon's Rule and the authority of local governments more generally, please see Cohn (1957), Schragger (2001), and Schragger (2006). The appendix highlights relevant portions of these legal articles for economists.
} 
in the level of the statutory tax rate set by municipalities. In states with restrictive LOST systems, local rates will likely be lower than in states with flexible systems, all else equal. This result is not because the municipality has a desire to set a competitively low rate, but rather because the state in competition with other states has implicitly dictated that the rate must be low. Some elements of the tax system - such as enforcement differences and tax base differences - are not observed. Thus, the weighted average of local plus state tax rates is only an imperfect gauge of the true effective local tax rate that the state desires within its borders.

Although municipalities have freedom to choose their tax rates, they do so in an environment that is dictated by the state government. Through these constraints, states can dictate whether or not the average municipal tax rate in a state will be high or low - or in states that prohibit LOST, that it will be zero. This would suggest that a state is not only picking its state tax rate in competition with its neighbors, but rather, its total effective tax rate for an average consumer in its state. If so, then the researcher should study state competition over the the components of the local rate rather than the state rate in isolation. One advantage of this procedure is that it allows the researcher to then estimate a spatial equation that does not include vertical strategic interactions. A second advantage is that using the total rate rather than the state rate and the local rate separately allows for the researcher to account for other institutional aspects discussed above when estimating spatial associations in the data. I will present this alternative specification in addition to reaction function equations that control for local tax rates separately.

\subsection{Results}

Exploiting the high frequency nature of the panel means that relatively few control variables will be tracked at the monthly frequency. In addition to state fixed effects and month fixed effects, some control variables are tracked at the monthly frequency by the Bureau of Labor Statistics (BLS). In some specifications, I include the monthly unemployment rate of each state and the log of the size of the labor force. Furthermore, in some specifications I also include variables at the annual frequency from the American Community Survey (ACS). Unfortunately, the ACS one year estimates start in 2006, so any specifications using ACS data will need to drop 28 months of the 100 months of data. Descriptive statistics of all control variables included in the estimating equation are detailed in table 16 . I estimate the spatial panel using maximum likelihood techniques. I present results using the weighted average of local tax rates within a state created in this paper at the monthly frequency. Appendix table 17 reports results using a simple unweighted average of the local tax rates 
within a state.

Table 4 reports the results of estimating equation 6 giving equal weight to each state and giving more weight to larger population states. I present two sets of comparisons: (1) the dependent variable is the statutory state sales tax rate and (2) the dependent variable is the total tax rate for the average person in the state, which is equal to the state tax rate plus the weighted average local tax rate in the state. I use the data at the monthly frequency. All estimating equations include a spatial lag of the dependent variables, the control variables discussed above, and the weighted average of the neighbors control variables (the spatial Durbin model). When using the statutory sales tax rate as the dependent variables, I control for the average local tax rate in some specifications. Use of the statutory sales tax rate is the conventional dependent variable in the literature. In alternative specifications, when I use the total effective tax rate in the state, I take the view that states choose their state tax rate as well as the average local tax rate in the state (by effectively setting legal restrictions on the degree of autonomy that the state grants to the localities). In this second view, their is no need to control for the tax rates of other levels of government, as the state internalizes them - and as such, the only tax variable on the right hand side of the estimating equation is the spatial lag of total rate.

The coefficient of interest is $\rho$, which determines the intensity of the spatial associations of tax rates across of states. If the coefficient is positive, a decrease in your neighbors' tax rate implies that your tax rate will also fall. Looking at columns (1) and (2), a one percentage point increase in neighbor's state tax rate implies a 0.10 percentage point (contemporaneous) increase in the own state tax rate. Adding ACS demographic and population controls does not change the point estimates at all. Given the high frequency nature of the data, this suggest that the time dummies are doing a good job controlling for other variables. In column (2'), I control for the average local tax rate within the state as well as the average local tax rate in neighboring states, which would be necessary if diagonal strategic interactions across governments are important. The coefficient falls to 0.072. In specification (2'), tax rates at other levels of government may very well be endogenous. A tax system perspective circumvents this issue because in the tax system perspective, it is assumed that the state essentially competes over the total tax burden and that the locality is simply a creature of the state.

In column (3), I look for competition in the total tax rate across states. The coefficient on the spatial lag is quite similar to the value of $\rho$ in specification (2'). A one percentage point increase in the neighbor's total state plus average local tax rate raises the total own tax rate by 0.068 percentage points. The significance of this variable suggests that states do account for the tax system as a whole - there are significant spatial relationships with the state tax 
rate in the neighboring state in addition to other dimensions such as whether their neighbors allow for LOST and how flexible neighboring states allow LOST to be. The coefficient is smaller in this context than when using the state tax rate. One explanation for this is that the model only identifies the contemporaneous strategic interactions. The coefficient remains strongly significant which suggests that states are similar to their neighbors both in their state tax rates and in their tax system as a whole, which then suggests looking at the various local tax system separately.

Table 5 test this more directly by studying the relationship between the average total local tax rate in a state with that of its contiguous neighbors. Here the coefficient on the spatial lag is intensely large and positive. Keep in mind that this specification regresses the average local tax rate in a state on the average local tax rate of the neighboring states; the regression is not identifying spatial relationships within a state. Despite the fact that states are large geographically, nearby states are surprisingly similar with respect to their average local tax rate. The results is especially surprising given that local taxes in low-state tax states are higher than local taxes in relatively high-state tax neighboring states. Because states are large and many localities are away from borders, the implication is that the strategic interaction is not simply picking up stronger tax mimicking among border jurisdictions on either side of state boundaries. Furthermore, we can break down the relationships across various types of local taxes. Table 5 hows that the relationship is more intense for some tax instruments than others; however, the sum of the spatial lag coefficients across county, towns, and districts is smaller than the spatial lag regression using the sum of the tax rates. This suggests that it is the local tax system as a whole that exhibits more spatial association with neighboring states than any one particular component of the local tax systems. This suggests that states elect to set similar institutional rules governing LOST. Consider the simple decision of whether to allow for LOST or not: states not allowing for LOST are concentrated in particular geographic regions. Other institutional features are also likely to be geographically persistent. For this reason, this provides powerful evidence of spatial correlation in the tax system as a whole.

This section has shown that aggregate indexes of LOST rates within a state are important to estimating the strategic interactions of states. At a minimum they act as an effective control (as in 2') allowing the researcher to more accurately measure the horizontal spatial relationships in the state tax rates. At their best, they allow the researcher to make broader conclusions about how states interact strategically from a tax system perspective where local governments are creatures of the state. Furthermore, the results of this model descriptively suggest that the time series patterns documented in the previous sections of the paper are more spatially correlated than if they changes as a result of a random process. 
Beyond tax competition, use of the indexes constructed in this paper will prove fruitful to study questions concerning firm location decisions, behavioral responses to taxes, and tax incidence. Consider tax incidence as an example. Currently, in a general sense, we regress pre-tax prices on a variety of controls and the sales tax rate. We would like that sales tax rate to include local taxes, but until now, that has not really been possible beyond using subsamples of urban areas. So, in actuality, the sales tax rate in these regressions in generally the statutory state sales tax rate. The coefficient estimate on the sales tax rate will then be missing the covariance between the local rates and pre-tax prices, the variance of local rates, and the covariance of state and local rates. The estimates of the regression model above (column (2') - the coefficient on local tax rates) and my own previous work imply that the covariance between state rates and local rates is negative. In future work, I hope authors can use the series generated in the paper to shed light on the covariance between local rates and pre-tax prices; in doing so, we can reduce the bias in our estimates of tax incidence. Other extensions abound.

\section{Conclusion}

A national panel of local sales tax rates has eluded researchers - despite its importance to answering fundamental public and urban economics questions. The assembly of such a panel is extremely time intensive; researchers need to contact individual states and sometimes even counties in order to assemble the data. Even in the context of the proprietary data in this study, cleaning the data is time intensive in order to accurately account for boundary changes, jurisdiction name changes, and possible erroneous values in tax rates. Although the data are proprietary and specific local tax rates cannot be disclosed, I have done my best to assemble a panel data set at the monthly frequency and at the state level that explicitly details the population weighted average of the state, town, county, and district taxes in all states plus the District of Columbia. This data should be useful to researchers who (1) seek to more accurately measure the average tax differential at state borders, (2) wish to more accurately measure state variation in tax policy over time and across states, (3) desire to create more accurate price indexes that included state and local tax rate burdens, and (4) to better understand the time paths and dynamics of local tax setting behavior and competition.

In the absence of this data, researchers were unable (at the national level) to determine how frequently local sales tax rates change, how states differ in the levels of variation of their local sales tax rates, and little was known about the time series properties of LOST in America. This study documents ten stylized facts that provide researchers with ample new 
puzzles and questions. Future research may consider question such as the following. Why is the frequency of LOST changes (perhaps) more rigid that expected? Why have taxes increased faster at some levels of government to others? What is the role of the business cycle in LOST decision making? How can we think about tax systems in the context of tax competition? How do the institutional features across states affect tax competition? Does accounting for local sales tax rates change the estimates of the behavioral responses or tax incidence that we have estimated in the past using only state tax rates or a sub-sample of towns? These and many more questions arise from a first look at national panel data on LOST. In documenting the facts, this study has in some sense raised more questions - and hopefully spurred interest in using "big data" at the municipal level to answer these central public and urban economics questions.

\section{References}

Agrawal, David R. 2011. "The Tax Gradient: Do Local Sales Taxes Reduce Tax Differentials at State Borders?" Working Paper, University of Michigan.

Agrawal, David R. 2013a. "Inter-federation Competition: Sales Tax Externalities with Multiple Federations." WorkingPaper, University of Georgia.

Agrawal, David R. 2013b. "The Internet as a Tax Haven?: The Effect of the Internet on Tax Competition." University of Georgia Working Paper.

Agrawal, David R. 2013c. "Over the Borderline: How the Characteristics of Lines Shape Optimal Tax Policy." Economics Letters, 119(2): 113-116.

Agrawal, David R. forthcoming. "The Tax Gradient: Spatial Aspects of Fiscal Competition." American Economic Journal: Economic Policy.

Albouy, David Y. 2012. "Are Big Cities Bad Places to Live? Estimating Quality of Life across Metropolitan Areas." Working Paper.

Ballard, Charles L., and Jaimin Lee. 2007. "Internet Purchases, Cross-Border Shopping, and Sales Taxes." National Tax Journal, 55(4): 711-725.

Baum-Snow, Nathaniel, and Ronni Pavan. 2012. "Understanding the City Size Wage Gap." Review of Economic Studies, 79(1): 88-127.

Benjamin, Daniel K., and William R. Dougan. 1997. "Efficient Excise Taxation: The Evidence from Cigarettes." Journal of Law and Economics, 40(1): 113-136. 
Besley, Timothy J., and Harvey S. Rosen. 1998. "Vertical Externalities in Tax Setting: Evidence from Gasoline and Cigarettes." Journal of Public Economics, 70: 383-398.

Besley, Timothy J., and Harvey S. Rosen. 1999. "SalesTaxes and Prices: An Empirical Analysis." National Tax Journal, 52(2): 157-178.

Brueckner, Jan K. 2003. "Strategic Interaction Among Governments: An Overview of Empirical Studies." International Regional Science Review, 26: 175-188.

Burge, Gregory, and Cynthia Rogers. 2011. "Local Option Sales Taxes and Consumer Spending Patterns: Fiscal Interdependence under Multi-tiered Local Taxation." Regional Science and Urban Economics, 41: 46-58.

Burge, Gregory S., and Brian Piper. 2012. "Strategic Fiscal Interdependence: County and Municipal Adoptions of Local Option Sales Taxes." National Tax Journal, 65(2): 387416.

Carrillo, Paul E., Dirk W. Early, and Edgar O. Olsen. 2012. "A Panel of Price Indices for Housing Services, Other Goods and All Goods for All Areas in the United States 1982-2010." Working Paper.

Case, Anne C., James R. Hines, and Harvey S. Rosen. 1993. "Budget Spillovers and Fiscal Policy Interdependence." Journal of Public Economics, 52(3): 285-307.

Cohn, Rubin C. 1957. "Municipal Revenue Powers in the Context of Constitutional Home Rule." Northwestern Law Review, 51(1): 27-42.

Cole, Adam J. 2009. "Christmas in August: Prices and Quantities During Sales Tax Holidays." University of Michigan Working Paper.

Devereux, Michael P., Ben Lockwood, and Michela Redoano. 2007. "Horizontal and Vertical Indirect Tax Competition: Theory and Some Evidence from the USA." Journal of Public Economics, 91: 451-479.

Dumond, J. Michael, Barry T. Hirsch, and David A Macpherson. 1999. "Wage Differentials across Labor Markets and Workers: Does Cost of Living Matter?" Economic Inquiry, 37(4): 4.

Einav, Liran, Dan Knoepfle, Jonathan Levin, and Neel Sundaresan. 2013. "Sales Taxes and Internet Commerce." American Economic Review, forthcoming. 
Elhorst, J. Paul. 2010. "Applied Spatial Econometrics: Raising the Bar." Spatial Economic Analysis, 5(1): 9-28.

Eugster, Beatrix, and Raphäel Parchet. 2011. "Culture and Taxes: Toward Identifying Tax Competition." Working Paper.

Fox, William F. 1986. "Tax Structure and the Location of Economic Activity Along State Borders." National Tax Journal, 39(4): 387-401.

Fox, William F. 2012. "The Oxford Handbook of State and Local Government Finance." , ed. Robert D. Ebel and John E. Petersen, Chapter Retail Sales and Use Taxation, 406-428. Oxford University Press.

Gibbons, Stephen, and Henry G. Overman. 2012. "Mostly Pointless Spatial Econometrics?" Journal of Regional Science, 52: 172-191.

Goolsbee, Austan D. 2000. "In a World Without Borders: The Impact of Taxes on Internet Commerce." Quarterly Journal of Economics, 115(2): 561-576.

Harding, Matthew, Ephraim Leibtag, and Michael Lovenheim. 2012. "The Heterogeneous Geographic and Socioeconomic Incidence of Cigarette Taxes: Evidence from Nielsen Homescan Data." American Economic Journal: Economic Policy, 4(4): 169-198.

Haufler, Andreas. 1996. "Tax Coordination with Different Preferences for Public Goods: Conflict or Harmony of Interest." International Tax and Public Finance, 3(1): 5-28.

Hou, Yilin, and Jason Seligman. 2008. "LOST Stability? Consumption Taxes and the Cyclical Variability of State and Local Revenues."

Hoyt, William. 2001. "Tax Policy Coordination, Vertical Externalities, and Optimal Taxation in a System of Hierarchical Governments." Journal of Urban Economics, 50: 491-516.

Jacobs, Jan P.A.M., Jenny Ligthart, and Hendrik Vrijburg. 2010. "Consumption Tax Competition Among Governments: Evidence from the United States." International Tax and Public Finance, 17: 271-294.

Kanbur, Ravi, and Michael Keen. 1993. "Jeux Sans Frontières: Tax Competition and Tax Coordination When Countries Differ in Size." American Economic Review, 83(4): 877892. 
Kelejian, Harry H., and Ingmar R. Prucha. 1998. "A Generlized Spatial Two-Stage Least Squares Procedure for Estimating a Spatial Autoregressive Model with Autoregressive Disturbances." Journal of Real Estate Finance and Economics, 17: 99-121.

Knight, Brian, and Nathan Schiff. 2012. "Spatial Competition and Cross-border Shopping: Evidence from State Lotteries." American Economic Journal: Economic Policy, 4: 199-229.

LeSage, James, and Robert Kelley Pace. 2009. Introduction to Spatial Econometrics. Boca Raton:Taylor \& Francis.

Luna, LeAnn. 2003. "Local Sales Tax Competition and the Effect on County Governments' Tax Rates and Tax Bases." The Journal of the American Taxation Association, 26(1): 4367.

Luna, LeAnn, Donald J. Bruce, and Richard Hawkins. 2007. "Maxing Out: An Analysis of Local Option Sales Tax Rate Increases." National Tax Journal, LX(1): 45-63.

Lyytikäinen, Teemu. 2012. "Tax Competition among Local Governments: Evidence from a Property Tax Reform in Finland." Journal of Public Economics, 96(7-8): 584-595.

McMillen, Daniel. 2010. "Issues in Spatial Data Analysis." Journal of Regional Science, 50: 119-141.

Mikesell, John L. 1970. "Central Cities and Sales Tax Rate Differentials: The Border City Problem." National Tax Journal, 23(2): 206-213.

Mikesell, John L. 2010. "The Contribution of Local Sales and Income Taxes to Fiscal Autonomy." Working Paper.

Mintz, Jack, and Henry Tulkens. 1986. "Commodity Tax Competition Between Member States of a Federation: Equilibrium and Efficiency." Journal of Public Economics, 29(2): 132-172.

Nielsen, Søren Bo. 2001. "A Simple Model of Commodity Taxation and Cross-Border Shopping." The Scandinavian Journal of Economics, 103(4): 599-623.

Poterba, James M. 1996. "Retail Price Reactions to Changes in State and Local Sales Taxes." National Tax Journal, 49(2): 165-176.

Revelli, Federico. 2012. "Geografiscal federalism." Working paper in preparation for the Handbook of Fiscal Federalism. 
Rogers, Cynthia L. 2004. "Local Option Sales Tax (LOST) Policy on the Urban Fringe." The Journal of Regional Analysis and Policy, 34(1): 28-50.

Rohlin, Shawn, Stuart S. Rosenthal, and Amanda Ross. 2012. "Tax Avoidance and Business Location in a State Border Model." Working Paper.

Schragger, Richard C. 2001. "The Limits of Localism." Michigan Law Review, 100(2): 371-472.

Schragger, Richard C. 2006. "Can Strong Mayors Empower Weak Cities? On the Power of Local Executives in a Federal System." The Yale Law Journal, 115(9): 2542-2578.

Seegert, Nathan. 2012. "Optimal Taxation with Volatility a Theoretical and Empirical Decomposition." Working Paper.

Sjoquist, David D., and Rayna Stoycheva. 2012. "The Oxford Handbook of State and Local Government Finance." , ed. Robert D. Ebel and John E. Petersen, Chapter Local Revenue Diversification: User Charges, Sales Taxes, and Income Taxes, 429-462. Oxford University Press.

Sjoquist, David L., William Smith, Sally Wallace, and Mary Beth Walker. 2007. "An Analysis of the Time to Adoption of Local Sales Taxes: A Duration Model Approach." Public Budgeting and Finance, 27(1): 20-40.

Slemrod, Joel, and Christian Gillitzer. 2013. "Insights from a Tax-System Perspective." CESifo Economic Studies, 1-31.

Slemrod, Joel, and Christian Gillitzer. 2014. Tax Systems. MIT Press.

Thompson, Jeffrey P., and Shawn Rohlin. 2012. "The Effect of Sales Taxes on Employment: New Evidence from Cross-Border Panel Data Analysis." National Tax Journal, 65(4): 1023-1042.

Tosun, Mehmet S., and Mark L. Skidmore. 2007. "Cross-Border Shopping and the Sales Tax: An Examination of Food Purchases in West Virginia." B.E. Journal of Economic Analysis and Policy, 7(1): 1-18.

Trandel, Gregory. 1994. "Interstate Commodity Tax Differentials and the Distribution of Residents." Journal of Public Economics, 53(3): 435-457.

Walsh, Michael, and Jonathan Jones. 1988. "More Evidence on the Border Tax Effect: The Case of West Virginia, 1979-84." National Tax Journal, 41(2): 261-265. 
Wildasin, David. 2011. "Fiscal Competition for Imperfectly-Mobile Labor and Capital: A Comparative Dynamic Analysis." Journal of Public Economics, 95: 1312-1321.

Winters, John V. 2009. "Wages and Prices: Are Workers Fully Compensated for Cost of Living Differences?" Regional Science and Urban Economics, 39(5): 632-643.

Yu, Jihai, Robert de Jong, and Lung-Fei Lee. 2008. "Quasi-maximum Likelihood Estimators for Spatial Dynamic Panel Data with Fixed Effects when Both n and T Are Large." Journal of Econometrics, 146(1): 118-134.

Zhoa, Zhirong. 2005. "Motivations, Obstacles, and Resources: The Adoption of the General Purpose Local Option Sales Tax in Georgia Counties." Public Finance Review, 33(6): $721-746$. 
Figure 1: Tax Rates over Time
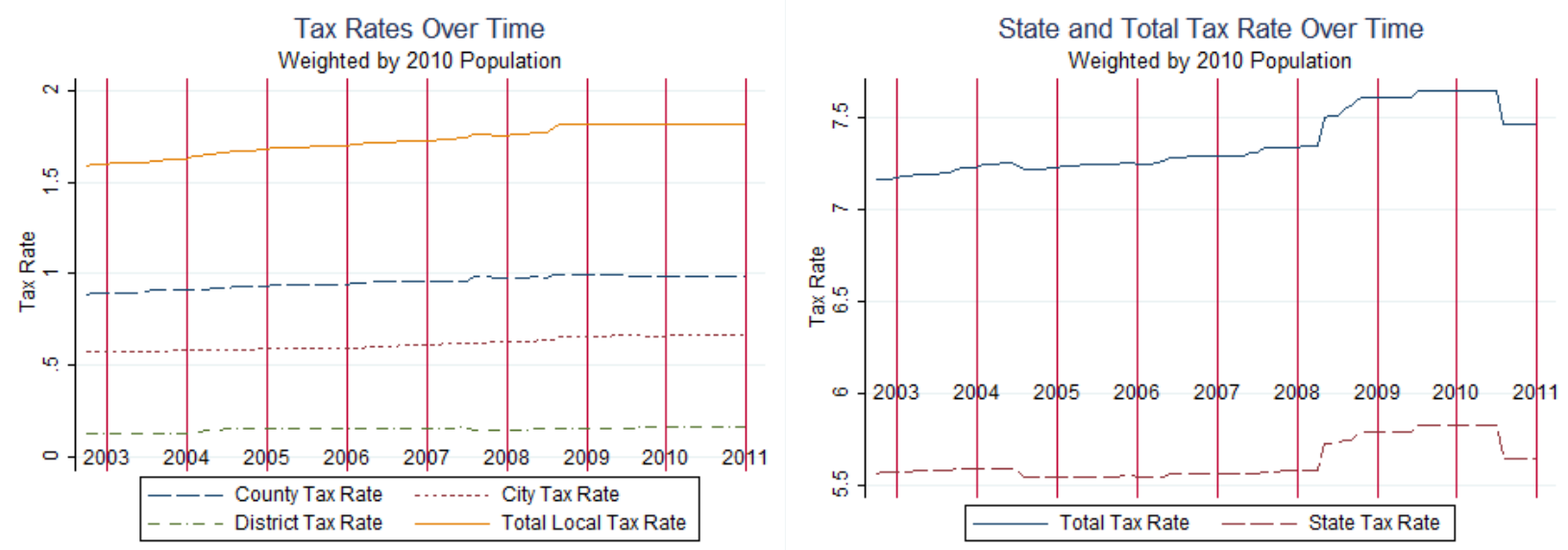

These figures show how the weighted average of tax rates have evolved over time using data at the monthly frequency. The averages - including the state tax rate data - include only states that allow for local sales tax rates at one or more levels of government. Thus, the county, town and district data averages will include some states that do not allow for each of these respective taxes. The left figure looks at the time series properties of only local rates, while the right figure looks at the state rates and the total (state + local rates).

Figure 2: Percentage Change in Tax Rates over Time

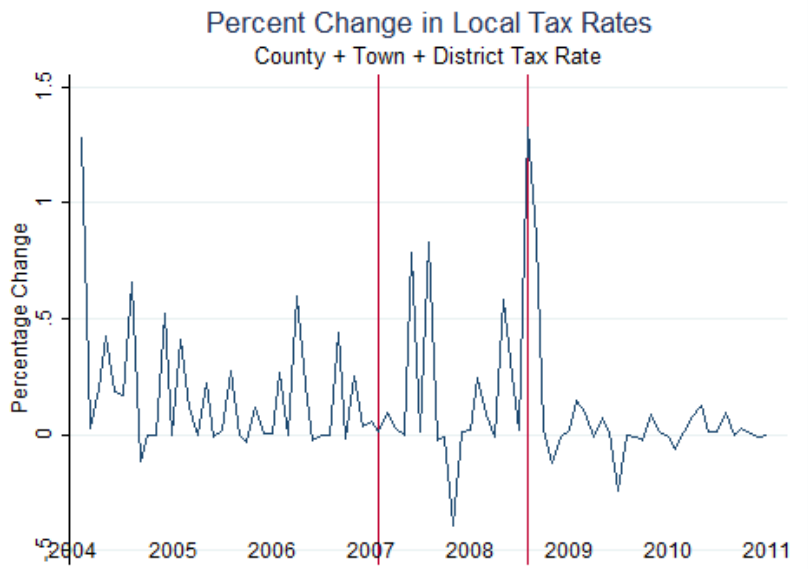

These figures show how the percentage change of local tax rates have evolved over time using data at the monthly frequency. The series starts at the end of 2004 in order to eliminate the highly volatile year prior. The red lines mark the start and end of the Great Recession (December 2007 to June 2009). The years on the horizontal axis denote December of the year. 
Figure 3: Standard Deviations over Time
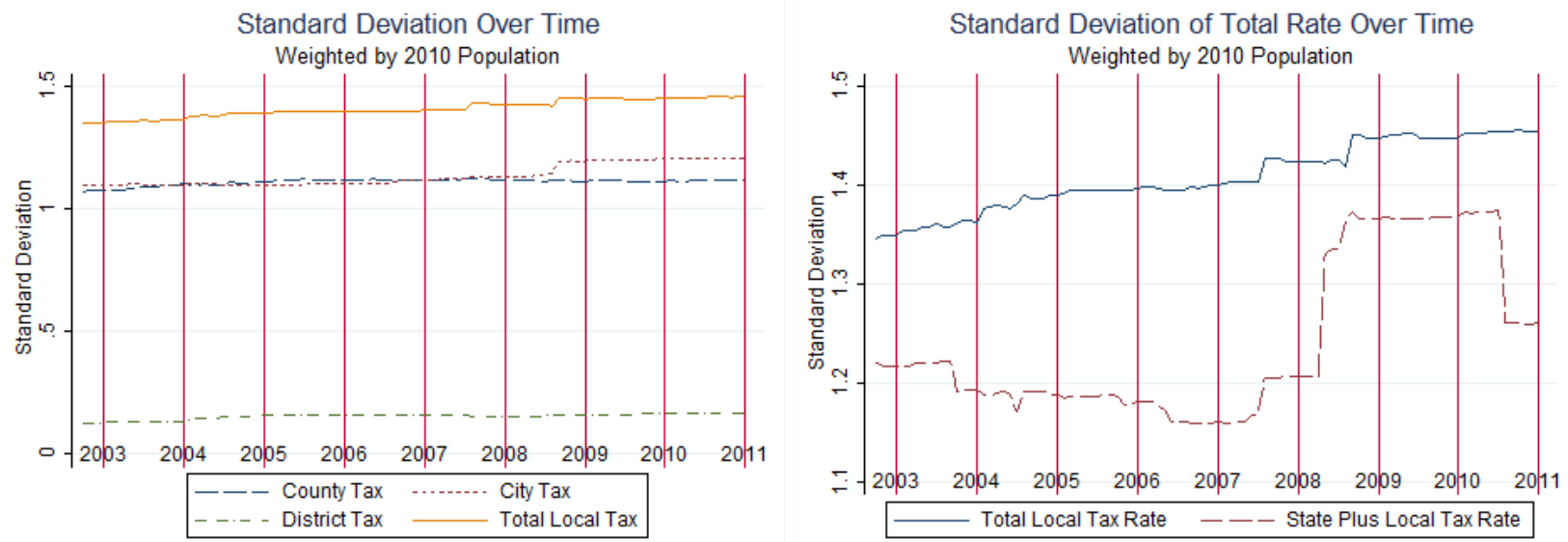

These figures show how the weighted average of the standard deviation of tax rates have evolved over time using data at the monthly frequency. The averages - including the state tax rate data - include only states that allow for local sales tax rates at one or more levels of government. Thus, the county, town and district data averages will include some states that do not allow for each of these respective taxes. The left figure looks at the time series properties of only local rates, while the right figure looks at the state rates and the total (state + local rates).

Figure 4: Relationship of Local Tax Rates and State Tax Rates Over Time

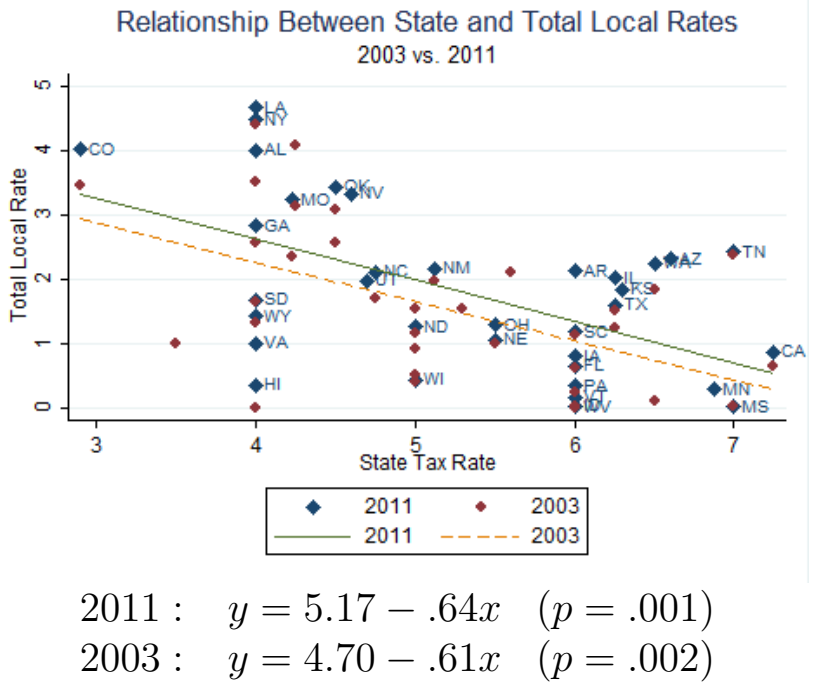

The figure plots the weighted total local tax rate (town plus county plus district) and the state tax rate for 2003 and 2011. States with a zero state tax rate or no local tax rates are excluded. The line of best fit is from a univariate regression of the same variables. 
Figure 5: Relationship of Standard Deviation and State / Local Tax Rates
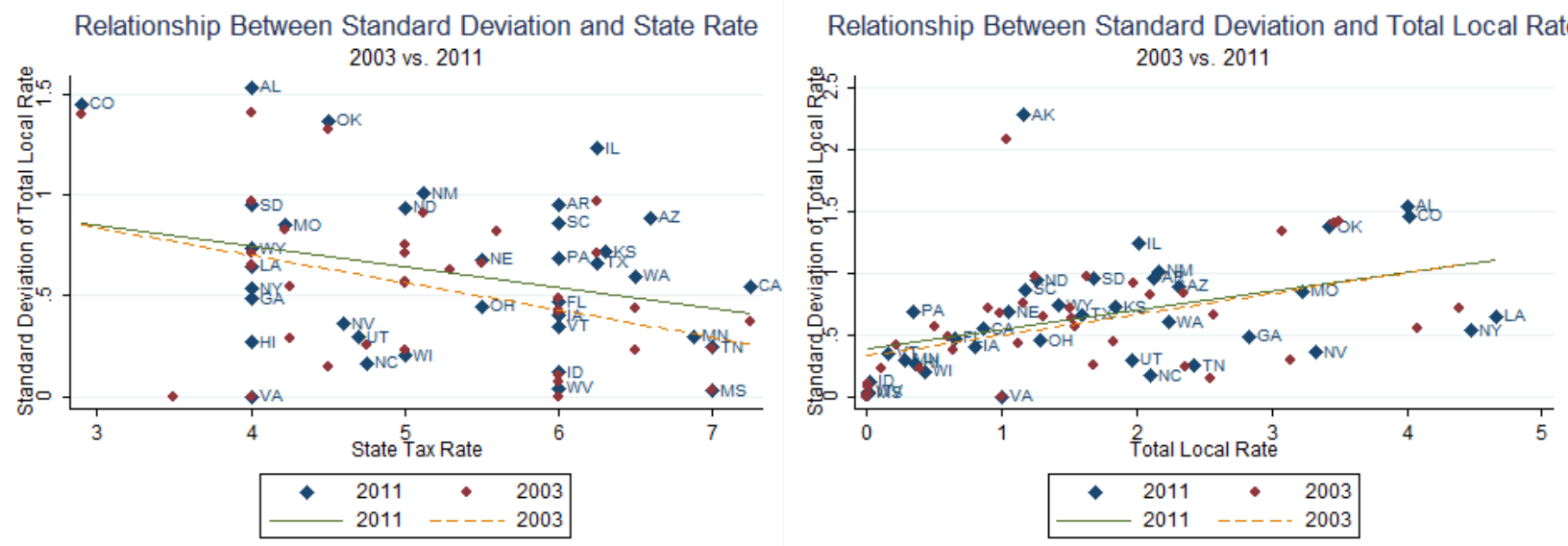

2011: $y=1.16-.10 x \quad(p=.112)$

$2011: \quad y=.39+.15 x \quad(p=.009)$

$2003: y=1.24-.14 x \quad(p=.037)$

$2003: y=.33+.17 x \quad(p=.005)$

The left figure plots the weighted standard deviation of the total local tax rate (town plus county plus district) and the state tax rate for 2003 and 2011. States with a zero state tax rate or no local tax rates are excluded. The right figure plots the same standard deviation with respect to the weighted average of the local tax rates. The line of best fit is from a univariate regression of the same variables.

Figure 6: Patterns of Changes in Total Local Rates from 2003 to 2011
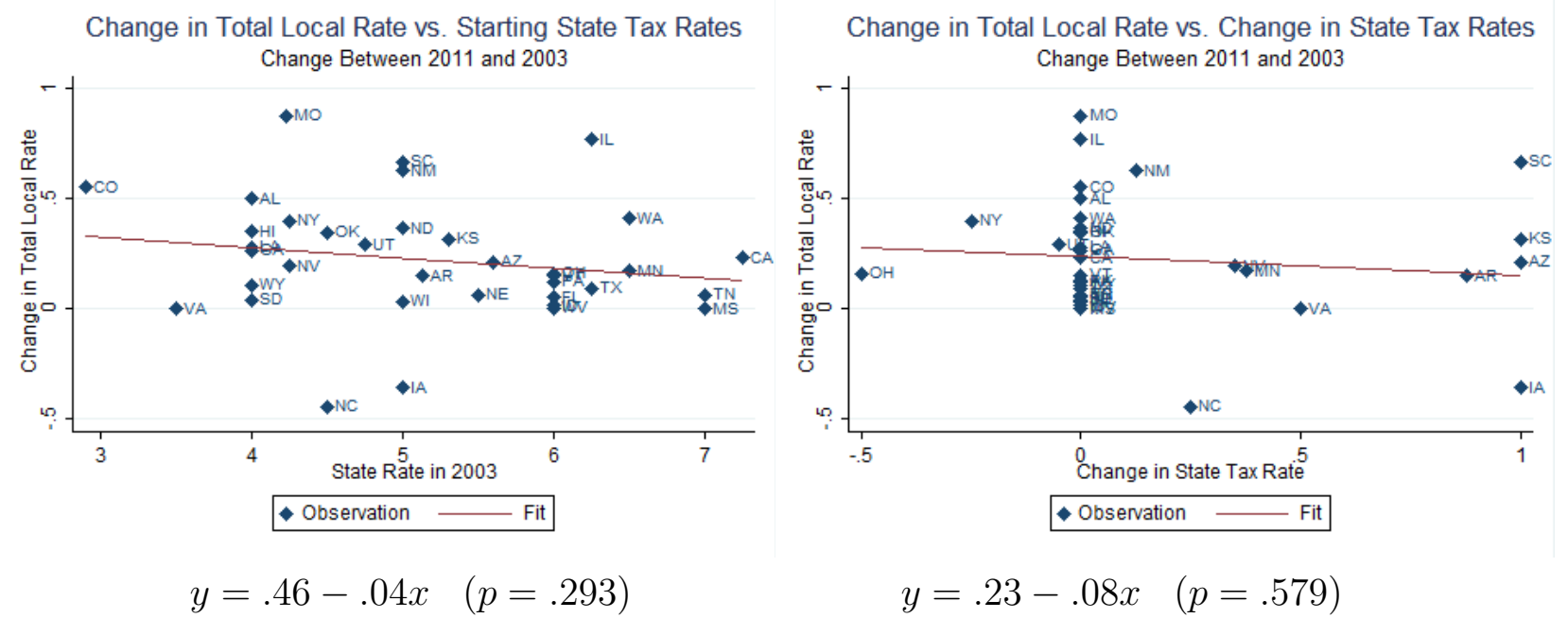

The left figure plots the change in the weighted average of the total local tax rate (town plus county plus district) from 2003 to 2011 and the state tax rate. States with a zero state tax rate or no local tax rates are excluded. The right figure plots the same change with respect to the change in the state tax rate. The line of best fit is from a univariate regression of the same variables. 
Figure 7: Patterns of Changes in Standard Deviations of Total Local Rates from 2003 to 2011
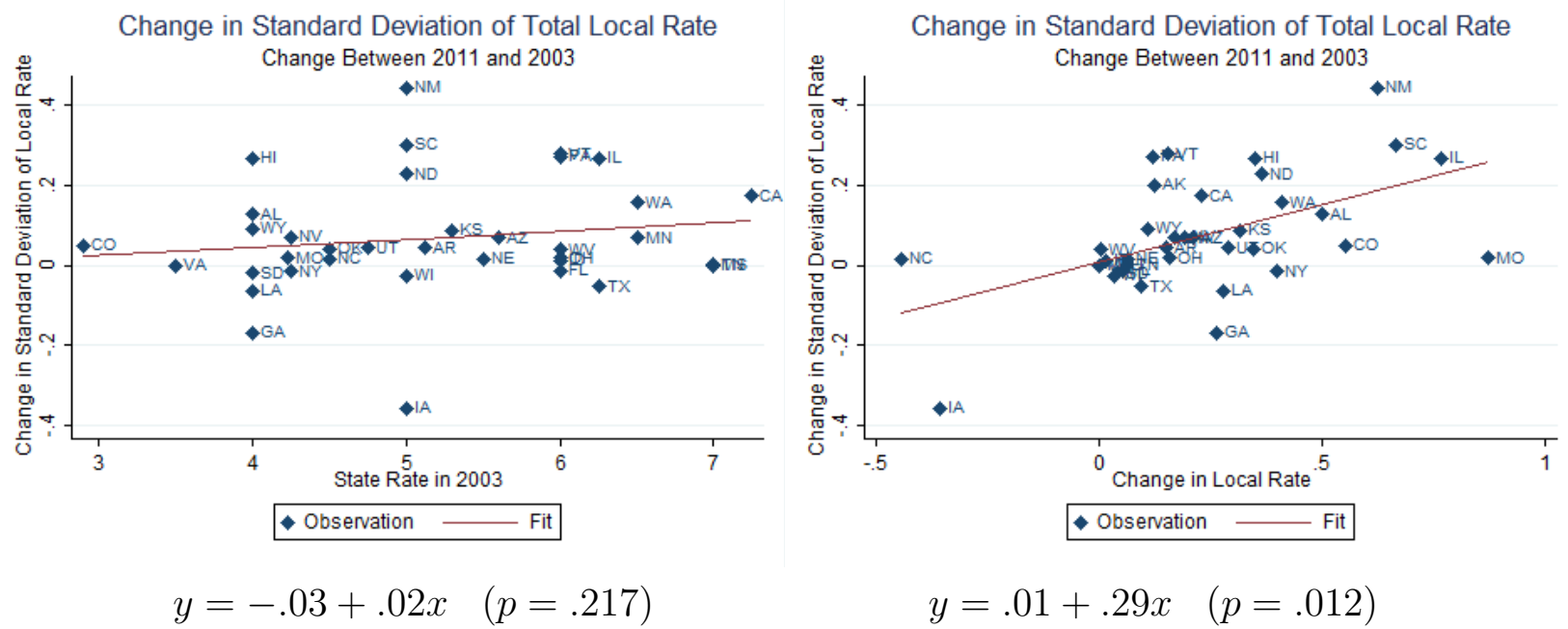

The left figure plots the change in the weighted standard deviation of the total local tax rate (town plus county plus district) from 2003 to 2011 and the state tax rate. States with a zero state tax rate or no local tax rates are excluded. The right figure plots the same change with respect to the change in the local tax rate. The line of best fit is from a univariate regression of the same variables.

Figure 8: Patterns of Changes in Levels of Total Local Rates from 2003 to 2011
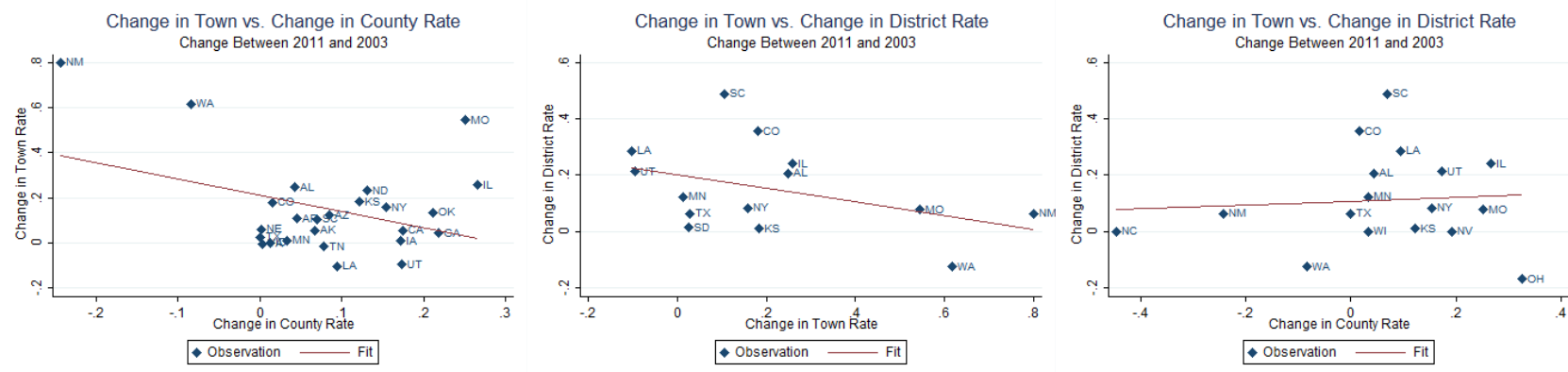

$$
y=.21-.72 x \quad(p=.263) \quad y=.20-.24 x \quad(p=.052) \quad y=.11+.07 x \quad(p=.712)
$$

The left figure plots the change in the weighted average of the town tax rate from 2003 to 2011 and the change in the weighted average of the county tax rates within the same period. The middle figure plots the change in the weighted average of the district tax rate from 2003 to 2011 and the change in the weighted average of the town tax rates within the same period. The right figure plots the change in the weighted average of the district tax rate from 2003 to 2011 and the change in the weighted average of the county tax rates within the same period. States that do not allow for both types of taxes are omitted. The line of best fit is from a univariate regression of the same variables. 
Figure 9: Changes in State Tax Rates over Time
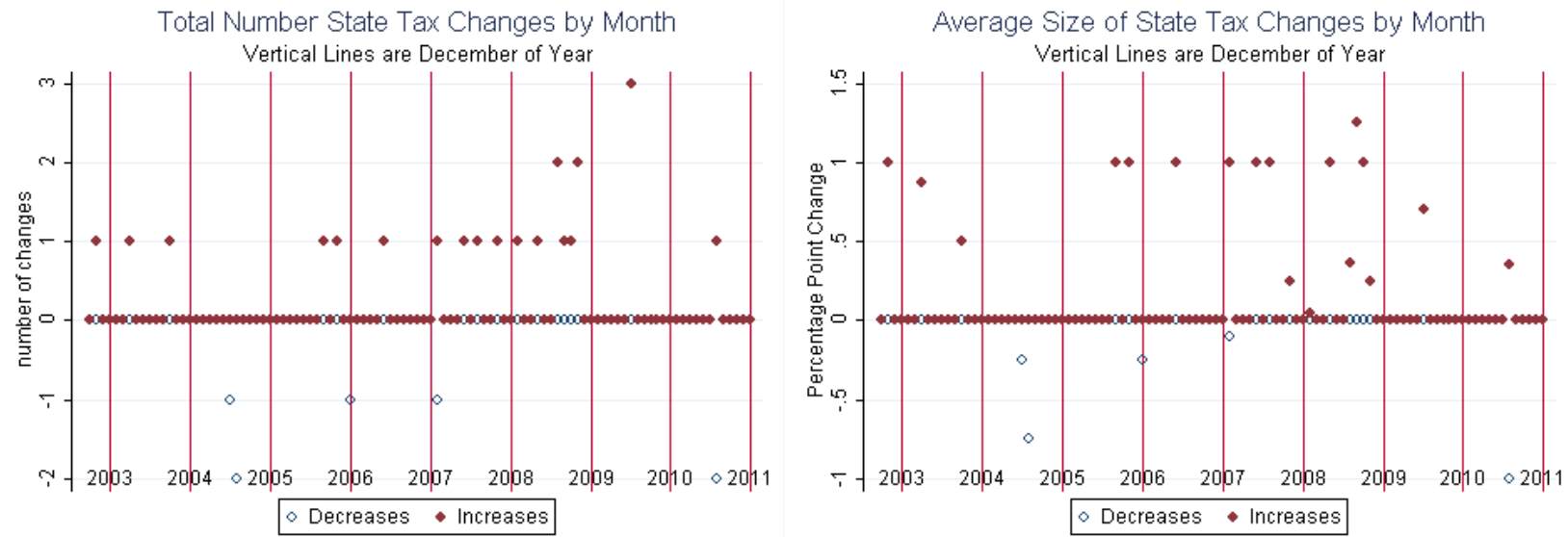

The left figure plots the total number of state tax changes observed in each month. The right panel plots the average unweighted state sales tax rate change. Increases are presented on the positive vertical scale and decreases in the tax rate are plotted on the negative vertical scale.

Figure 10: Changes in County Tax Rates over Time - Number of Changes and Size of Change
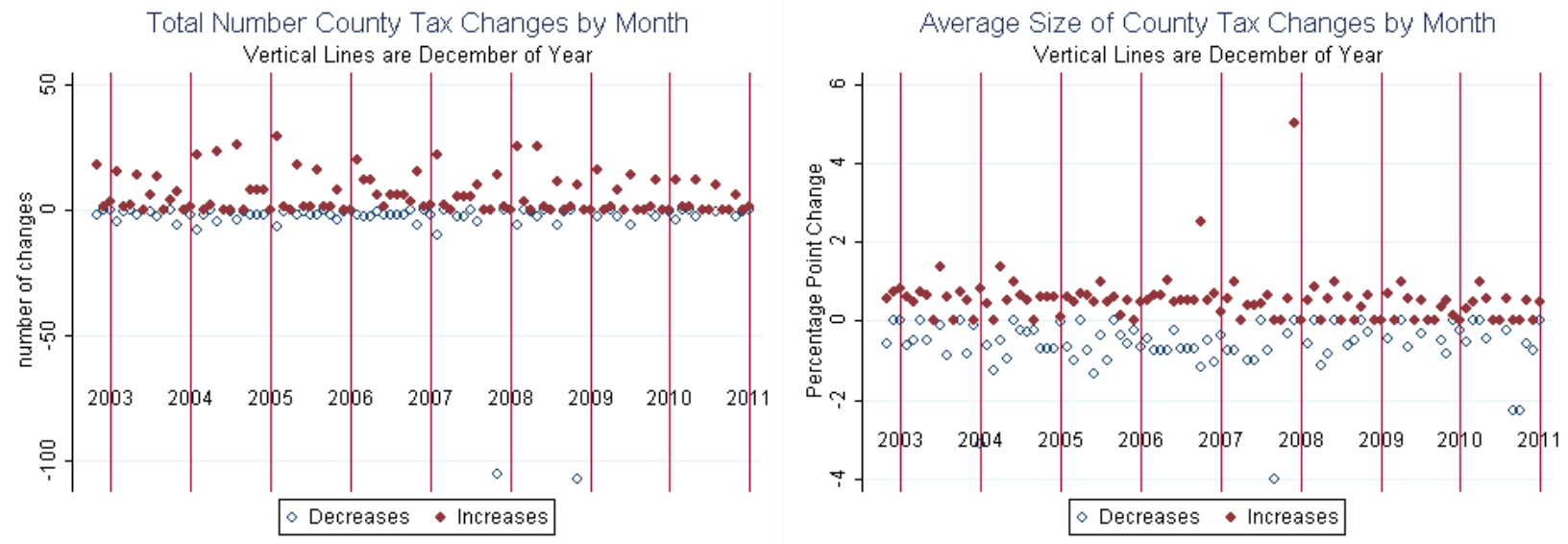

The left figure plots the total number of county tax changes observed in each month. The right panel plots the average unweighted county sales tax rate change. Increases are presented on the positive vertical scale and decreases in the tax rate are plotted on the negative vertical scale. Only county tax changes that affect the entire county are included. 
Figure 11: Changes in County Tax Rates over Time - Number of Towns and People Exposed
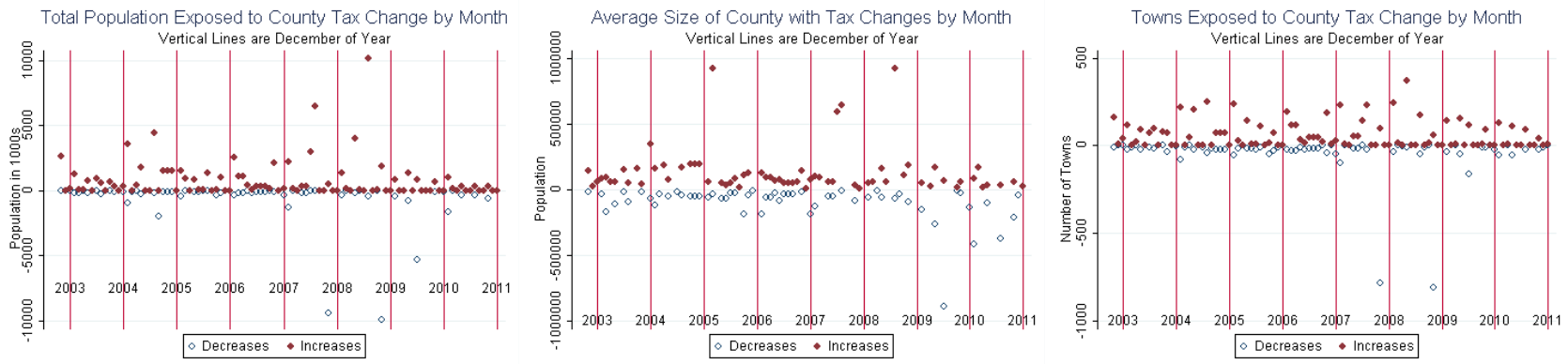

The left figure plots the total number of people affected by a county tax changes in each month (in 1000s of people). A few months with extremely large values are omitted. The middle panel shows the average size of counties changing a tax rate in each month. Again, a few months with extremely large values are omitted. The right panel plots the number of towns that are exposed to county tax rate changes by month.

Increases are presented on the positive vertical scale and decreases in the tax rate are plotted on the negative vertical scale. Only county tax changes that affect the entire county are included.

Figure 12: Changes in Town Tax Rates over Time - Number of Changes and Size of Change
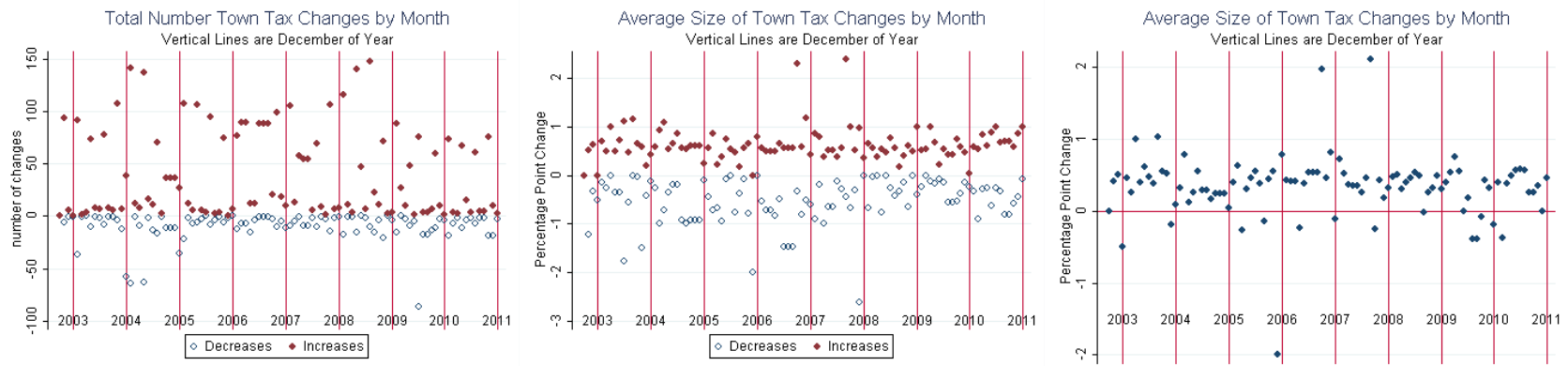

The left figure plots the total number of town tax changes observed in each month. The middle panel plots the average unweighted county sales tax rate change. Increases are presented on the positive vertical scale and decreases in the tax rate are plotted on the negative vertical scale. The right panel shows the average tax change where increases and decreases are not calculated separately. 
Figure 13: Changes in Town Tax Rates over Time - Number of People Exposed
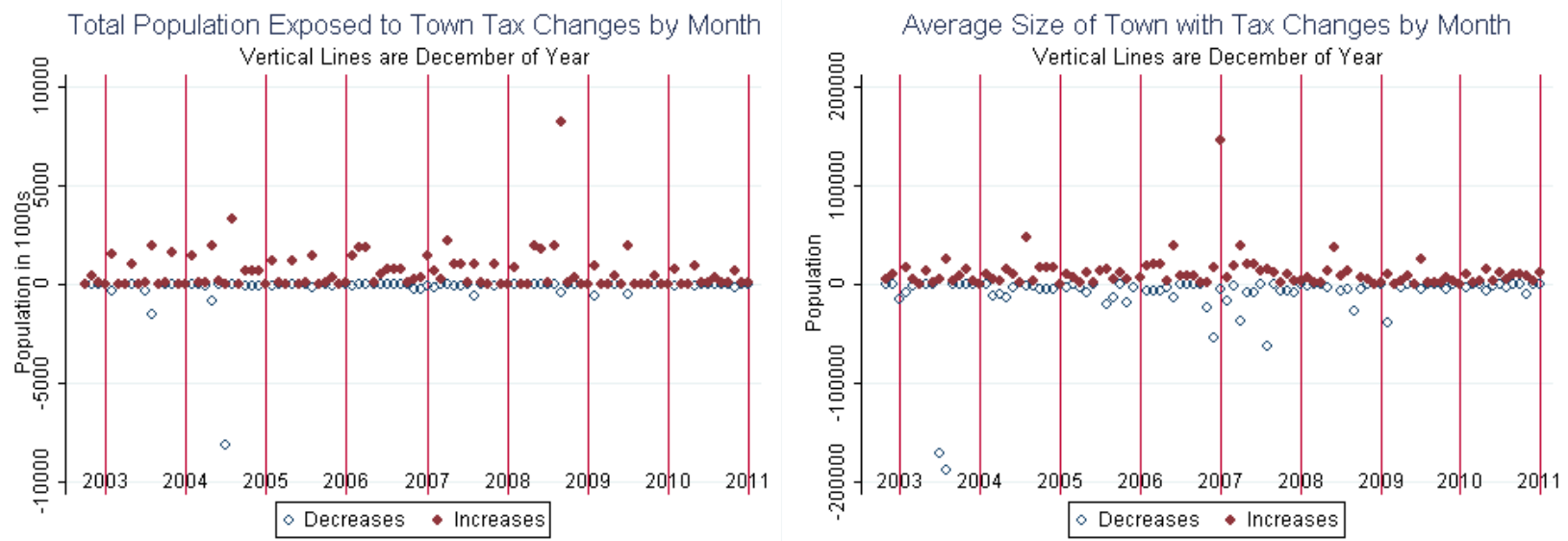

The left figure plots the total number of people affected by a town tax changes in each month (in 1000s of people). A few months with extremely large values are omitted. The right panel shows the average size of towns changing a tax rate in each month. Again, a few months with extremely large values are omitted.

Increases are presented on the positive vertical scale and decreases in the tax rate are plotted on the negative vertical scale.

Figure 14: Changes in Tax Rates over Time - Relationship to Initial Value
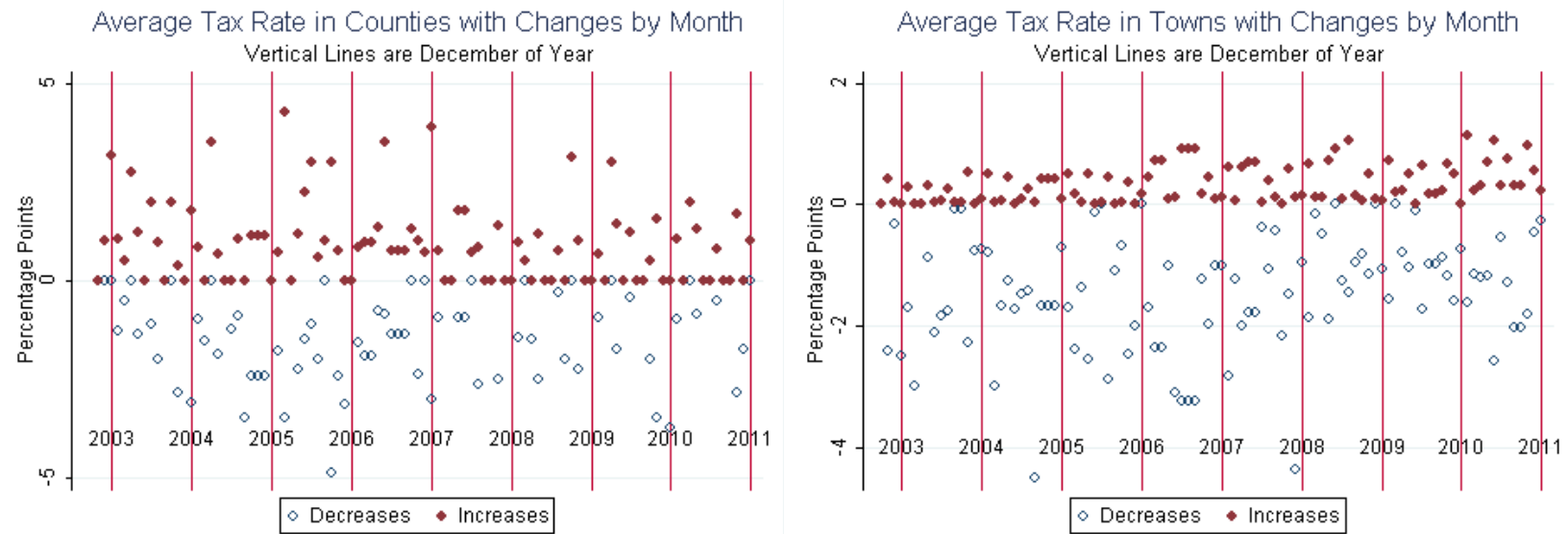

The left figure plots the average county tax rate in the period prior to a county changing its tax rate. The right panel plots the average town tax rate in the period prior to a town changing its tax rate. Increases are presented on the positive vertical scale and decreases in the tax rate are plotted on the negative vertical scale. 


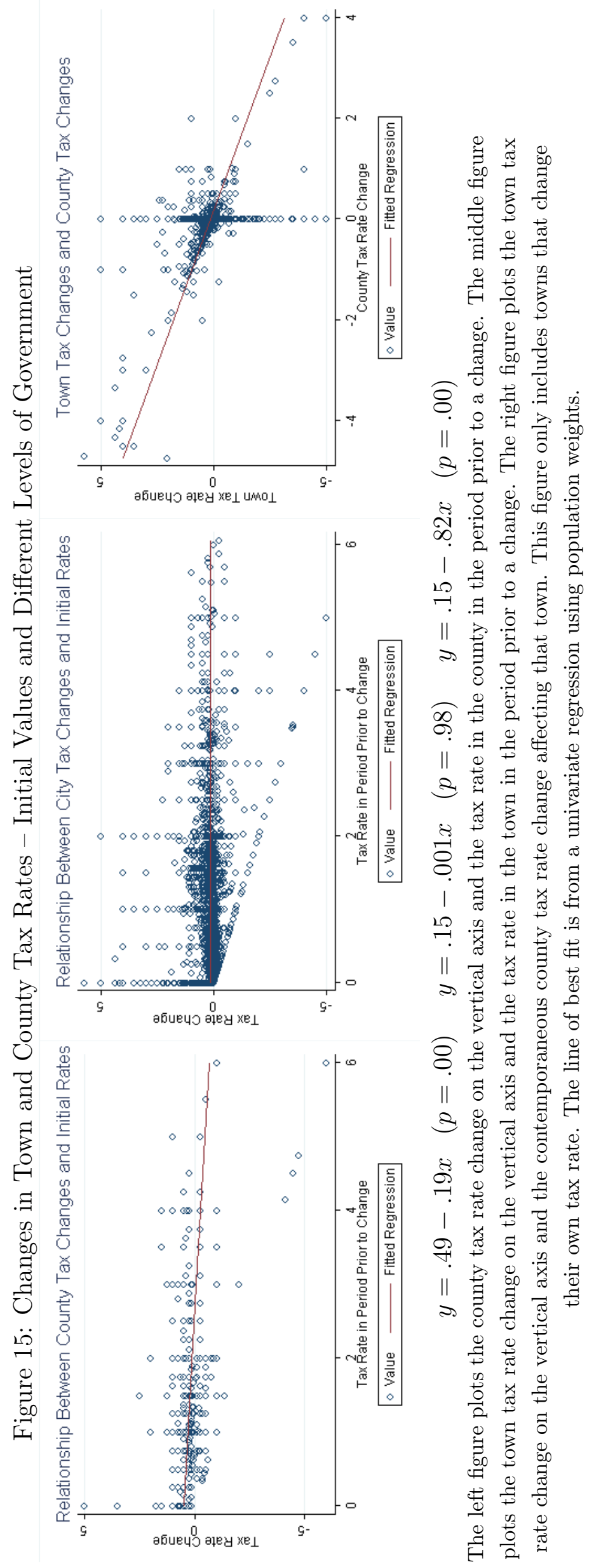


Figure 16: State Tax Changes, 2003 to 2011

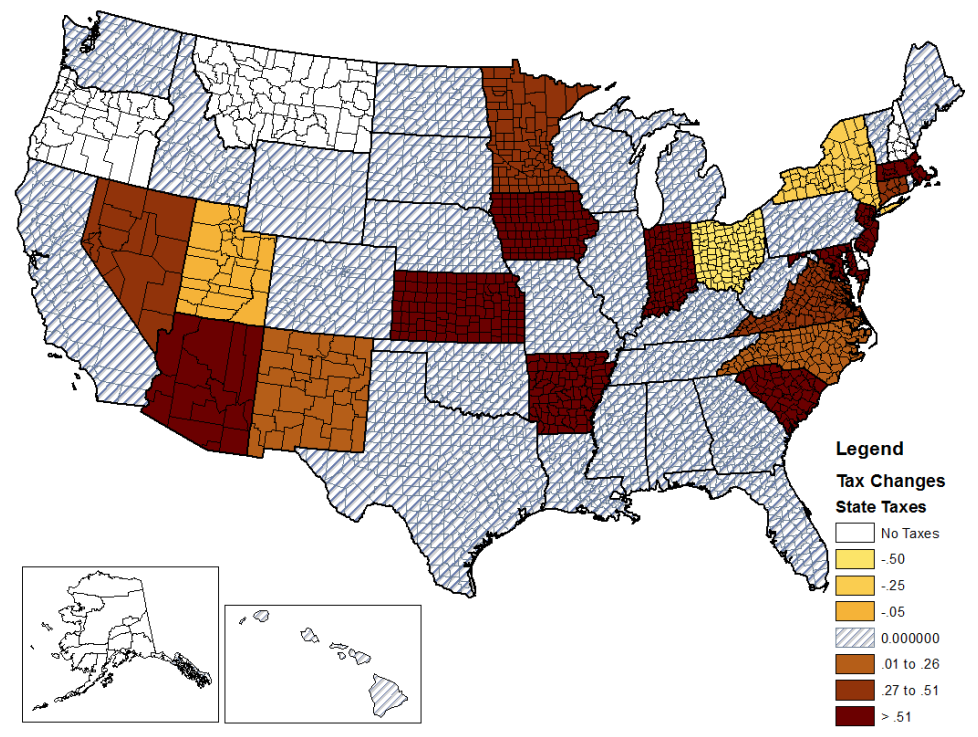

This figure shows changes in state tax rates from 2003 to 2011. Hashed counties are counties where tax rates are the same in 2011 as they were in 2003. Hallow counties are counties in states with no state sales tax rates. Darker colors imply larger tax increases and lighter colors imply larger tax decreases.

Figure 17: Total (State Plus Local) Tax Changes, 2003 to 2011

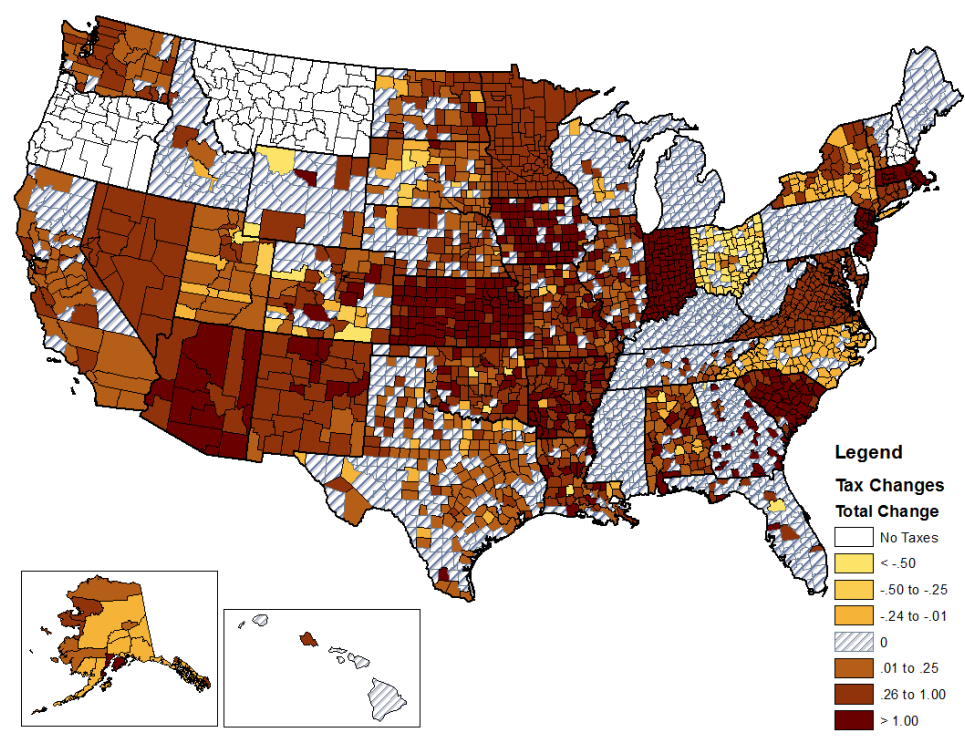

This figure shows changes in total (state plus each county's population weighted county, town, and district) tax rates from 2003 to 2011. Hashed counties are counties where total tax rates are the same in 2011 as they were in 2003. Hallow counties are counties in states with no sales tax rates (at any level of government). Darker colors imply larger tax increases and lighter colors imply larger tax decreases. 
Table 1: Tax Rates and SDs for December 2011

\begin{tabular}{|c|c|c|c|c|c|c|c|c|c|c|}
\hline State & State Rate & Total Local & County & Town & District & Total & sd(Total Local) & sd(County) & sd(Town) & sd(District) \\
\hline Alabama & 4 & 3.999 & 1.603 & 2.189 & 0.206 & 7.999 & 1.538 & 0.992 & 1.686 & 0.418 \\
\hline Alaska & 0 & 1.155 & 0.56 & 0.595 & 0 & 1.155 & 2.274 & 1.549 & 1.685 & 0 \\
\hline Arizona & 6.6 & 2.307 & 0.698 & 1.609 & 0 & 8.907 & 0.89 & 0.198 & 0.864 & 0 \\
\hline Arkansas & 6 & 2.123 & 1.216 & 0.907 & 0 & 8.123 & 0.956 & 0.542 & 0.847 & 0 \\
\hline California & 7.25 & 0.864 & 0.806 & 0.059 & 0 & 8.114 & 0.546 & 0.539 & 0.183 & 0 \\
\hline Colorado & 2.9 & 4.012 & 0.719 & 2.502 & 0.792 & 6.912 & 1.456 & 0.616 & 1.458 & 0.553 \\
\hline Connecticut & 6.35 & 0 & 0 & 0 & 0 & 6.35 & 0 & 0 & 0 & 0 \\
\hline Delaware & 0 & 0 & 0 & 0 & 0 & 0 & 0 & 0 & 0 & 0 \\
\hline District of Columbia & 6 & 0 & 0 & 0 & 0 & 6 & 0 & 0 & 0 & 0 \\
\hline Florida & 6 & 0.647 & 0.647 & 0 & 0 & 6.647 & 0.47 & 0.47 & 0 & 0 \\
\hline Georgia & 4 & 2.827 & 2.784 & 0.043 & 0 & 6.827 & 0.483 & 0.415 & 0.205 & 0 \\
\hline Hawaii & 4 & 0.35 & 0.35 & 0 & 0 & 4.35 & 0.267 & 0.267 & 0 & 0 \\
\hline Idaho & 6 & 0.019 & 0.013 & 0.006 & 0 & 6.019 & 0.12 & 0.08 & 0.09 & 0 \\
\hline Illinois & 6.25 & 2.007 & 0.649 & 0.732 & 0.625 & 8.257 & 1.235 & 0.59 & 0.576 & 0.451 \\
\hline Indiana & 7 & 0 & 0 & 0 & 0 & 7 & 0 & 0 & 0 & 0 \\
\hline Iowa & 6 & 0.796 & 0.788 & 0.008 & 0 & 6.796 & 0.4 & 0.405 & 0.086 & 0 \\
\hline Kansas & 6.3 & 1.836 & 1.036 & 0.789 & 0.011 & 8.136 & 0.72 & 0.36 & 0.676 & 0.046 \\
\hline Kentucky & 6 & 0 & 0 & 0 & 0 & 6 & 0 & 0 & 0 & 0 \\
\hline Louisiana & 4 & 4.666 & 2.243 & 1.747 & 0.676 & 8.666 & 0.647 & 2.131 & 2.305 & 1.361 \\
\hline Maine & 5 & 0 & 0 & 0 & 0 & 5 & 0 & 0 & 0 & 0 \\
\hline Maryland & 6 & 0 & 0 & 0 & 0 & 6 & 0 & 0 & 0 & 0 \\
\hline Massachusetts & 6.25 & 0 & 0 & 0 & 0 & 6.25 & 0 & 0 & 0 & 0 \\
\hline Michigan & 6 & 0 & 0 & 0 & 0 & 6 & 0 & 0 & 0 & 0 \\
\hline Minnesota & 6.875 & 0.276 & 0.034 & 0.118 & 0.124 & 7.151 & 0.296 & 0.069 & 0.232 & 0.126 \\
\hline Mississippi & 7 & 0.003 & 0 & 0.003 & 0 & 7.003 & 0.027 & 0 & 0.027 & 0 \\
\hline Missouri & 4.225 & 3.223 & 1.306 & 1.528 & 0.389 & 7.448 & 0.85 & 0.48 & 1.076 & 0.537 \\
\hline Montana & 0 & 0 & 0 & 0 & 0 & 0 & 0 & 0 & 0 & 0 \\
\hline Nebraska & 5.5 & 1.049 & 0.002 & 1.047 & 0 & 6.549 & 0.682 & 0.033 & 0.684 & 0 \\
\hline Nevada & 4.6 & 3.328 & 3.289 & 0 & 0.039 & 7.928 & 0.358 & 0.396 & 0 & 0.1 \\
\hline New Hampshire & 0 & 0 & 0 & 0 & 0 & 0 & 0 & 0 & 0 & 0 \\
\hline New Jersey & 7 & 0 & 0 & 0 & 0 & 7 & 0 & 0 & 0 & 0 \\
\hline New Mexico & 5.125 & 2.163 & 0.26 & 1.838 & 0.064 & 7.288 & 1.011 & 0.469 & 1.245 & 0.19 \\
\hline New York & 4 & 4.477 & 2.228 & 1.996 & 0.252 & 8.477 & 0.533 & 2.213 & 2.435 & 0.194 \\
\hline North Carolina & 4.75 & 2.103 & 2.055 & 0 & 0.048 & 6.853 & 0.166 & 0.104 & 0 & 0.149 \\
\hline North Dakota & 5 & 1.257 & 0.135 & 1.122 & 0 & 6.257 & 0.937 & 0.229 & 0.853 & 0 \\
\hline Ohio & 5.5 & 1.279 & 1.263 & 0 & 0.015 & 6.779 & 0.448 & 0.458 & 0 & 0.119 \\
\hline Oklahoma & 4.5 & 3.427 & 0.721 & 2.706 & 0 & 7.927 & 1.373 & 0.569 & 1.552 & 0 \\
\hline Oregon & 0 & 0 & 0 & 0 & 0 & 0 & 0 & 0 & 0 & 0 \\
\hline Pennsylvania & 6 & 0.337 & 0.337 & 0 & 0 & 6.337 & 0.689 & 0.689 & 0 & 0 \\
\hline Rhode Island & 7 & 0 & 0 & 0 & 0 & 7 & 0 & 0 & 0 & 0 \\
\hline South Carolina & 6 & 1.172 & 0.261 & 0.269 & 0.642 & 7.172 & 0.863 & 0.441 & 0.512 & 0.636 \\
\hline South Dakota & 4 & 1.673 & 0 & 1.521 & 0.152 & 5.673 & 0.95 & 0 & 0.849 & 0.732 \\
\hline Tennessee & 7 & 2.421 & 2.39 & 0.031 & 0 & 9.421 & 0.244 & 0.323 & 0.248 & 0 \\
\hline Texas & 6.25 & 1.596 & 0.13 & 1.037 & 0.429 & 7.846 & 0.663 & 0.222 & 0.679 & 0.443 \\
\hline Utah & 4.7 & 1.968 & 1.071 & 0.324 & 0.573 & 6.668 & 0.293 & 0.476 & 0.472 & 0.289 \\
\hline Vermont & 6 & 0.16 & 0 & 0.16 & 0 & 6.16 & 0.347 & 0 & 0.347 & 0 \\
\hline Virginia & 4 & 1 & 0.693 & 0.307 & 0 & 5 & 0 & 0.466 & 0.466 & 0 \\
\hline Washington & 6.5 & 2.233 & 0.277 & 1.728 & 0.228 & 8.733 & 0.597 & 0.559 & 1.098 & 0.549 \\
\hline West Virginia & 6 & 0.002 & 0 & 0.002 & 0 & 6.002 & 0.04 & 0 & 0.04 & 0 \\
\hline Wisconsin & 5 & 0.425 & 0.373 & 0 & 0.053 & 5.425 & 0.202 & 0.22 & 0 & 0.107 \\
\hline Wyoming & 4 & 1.418 & 1.418 & 0 & 0 & 5.418 & 0.734 & 0.734 & 0 & 0 \\
\hline US & 5.629 & 1.482 & 0.803 & 0.542 & 0.136 & 7.11 & 1.491 & 1.075 & 1.117 & 0.36 \\
\hline
\end{tabular}

The first six numerical columns present the weighted average of the state, total local (county + town + district), county, town, district, and total combined tax rates. The final four columns present the weighted standard deviations of these rates within a state. All population weights are from the 2010 ACS. The total tax rate is the sum of the first two columns. 
Table 2: Tax Rates and SDs for December 2003

State State Rate Total Local County Town District Total sd(Total Local)

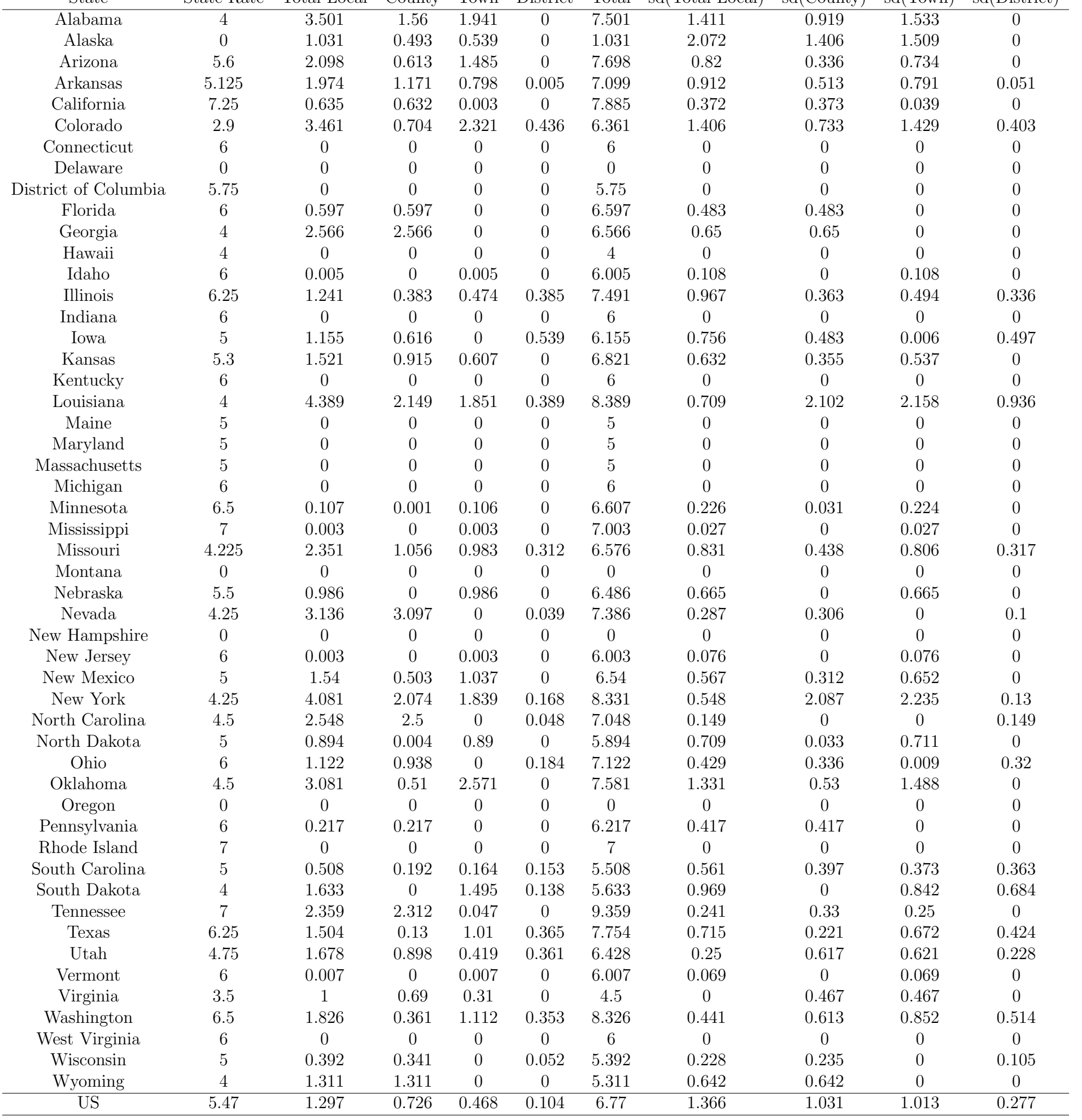

The first six numerical columns present the weighted average of the state, total local (county + town + district), county, town, district, and total combined tax rates. The final four

columns present the weighted standard deviations of these rates within a state. All population weights are from the 2010 ACS. The total tax rate is the sum of the first two columns. 
Table 3: Changes in Tax Rates

\begin{tabular}{|c|c|c|c|c|c|c|c|c|c|c|c|c|c|c|}
\hline & \multicolumn{4}{|c|}{ State Changes } & \multicolumn{5}{|c|}{ County Changes } & \multicolumn{5}{|c|}{ Town Changes } \\
\hline State & (1) & $(2)$ & (3) & (4) & $(0)$ & (1) & $(2)$ & $(3)$ & (4) & $(0)$ & $(1)$ & $(2)$ & $(3)$ & $(4)$ \\
\hline Alabama & 0 & 0 & 0 & 0 & 67 & 13 & 5 & 18 & 0.417 & 476 & 234 & 61 & 295 & 0.578 \\
\hline Alaska & 0 & 0 & 0 & 0 & 24 & 11 & 8 & 19 & 0.184 & 288 & 41 & 21 & 62 & 0.245 \\
\hline Arizona & 1 & 0 & 1 & 1 & 15 & 6 & 2 & 8 & 0.161 & 205 & 64 & 17 & 81 & 0.346 \\
\hline Arkansas & 1 & 0 & 1 & 0.875 & 75 & 35 & 17 & 52 & 0.252 & 498 & 131 & 60 & 191 & 0.377 \\
\hline California & 1 & 1 & 2 & 0 & 58 & 6 & 0 & 6 & 0.417 & 1152 & 107 & 21 & 128 & 0.357 \\
\hline Colorado & 0 & 0 & 0 & 0 & 63 & 12 & 5 & 17 & 0.076 & 333 & 98 & 37 & 135 & 0.429 \\
\hline Connecticut & 1 & 0 & 1 & 0.35 & 8 & 0 & 0 & 0 & 0 & 104 & 0 & 0 & 0 & 0 \\
\hline Delaware & 0 & 0 & 0 & 0 & 3 & 0 & 0 & 0 & 0 & 58 & 0 & 0 & 0 & 0 \\
\hline $\begin{array}{l}\text { District of } \\
\text { Columbia }\end{array}$ & 1 & 0 & 1 & 0.25 & 1 & 0 & 0 & 0 & 0 & 1 & 0 & 0 & 0 & 0 \\
\hline Florida & 0 & 0 & 0 & 0 & 67 & 16 & 9 & 25 & 0.170 & 574 & 0 & 0 & 0 & 0 \\
\hline Georgia & 0 & 0 & 0 & 0 & 156 & 64 & 34 & 98 & 0.306 & 543 & 2 & 0 & 2 & 1 \\
\hline Hawaii & 0 & 0 & 0 & 0 & 4 & 1 & 0 & 1 & 0.500 & 66 & 0 & 0 & 0 & 0 \\
\hline Idaho & 1 & 1 & 2 & 0 & 44 & 2 & 1 & 3 & 0.167 & 195 & 3 & 2 & 5 & 0.400 \\
\hline Illinois & 0 & 0 & 0 & 0 & 102 & 33 & 3 & 36 & 0.553 & 1331 & 306 & 22 & 328 & 0.470 \\
\hline Indiana & 1 & 0 & 1 & 1 & 92 & 0 & 0 & 0 & 0 & 614 & 0 & 0 & 0 & 0 \\
\hline Iowa & 1 & 0 & 1 & 1 & 99 & 5 & 1 & 6 & 0.667 & 993 & 20 & 2 & 22 & 0.739 \\
\hline Kansas & 1 & 0 & 1 & 1 & 105 & 42 & 10 & 52 & 0.417 & 656 & 205 & 27 & 232 & 0.441 \\
\hline Kentucky & 0 & 0 & 0 & 0 & 119 & 0 & 0 & 0 & 0 & 421 & 0 & 0 & 0 & 0 \\
\hline Louisiana & 0 & 0 & 0 & 0 & 64 & 17 & 2 & 19 & 0.518 & 422 & 235 & 48 & 283 & 0.728 \\
\hline Maine & 0 & 0 & 0 & 0 & 16 & 0 & 0 & 0 & 0 & 122 & 0 & 0 & 0 & 0 \\
\hline Maryland & 1 & 0 & 1 & 1 & 24 & 0 & 0 & 0 & 0 & 334 & 0 & 0 & 0 & 0 \\
\hline Massachusetts & 1 & 0 & 1 & 1.25 & 14 & 0 & 0 & 0 & 0 & 194 & 0 & 0 & 0 & 0 \\
\hline Michigan & 0 & 0 & 0 & 0 & 83 & 0 & 0 & 0 & 0 & 619 & 0 & 0 & 0 & 0 \\
\hline Minnesota & 1 & 0 & 1 & 0.375 & 87 & 2 & 1 & 3 & 0.050 & 842 & 17 & 7 & 24 & 0.221 \\
\hline Mississippi & 0 & 0 & 0 & 0 & 82 & 0 & 0 & 0 & 0 & 319 & 0 & 0 & 0 & 0 \\
\hline Missouri & 0 & 0 & 0 & 0 & 115 & 84 & 15 & 99 & 0.270 & 973 & 696 & 130 & 826 & 0.319 \\
\hline Montana & 0 & 0 & 0 & 0 & 55 & 0 & 0 & 0 & 0 & 276 & 0 & 0 & 0 & 0 \\
\hline Nebraska & 0 & 0 & 0 & 0 & 93 & 0 & 0 & 0 & 0 & 548 & 118 & 15 & 133 & 0.690 \\
\hline Nevada & 1 & 0 & 1 & 0.35 & 17 & 11 & 3 & 14 & 0.134 & 100 & 0 & 0 & 0 & 0 \\
\hline $\begin{array}{c}\text { New } \\
\text { Hampshire }\end{array}$ & 0 & 0 & 0 & 0 & 10 & 0 & 0 & 0 & 0 & 87 & 0 & 0 & 0 & 0 \\
\hline New Jersey & 1 & 0 & 1 & 1 & 21 & 0 & 0 & 0 & 0 & 441 & 0 & 3 & 3 & -2.000 \\
\hline New Mexico & 1 & 0 & 1 & 0.125 & 33 & 18 & 2 & 20 & 0.106 & 249 & 266 & 98 & 364 & 0.306 \\
\hline New York & 0 & 1 & 1 & -0.25 & 58 & 25 & 5 & 30 & 0.521 & 1043 & 8 & 6 & 14 & -0.295 \\
\hline $\begin{array}{c}\text { North } \\
\text { Carolina }\end{array}$ & 3 & 2 & 5 & 0.05 & 100 & 17 & 199 & 216 & -0.211 & 627 & 0 & 0 & 0 & 0 \\
\hline North Dakota & 0 & 0 & 0 & 0 & 53 & 3 & 0 & 3 & 0.667 & 376 & 92 & 7 & 99 & 0.763 \\
\hline Ohio & 0 & 1 & 1 & -0.5 & 88 & 50 & 18 & 68 & 0.213 & 1042 & 0 & 2 & 2 & -1.250 \\
\hline Oklahoma & 0 & 0 & 0 & 0 & 77 & 61 & 19 & 80 & 0.284 & 565 & 184 & 50 & 234 & 0.667 \\
\hline Oregon & 0 & 0 & 0 & 0 & 36 & 0 & 0 & 0 & 0 & 323 & 0 & 0 & 0 & 0 \\
\hline Pennsylvania & 0 & 0 & 0 & 0 & 67 & 1 & 0 & 1 & 1 & 1383 & 0 & 0 & 0 & 0 \\
\hline Rhode Island & 0 & 0 & 0 & 0 & 4 & 0 & 0 & 0 & 0 & 27 & 0 & 0 & 0 & 0 \\
\hline $\begin{array}{c}\text { South } \\
\text { Carolina }\end{array}$ & 1 & 0 & 1 & 1 & 46 & 3 & 2 & 5 & 0.200 & 329 & 30 & 25 & 55 & 0.253 \\
\hline South Dakota & 0 & 0 & 0 & 0 & 66 & 0 & 0 & 0 & 0 & 335 & 146 & 66 & 212 & 0.436 \\
\hline Tennessee & 0 & 0 & 0 & 0 & 94 & 12 & 0 & 12 & 0.563 & 382 & 16 & 22 & 38 & -0.067 \\
\hline Texas & 0 & 0 & 0 & 0 & 254 & 3 & 1 & 4 & 0.375 & 1386 & 320 & 140 & 460 & 0.247 \\
\hline Utah & 1 & 1 & 2 & -0.025 & 29 & 6 & 0 & 6 & 0.283 & 273 & 34 & 60 & 94 & -0.059 \\
\hline Vermont & 1 & 0 & 1 & 1 & 14 & 0 & 0 & 0 & 0 & 118 & 17 & 3 & 20 & 0.211 \\
\hline Virginia & 1 & 0 & 1 & 0.5 & 130 & 0 & 0 & 0 & 0 & 400 & 0 & 0 & 0 & 0 \\
\hline Washington & 0 & 0 & 0 & 0 & 39 & 0 & 0 & 0 & 0 & 402 & 527 & 7 & 534 & 0.201 \\
\hline West Virginia & 0 & 0 & 0 & 0 & 55 & 0 & 0 & 0 & 0 & 364 & 1 & 0 & 1 & 1 \\
\hline Wisconsin & 0 & 0 & 0 & 0 & 72 & 5 & 0 & 5 & 0.500 & 709 & 0 & 0 & 0 & 0 \\
\hline Wyoming & 0 & 0 & 0 & 0 & 23 & 19 & 14 & 33 & 0.144 & 155 & 0 & 0 & 0 & 0 \\
\hline Total & $\overline{22}$ & 7 & 29 & 371 & 3121 & 583 & 371 & 959 & 0.19 & 24,273 & 3918 & 959 & 4877 & 0.387 \\
\hline
\end{tabular}

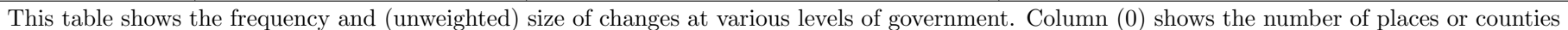

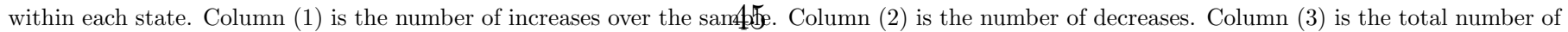
changes and column (4) is the average size of a change. 


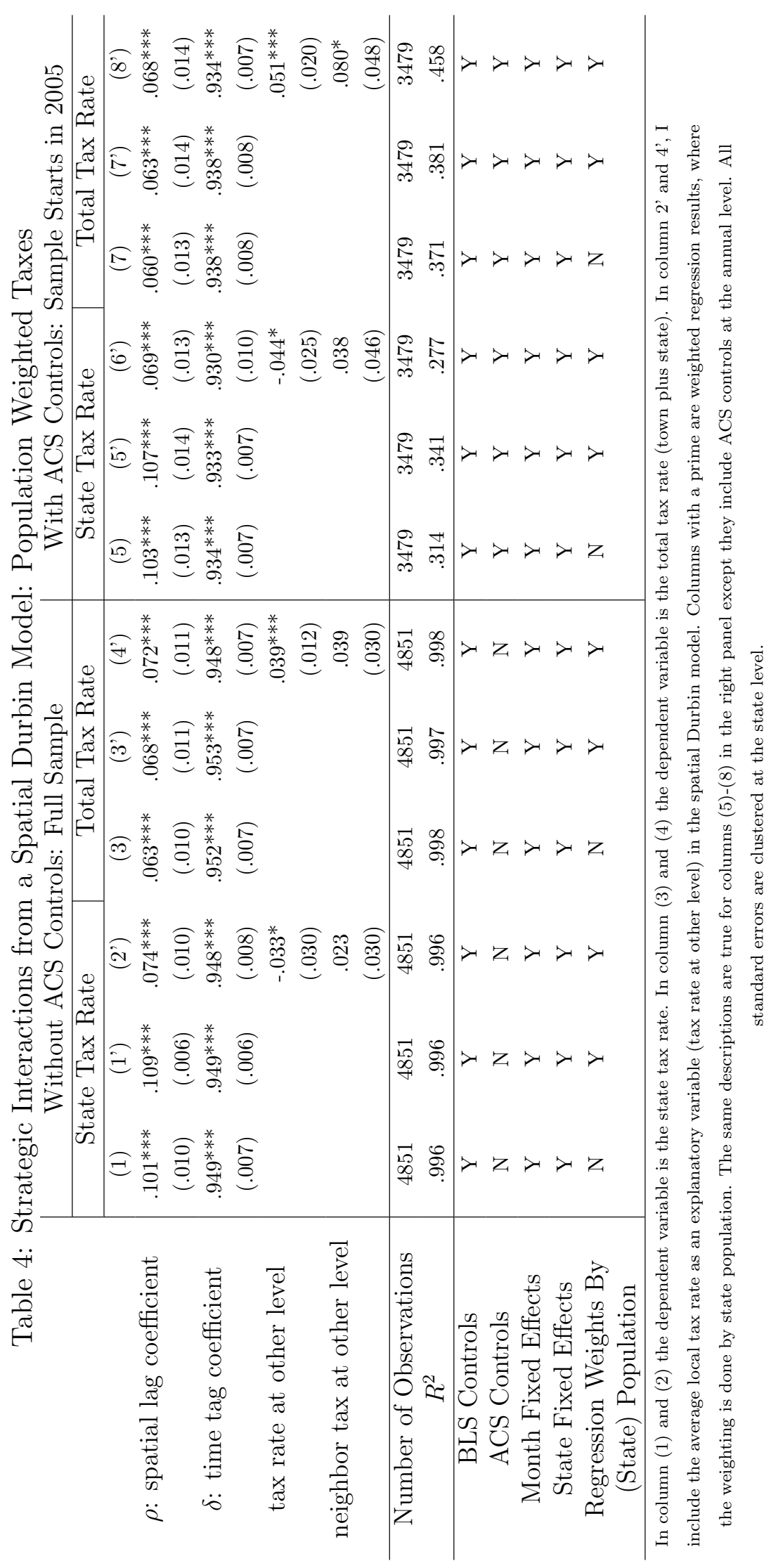




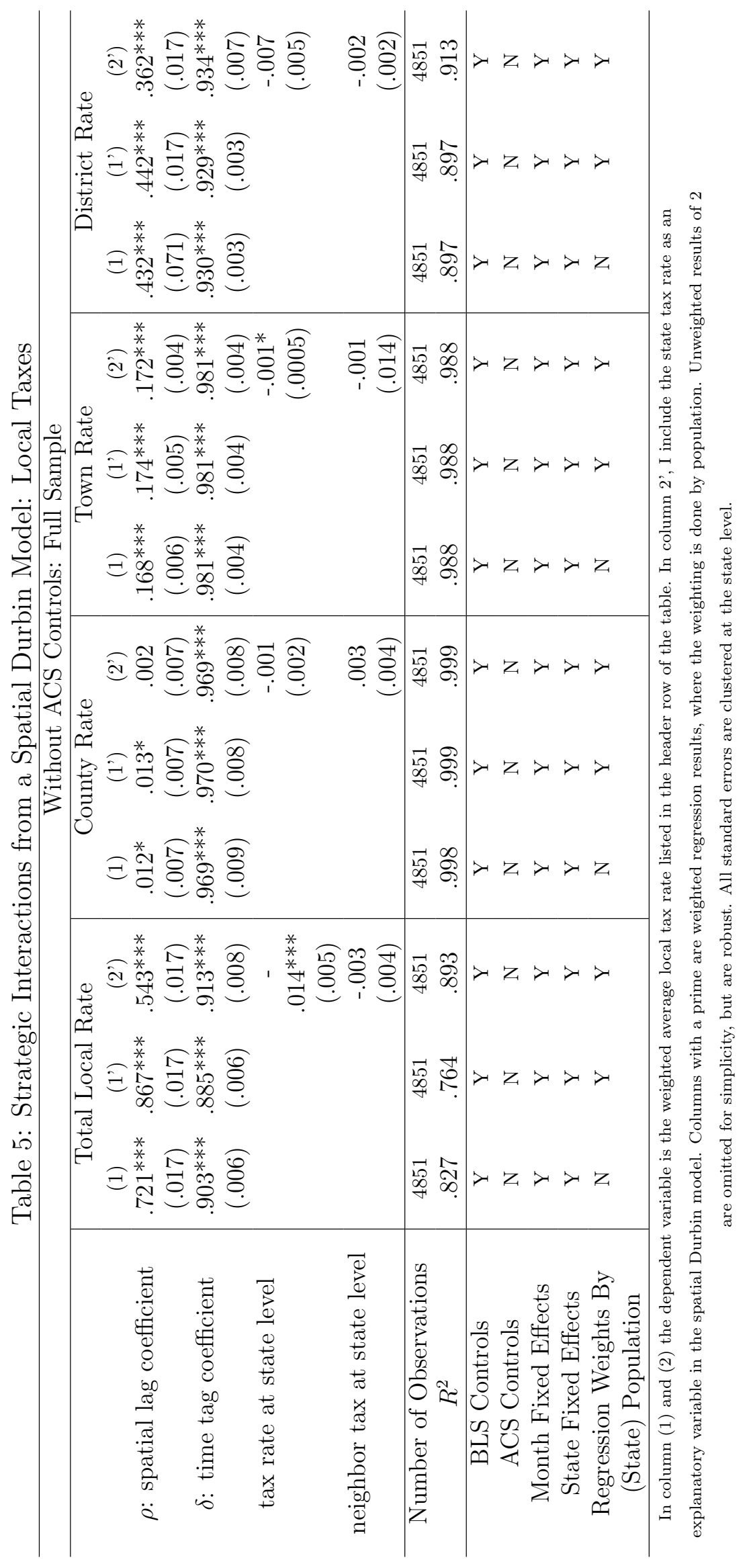




\section{Appendix (Online)}

\subsection{Data Appendix}

The tax rates in the database provided to me are delineated by the city name, state name, and five digit zip code. ProSales tax does not provide any map files of the data, so the data from over-lapping tax jurisdictions must be mapped using jurisdiction names. ProSales tax updates their database at the monthly frequency and the firm has been in existence since 2003; I have data starting in September 2003 and going until December 2011. The data set has a couple of gaps. ProSales tax did not publish or release data in 9/2005, 10/2005, 2/2007, 6/2007, 7/2007, 4/2008, and 8/2011. ${ }^{22}$

One limitation of the data is that the data do not contain unique Census FIPS codes to merge the tax data with Census data. As a result, I name merge each county and state to county names in the United States Census. The match rate at the county level is $99 \%{ }^{23}$ To match town names to local government identification codes, I match names in the tax data set to names of identified Census Places. ${ }^{24}$ When conducting the match, I require that the place name, county name, and state name must match. Because some local jurisdiction names may not correspond to Census Places, some "jurisdictions" in the tax data set remain unmatched. Because some people do not live in incorporated places, the remainder of county residents not living in a matched Census place are tabulated and are assigned the tax rate of the county in which they reside and are assigned the average tax rate of the remaining unmatched towns in the county. ${ }^{25}$ After name merging the tax data to Census Place and County codes, I can then merge the tax data with Census population data for each town and county.

In the United States, approximately 1000 cities and towns cross county borders. When this occurs, the town appears in my data set in multiple counties. I maintain all town-county pairs in the data set. I use ArcGIS to determine the population of the town in each county.

\footnotetext{
${ }^{22}$ When the data are missing and I wish to plot a monthly time series, I average across the months. For example, when reporting the number of tax changes each month, if one month is missing, I will report the number of tax changes in the following month divided by two.

${ }^{23}$ A couple of extremely sparsely populated counties in Alaska do not appear in the tax data set and the boroughs in New York City are treated as one entity in the tax data set.

${ }^{24} \mathrm{~A}$ Census Place may or may not correspond to incorporated municipal areas. Census Places include incorporated places (cities, towns and villages) in addition to Census Designated Places, which are populated areas that do not have a municipal government but that look like an incorporated places. Towns in the tax data set need not be a municipal incorporated place either. Thus, given by desire is to match population numbers to particular jurisdictions, matching to Census Places will not impose any identification problems.

${ }^{25}$ Because the fraction of people living in unincorporated places is relatively small, using the minimum tax rate of the unmatched entities in the tax data set will produce similar patterns.
} 
Using map files on the centroids of Census Blocks ${ }^{26} \mathrm{I}$ can calculate the Census Place and county that each Census Block is within. Once I assign each Census Block centroid to its county and place, I calculate the sum of the blocks' populations within each county that the place is within. Native American reservations are not specifically identified in the data set and the sales tax treatment on Native American reservations often differs by state; some reservations level reservation sales taxes. ${ }^{27}$

At the Census place level, the match rate is high. In 2010, $83 \%$ of Census places match to the tax data set; this is equivalent of matching $92 \%$ of the people who live in Census places to an observation in the tax data set. About $75 \%$ of people live in a Census place, which implies that approximately $70 \%$ of the United States population is matched to a town. The remainder of the unmatched population from the Census are matched to specific counties and are assumed to live in unincorporated areas. The fraction of the population that matches is actually better given that some cities do not appear as city governments. Table 6 shows that the match rate is low in states like Kentucky and Virginia, which have several large consolidated city-county governments that also appear as Census places. In the case of these consolidated governments, they are not matched at the place level, but rather at the county level.

Districts boundaries are often not stable over time. In some states, the data will code county tax rates as district tax rates. For example, in California, Pro Sales tax codes the uniform county tax rate as the county rate and codes additional county tax add ons as district tax rates. Its impossible to correct for this given that California also allows for special district taxes. In Georgia, ProSales Tax classified the county LOST at various times as district taxes and county taxes. The reason for this is that Georgia has a variety of different county LOST purposes. For the state of Georgia, I maintain their classifications. In Virginia, the uniform local tax rate is coded as a county rate in counties and as a city rate in consolidated city-counties. Again, I maintain the convention of the data set. The main reason for maintaining the classifications by the proprietary firm is consistency.

When district taxes are sub-municipal, the possibility exists that sales tax rates vary within a town. In these circumstances, I define the district tax rate as the the tax rate that appears in the most zip codes of the municipality. Such a measure is preferred for over-time comparisons because the average district tax rate in the town will change bot if zip code

\footnotetext{
${ }^{26} \mathrm{~A}$ Census block is the smallest level of Census geography in the United States.

${ }^{27}$ Although the tax treatment of sales to non-tribal members often varies by state, most courts have ruled that sales to non-tribal members require tax collections. This is the opposite of court rulings on excise taxes, where courts have ruled that tribal nations need not collect state excise taxes under most circumstances. For a discussion of tribal regulations see "Piecing Together the State-Tribal Tax Puzzle" by the National Conference of State Legislatures.
} 
boundaries change or if district boundaries shift across zip codes; in fact, district boundaries are relatively unstable over time. Given that district taxes are relatively uncommon and small, the results are similar if the mean district tax rate or the minimum district tax rate is used. In fact, given that sub-municipal district tax rates are most common in the largest cities, the most common district tax rate is usually zero. In cases where the district is larger than the municipality, the district tax rate is common to the municipality.

The text of the paper then creates weighted averages and variances across jurisdictions indexed by $i$. Given the technical discussion above, note that for each county that a town is in, $i$ will take on a different value. Note further that the residual population of a county not matched to a Census place will appear as one $i$ observation for each county. For the residual unmatched population living in unincorporated towns, $\tau_{i, k, t}$ is the average tax rate of the named (but unmatched) places in the tax data set and $p_{i, j, k}$ is the residual unmatched population within the county. I define $i$ in this manner to avoid having to take a double summation over counties.

\subsection{Derivation of Variance}

Because equation 5 uses population weights and not frequency rates, the formula is nonstandard. Equation 5 can be derived as follows. Let $w_{i}=\frac{p_{i}}{\sum_{i \in \Theta_{k}} p_{i}}$ be the weights, where $p_{i}$ is towni's population. The estimated (weighted) variance is

$$
\hat{\operatorname{Var}}\left(\tau_{i, k, t}\right)=\frac{\sum_{i \in \Theta_{k}} w_{i}}{\left(\sum_{i \in \Theta_{k}} w_{i}\right)^{2}-\sum_{i \in \Theta_{k}} w_{i}^{2}} \cdot \sum_{i \in \Theta_{k}} w_{i}\left(\tau_{i, k, t}-\bar{\tau}_{k, t}\right)^{2} .
$$

Because the weights sum to one, this works out to be

$$
\hat{\operatorname{Var}}\left(\tau_{i, k, t}\right)=\frac{1}{1-\sum_{i \in \Theta_{k}} w_{i}^{2}} \cdot \sum_{i \in \Theta_{k}} w_{i}\left(\tau_{i, k, t}-\bar{\tau}_{k, t}\right)^{2}
$$


Substituting in $w_{i}=\frac{p_{i}}{\sum_{i \in \Theta_{k}} p_{i}}$ yields

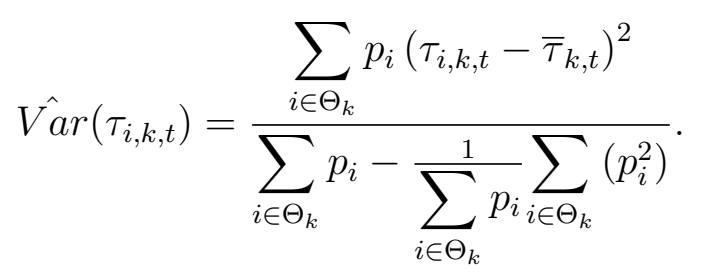

\subsection{Legal Discussions on the Authority of Local Governments}

Schragger (2001) defines Dillon's Rule in footnote 311:

The standard view is that municipal corporations are "instrumentalities of the state," see EUGENE MCQUILLIN, THE LAW OF MUNICIPAL CORPORATIONS $\S 1.58$ (3d ed. rev. 1987), and have no sovereign status independent of the state. Thus, the state legislature could alter or eliminate municipalities at any time, like any other agency of the state. The view that local governments are instruments of the state is traced to John F. Dillon's 1872 Treatise on Municipal Corporations, in which Dillon asserted that "[a]ll corporations, public and private, exist and can exist only by virtue of express legislative enactment, creating or authorizing the creating of the corporate body." JOHN F. DILLON, A TREATISE ON THE LAW OF MUNICIPAL CORPORATIONS 52 (1872). "Municipal corporations are created by legislative act." .... What has become known as "Dillon's Rule" - that state enabling statutes are to be strictly construed... is the accepted wisdom today.

In an article mainly about Mayors, Schragger (2006) has some useful discussion about the powers and authorities of municipalities vis-à-vis states. For example, on page 2556:

One of the challenges in assessing the relative power of cities is the contradictory legal status of local governments. Because cities are constitutionally subordinate to states, states are in a position to limit cities' formal powers and often do so. Nevertheless, in most states, cities do have some degree of local autonomy. That autonomy is protected under state constitutions that mimic the state-federal relationship by carving out a separate sphere of authority for local governments. The city thus enjoys a contradictory legal status: It is an instrumentality of the state but it is also politically autonomous within its sphere - it is an administrative unit as well as a minisovereign. 
The ongoing debates in the legal literature concerning the relative power or powerlessness of the city reflect this dual status. Those who emphasize city power argue that certain localities, especially suburban ones, exercise significant local autonomy in areas in which they are deemed locally sovereign, mostly those activities that implicate land use, education, and local health and welfare. By contrast, scholars who emphasize city powerlessness point to the fact that local governments are instrumentalities of their states and enjoy no independent legal status protected by the Constitution. Unlike private corporations, which exercise the autonomy that all private persons may exercise, municipal corporations exercise power at the state's sufferance. These conceptual and descriptive accounts of local power can co-exist. As a formal matter, cities in the United States enjoy a significant amount of legal autonomy, at least as compared with cities in some other western democracies. Local officials are normally elected by the local electorate, not appointed by a central government. Local governments usually have taxing authority (though it is limited) and thus are not entirely dependent on grants from higher-level governments. And local governments can generally make decisions about what to spend monies on (though again, the state requires certain kinds of expenditures).

Cohn (1957) writes about home rule and shows large differences across states:

Constitutional home rule in Michigan has produced no municipal autonomy in the sense envisioned by its proponents. The tax powers of its municipalities must find their source in legislative enactments, not in the constitution. The taxing power is an attribute of state sovereignty. The power of local self-government is confined within the limits established by the legislature. In this respect, therefore, Michigan cities stand in the same relationship to the state government as do the cities in states which provide no constitutional sanction for the exercise of powers of local self-determination.

In Mouledoux $v$. Maestri, a New Orleans sales and use tax ordinance levied by legislative authorization in the form of an amendment to the city charter, was challenged as a surrender of the state's taxing power. In sustaining the tax, the Louisiana Supreme Court said: "Clearly, the legislature in conferring taxing power upon the city has not surrendered its taxing power because it can revoke the power entrusted to the city or modify it at its pleasure."

Decisions in the non-property tax area point strongly to the conclusion that legislative authority is required to support municipal levies. Legislative provisions 
further preclude or limit the imposition of particular municipal taxes.

\subsection{Additional Tables and Figures}

The appendix shows some similar figures and tables as the text using different weighting schemes or data restrictions. Each of the figures and tables is described in the text of the paper. The appendix is for online publication only.

The first two figures show time trends in the data. Unlike the tables in the text, which restrict the sample to only states that allow for LOST at at least one level of government, these two figures calculate the weighted average across all towns in the United States including towns and counties that do not have LOST and including towns in states with no state sales tax rate.

The maps show changes in each type of local sales tax over the sample period. In all maps, the weight averages are constructed at the county level.

Table 7 shows the weighted average of tax rates and standard deviations by state for December 2011 using population numbers from the 2000 Census as weights. All tables in the text use 2010 population data as weights. Table 8 shows the unweighted averages where all towns and counties within a state are treated equally. Table 9 to 15 show all of the years in between the years reported in the text - where the weights are based on 2010 population weights.

The last two tables relate to the application of the data to tax competition using a spatial panel model. The first table shows the summary statistics of the variables used in the regressions. The last table shows the econometric results using the unweighted average of local tax rates in a state. Using the state tax rate and the total tax rate as dependent variables yield similar results. Intuitively, states are unlikely to care about the unweighted average of tax rates within their state; most towns are small and these results give disproportionate weight to very small towns in the state. The state will most likely be concerned with large jurisdictions where the tax base is sufficiently large to interest state policy makers. 
Figure 18: Tax Rates over Time
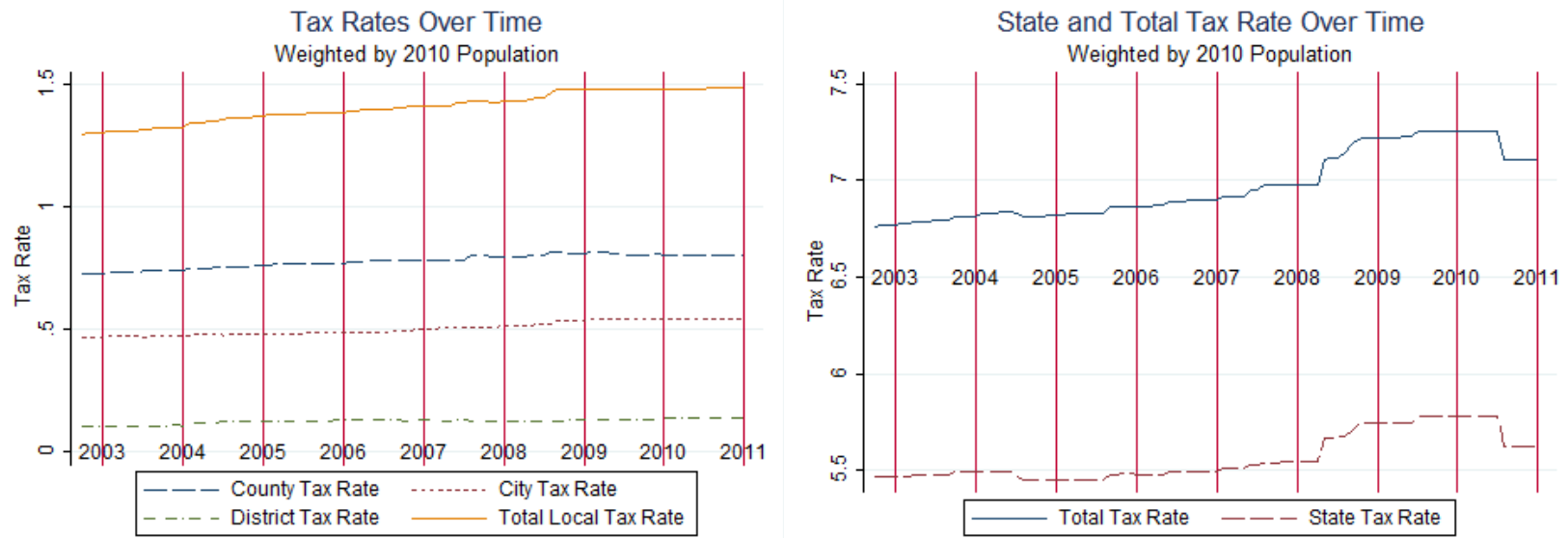

These figures show how the weighted average of tax rates have evolved over time using data at the monthly frequency. The

averages include all towns in the United States - including both state with and without LOST - so that they can be interpreted as the weighted average across all towns and counties in the United States. The left figure looks at the time series properties of only local rates, while the right figure looks at the state rates and the total (state + local rates).

Figure 19: Standard Deviations over Time
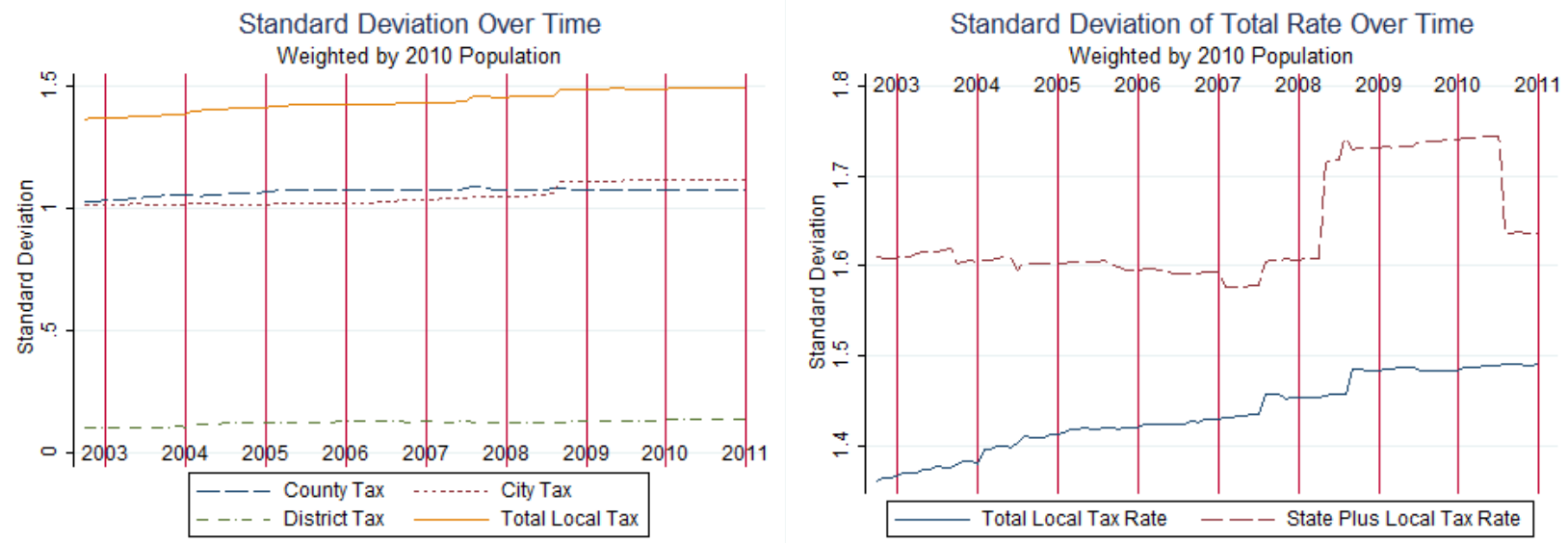

These figures show how the weighted average of the standard deviation of tax rates have evolved over time using data at the monthly frequency. The averages include all towns in the United States - including both state with and without LOST - so that they can be interpreted as the weighted average across all towns and counties in the United States. The left figure looks at the time series properties of only local rates, while the right figure looks at the state rates and the total (state + local rates). 
Figure 20: County Tax Changes, 2003 to 2011

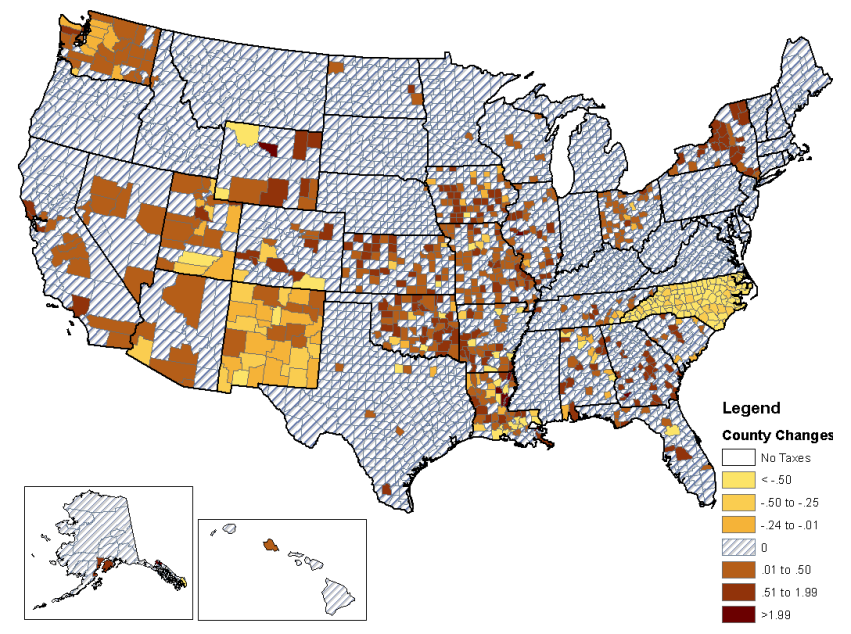

This figure shows changes in county tax rates from 2003 to 2011. In states where county tax rates are different within a county, the population weighted average is used. Hashed counties are counties where county tax rates are the same in 2011 as they were in 2003. Hallow counties are counties in states with no county tax rates. Darker colors imply larger tax increases and lighter colors imply larger tax decreases.

Figure 21: District Tax Changes, 2003 to 2011

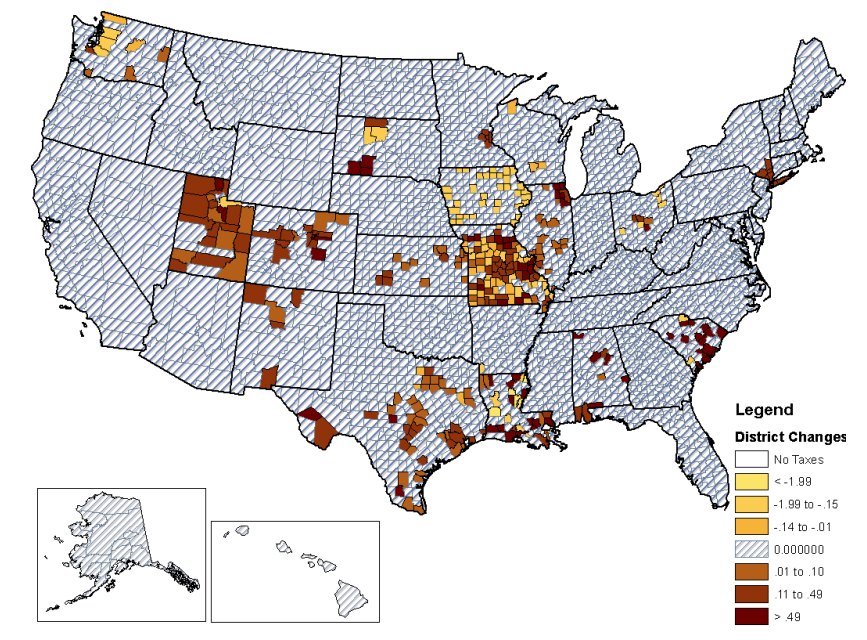

This figure shows changes in the population weighted district tax rates from 2003 to 2011. Population weights are use to aggregate up district taxes to the county level. Hashed counties are counties where the weighted district tax rates are the same in 2011 as they were in 2003. Hallow counties are counties in states with no district tax rates. Darker colors imply larger tax increases and lighter colors imply larger tax decreases. 
Figure 22: Town Tax Changes, 2003 to 2011

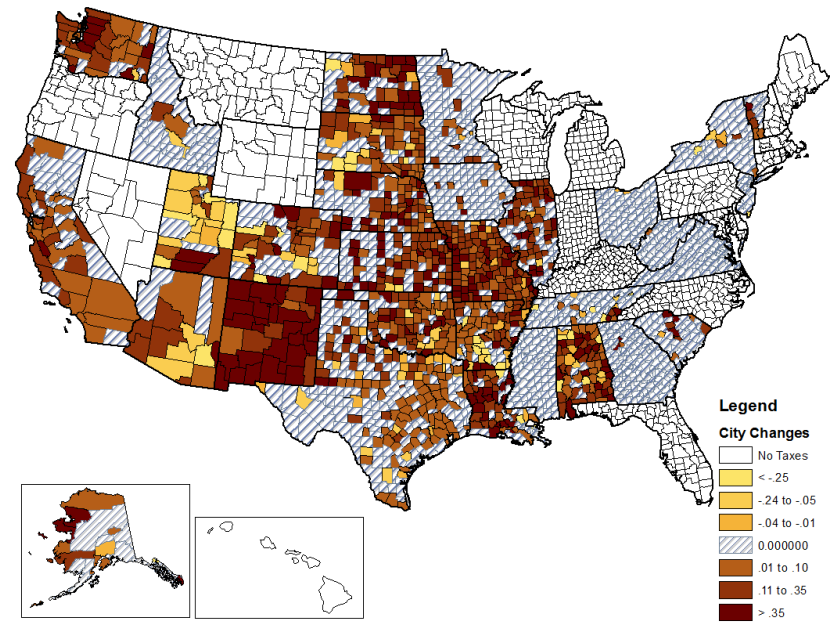

This figure shows changes in the population weighted town tax rates from 2003 to 2011. Population weights are use to aggregate up town taxes to the county level. Hashed counties are counties where town tax rates are the same in 2011 as they were in 2003. Hallow counties are counties in states with no sales tax rates at

the town level. Darker colors imply larger tax increases and lighter colors imply larger tax decreases.

Figure 23: Total LOST (Town, County and District) Tax Changes, 2003 to 2011

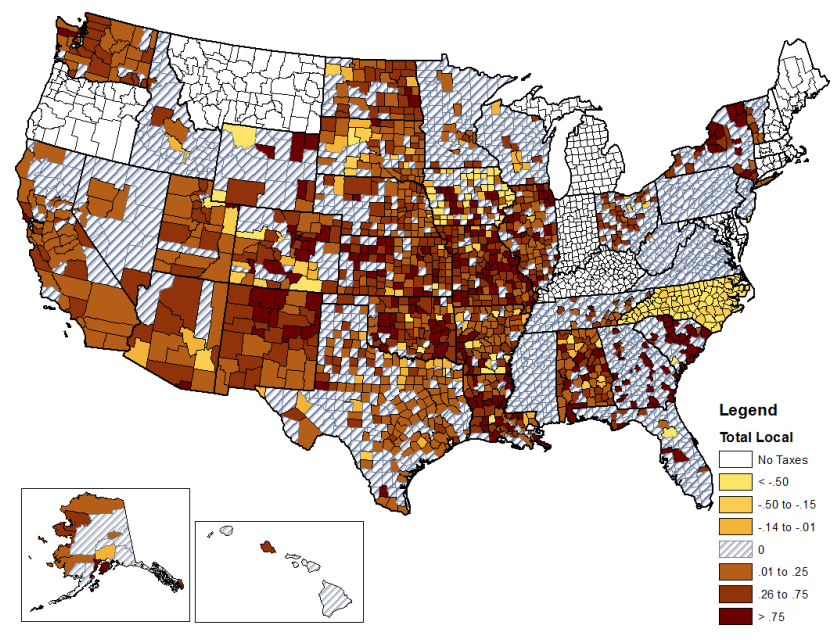

This figure shows changes in the total LOST (each county's population weighted county, town, and district tax rates) from 2003 to 2011. Hashed counties are counties where LOST rates are the same in 2011 as they were in 2003. Hallow counties are counties in states with no LOST (at any level of local government).

Darker colors imply larger tax increases and lighter colors imply larger tax decreases. 
Table 6: Stats Regarding Matching

\begin{tabular}{|c|c|c|c|c|c|c|}
\hline State & $\begin{array}{c}(1) \# \\
\text { Counties }\end{array}$ & $\begin{array}{l}\text { (2) \# Census } \\
\text { Places }\end{array}$ & $\begin{array}{l}\text { (3) Fraction } \\
\text { of Places } \\
\text { Matched }\end{array}$ & $\begin{array}{l}\text { (4) Fraction } \\
\text { of Place } \\
\text { Populations } \\
\text { Matched }\end{array}$ & $\begin{array}{c}\text { (5) Fraction } \\
\text { of State } \\
\text { Population in } \\
\text { a Place }\end{array}$ & $\begin{array}{c}(6) \\
\text { Population in } \\
\text { Census Places }\end{array}$ \\
\hline Alabama & 67 & 476 & 82.35 & 94.88 & 64.59 & $3,087,299$ \\
\hline Alaska & 24 & 288 & 81.13 & 90.01 & 97.12 & 689,802 \\
\hline Arizona & 15 & 205 & 45.45 & 91.75 & 92.57 & $5,917,349$ \\
\hline Arkansas & 75 & 498 & 92.05 & 97.91 & 66.57 & $1,941,247$ \\
\hline California & 58 & 1152 & 75.64 & 95.11 & 94.44 & $35,184,224$ \\
\hline Colorado & 63 & 333 & 72.71 & 91.08 & 85.52 & $4,300,887$ \\
\hline Connecticut & 8 & 104 & 73.24 & 93.34 & 60.97 & $2,179,271$ \\
\hline Delaware & 3 & 58 & 76.32 & 78.48 & 43.25 & 388,366 \\
\hline District of Columbia & 1 & 1 & 100 & 100 & 100 & 601,723 \\
\hline Florida & 67 & 574 & 62.39 & 81.62 & 76.07 & $14,302,527$ \\
\hline Georgia & 156 & 543 & 87.02 & 87.04 & 45.99 & $4,454,901$ \\
\hline Hawaii & 4 & 66 & 43.71 & 40.25 & 96.12 & $1,307,487$ \\
\hline Idaho & 44 & 195 & 85.9 & 78.7 & 69.99 & $1,097,112$ \\
\hline Illinois & 102 & 1331 & 97.37 & 99.43 & 87.58 & $11,236,726$ \\
\hline Indiana & 92 & 614 & 90.16 & 97.95 & 68.07 & $4,413,508$ \\
\hline Iowa & 99 & 993 & 98.41 & 99.71 & 79.5 & $2,421,895$ \\
\hline Kansas & 105 & 656 & 97.76 & 99.72 & 83.2 & $2,373,862$ \\
\hline Kentucky & 119 & 421 & 80.34 & 59.6 & 57.45 & $2,492,792$ \\
\hline Louisiana & 64 & 422 & 89.22 & 92.48 & 65.6 & $2,974,010$ \\
\hline Maine & 16 & 122 & 93.13 & 96.88 & 46.62 & 619,334 \\
\hline Maryland & 24 & 334 & 64.48 & 81.49 & 82.27 & $4,750,167$ \\
\hline Massachusetts & 14 & 194 & 79.51 & 88.96 & 70.49 & $4,615,402$ \\
\hline Michigan & 83 & 619 & 89.45 & 97.08 & 55.92 & $5,526,809$ \\
\hline Minnesota & 87 & 842 & 92.94 & 99.2 & 82.23 & $4,361,592$ \\
\hline Mississippi & 82 & 319 & 88.12 & 95.81 & 54.74 & $1,624,318$ \\
\hline Missouri & 115 & 973 & 94.28 & 97.96 & 69.67 & $4,172,598$ \\
\hline Montana & 55 & 276 & 75.82 & 84.03 & 69.1 & 683,694 \\
\hline Nebraska & 93 & 548 & 94.48 & 98.47 & 77.57 & $1,416,720$ \\
\hline Nevada & 17 & 100 & 77.52 & 67.39 & 94.4 & $2,549,441$ \\
\hline New Hampshire & 10 & 87 & 90.63 & 97.28 & 47.53 & 625,697 \\
\hline New Jersey & 21 & 441 & 80.92 & 92.51 & 59.94 & $5,270,245$ \\
\hline New Mexico & 33 & 249 & 56.21 & 86.66 & 82.24 & $1,693,431$ \\
\hline New York & 58 & 1043 & 87.72 & 96.65 & 81.06 & $15,707,938$ \\
\hline North Carolina & 100 & 627 & 84.84 & 95.51 & 58.79 & $5,606,107$ \\
\hline North Dakota & 53 & 376 & 93.77 & 99.04 & 77.93 & 524,124 \\
\hline Ohio & 88 & 1042 & 86.54 & 95.38 & 70.15 & $8,093,400$ \\
\hline Oklahoma & 77 & 565 & 77.08 & 97.62 & 77.72 & $2,915,617$ \\
\hline Oregon & 36 & 323 & 85.68 & 94.66 & 78.96 & $3,025,205$ \\
\hline Pennsylvania & 67 & 1383 & 78.4 & 90.67 & 55.77 & $7,083,831$ \\
\hline Rhode Island & 4 & 27 & 79.41 & 94.81 & 61.52 & 647,541 \\
\hline South Carolina & 46 & 329 & 83.29 & 85.23 & 46.08 & $2,131,422$ \\
\hline South Dakota & 66 & 335 & 85.9 & 95.87 & 75.24 & 612,602 \\
\hline Tennessee & 94 & 382 & 89.25 & 81.66 & 61.77 & $3,920,218$ \\
\hline Texas & 254 & 1386 & 79.11 & 97.32 & 78.35 & $19,700,488$ \\
\hline Utah & 29 & 273 & 83.74 & 94.69 & 95.41 & $2,636,987$ \\
\hline Vermont & 14 & 118 & 99.16 & 99.75 & 38.61 & 241,585 \\
\hline Virginia & 130 & 400 & 67.68 & 76.92 & 67.91 & $5,433,225$ \\
\hline Washington & 39 & 402 & 64.01 & 81.06 & 81.91 & $5,508,054$ \\
\hline West Virginia & 55 & 364 & 90.77 & 90.57 & 43.41 & 804,460 \\
\hline Wisconsin & 72 & 709 & 91.72 & 97.74 & 73.02 & $4,152,569$ \\
\hline Wyoming & 23 & 155 & 76.35 & 91.21 & 77.61 & 437,432 \\
\hline Total & 3121 & 24,273 & 82.95 & 91.95 & 74 & $228,457,241$ \\
\hline
\end{tabular}

The first two columns show the number of counties and places by state. The third column shows the fraction of 2010 Census Places I matched to the tax data.

Column (4) shows the fraction of people living in Census places that I can match. Column (5) is the fraction of the state population living in a Census place. The final column is the total population in a Census place. 
Table 7: Tax Rates and SDs for December 2011 with 2000 Population Weights

\begin{tabular}{|c|c|c|c|c|c|c|c|c|c|c|}
\hline State & State Rate & Total Local & County & Town & District & Total & sd(Total Local) & sd(County) & sd(Town) & sd(District) \\
\hline Alabama & 4 & 3.978 & 1.599 & 2.161 & 0.218 & 7.978 & 1.57 & 0.99 & 1.714 & 0.434 \\
\hline Alaska & 0 & 1.248 & 0.607 & 0.642 & 0 & 1.248 & 2.35 & 1.614 & 1.758 & 0 \\
\hline Arizona & 6.6 & 2.284 & 0.687 & 1.597 & 0 & 8.884 & 0.883 & 0.193 & 0.85 & 0 \\
\hline Arkansas & 6 & 2.104 & 1.253 & 0.851 & 0 & 8.104 & 0.965 & 0.553 & 0.834 & 0 \\
\hline California & 7.25 & 0.889 & 0.83 & 0.059 & 0 & 8.139 & 0.55 & 0.543 & 0.184 & 0 \\
\hline Colorado & 2.9 & 3.919 & 0.713 & 2.403 & 0.803 & 6.819 & 1.509 & 0.621 & 1.505 & 0.552 \\
\hline Connecticut & 6.35 & 0 & 0 & 0 & 0 & 6.35 & 0 & 0 & 0 & 0 \\
\hline Delaware & 0 & 0 & 0 & 0 & 0 & 0 & 0 & 0 & 0 & 0 \\
\hline District of Columbia & 6 & 0 & 0 & 0 & 0 & 6 & 0 & 0 & 0 & 0 \\
\hline Florida & 6 & 0.653 & 0.653 & 0 & 0 & 6.653 & 0.475 & 0.475 & 0 & 0 \\
\hline Georgia & 4 & 2.845 & 2.794 & 0.051 & 0 & 6.845 & 0.487 & 0.408 & 0.222 & 0 \\
\hline Hawaii & 4 & 0.362 & 0.362 & 0 & 0 & 4.362 & 0.268 & 0.268 & 0 & 0 \\
\hline Idaho & 6 & 0.022 & 0.014 & 0.007 & 0 & 6.022 & 0.13 & 0.086 & 0.099 & 0 \\
\hline Illinois & 6.25 & 2.058 & 0.68 & 0.744 & 0.634 & 8.308 & 1.262 & 0.591 & 0.576 & 0.455 \\
\hline Indiana & 7 & 0 & 0 & 0 & 0 & 7 & 0 & 0 & 0 & 0 \\
\hline Iowa & 6 & 0.822 & 0.814 & 0.008 & 0 & 6.822 & 0.379 & 0.385 & 0.087 & 0 \\
\hline Kansas & 6.3 & 1.815 & 1.03 & 0.772 & 0.012 & 8.115 & 0.721 & 0.371 & 0.679 & 0.048 \\
\hline Kentucky & 6 & 0 & 0 & 0 & 0 & 6 & 0 & 0 & 0 & 0 \\
\hline Louisiana & 4 & 4.684 & 2.395 & 1.706 & 0.583 & 8.684 & 0.651 & 2.16 & 2.29 & 1.276 \\
\hline Maine & 5 & 0 & 0 & 0 & 0 & 5 & 0 & 0 & 0 & 0 \\
\hline Maryland & 6 & 0 & 0 & 0 & 0 & 6 & 0 & 0 & 0 & 0 \\
\hline Massachusetts & 6.25 & 0 & 0 & 0 & 0 & 6.25 & 0 & 0 & 0 & 0 \\
\hline Michigan & 6 & 0 & 0 & 0 & 0 & 6 & 0 & 0 & 0 & 0 \\
\hline Minnesota & 6.875 & 0.284 & 0.035 & 0.122 & 0.126 & 7.159 & 0.302 & 0.071 & 0.236 & 0.126 \\
\hline Mississippi & 7 & 0.003 & 0 & 0.003 & 0 & 7.003 & 0.027 & 0 & 0.027 & 0 \\
\hline Missouri & 4.225 & 3.308 & 1.29 & 1.53 & 0.488 & 7.533 & 1.011 & 0.491 & 1.11 & 0.585 \\
\hline Montana & 0 & 0 & 0 & 0 & 0 & 0 & 0 & 0 & 0 & 0 \\
\hline Nebraska & 5.5 & 1.046 & 0.002 & 1.043 & 0 & 6.546 & 0.683 & 0.036 & 0.686 & 0 \\
\hline Nevada & 4.6 & 3.304 & 3.262 & 0 & 0.042 & 7.904 & 0.374 & 0.41 & 0 & 0.102 \\
\hline New Hampshire & 0 & 0 & 0 & 0 & 0 & 0 & 0 & 0 & 0 & 0 \\
\hline New Jersey & 7 & 0 & 0 & 0 & 0 & 7 & 0 & 0 & 0 & 0 \\
\hline New Mexico & 5.125 & 2.137 & 0.301 & 1.782 & 0.054 & 7.262 & 0.97 & 0.503 & 1.228 & 0.167 \\
\hline New York & 4 & 4.479 & 2.231 & 1.997 & 0.251 & 8.479 & 0.531 & 2.217 & 2.435 & 0.195 \\
\hline North Carolina & 4.75 & 2.1 & 2.057 & 0 & 0.043 & 6.85 & 0.162 & 0.106 & 0 & 0.141 \\
\hline North Dakota & 5 & 1.206 & 0.12 & 1.086 & 0 & 6.206 & 0.944 & 0.219 & 0.867 & 0 \\
\hline Ohio & 5.5 & 1.292 & 1.281 & 0 & 0.011 & 6.792 & 0.46 & 0.467 & 0 & 0.097 \\
\hline Oklahoma & 4.5 & 3.436 & 0.732 & 2.704 & 0 & 7.936 & 1.336 & 0.572 & 1.515 & 0 \\
\hline Oregon & 0 & 0 & 0 & 0 & 0 & 0 & 0 & 0 & 0 & 0 \\
\hline Pennsylvania & 6 & 0.351 & 0.351 & 0 & 0 & 6.351 & 0.698 & 0.698 & 0 & 0 \\
\hline Rhode Island & 7 & 0 & 0 & 0 & 0 & 7 & 0 & 0 & 0 & 0 \\
\hline South Carolina & 6 & 1.157 & 0.276 & 0.26 & 0.62 & 7.157 & 0.847 & 0.443 & 0.473 & 0.627 \\
\hline South Dakota & 4 & 1.634 & 0 & 1.47 & 0.164 & 5.634 & 0.971 & 0 & 0.86 & 0.756 \\
\hline Tennessee & 7 & 2.419 & 2.388 & 0.031 & 0 & 9.419 & 0.244 & 0.323 & 0.249 & 0 \\
\hline Texas & 6.25 & 1.625 & 0.137 & 1.051 & 0.437 & 7.875 & 0.641 & 0.225 & 0.652 & 0.447 \\
\hline Utah & 4.7 & 1.977 & 1.091 & 0.301 & 0.585 & 6.677 & 0.302 & 0.448 & 0.463 & 0.296 \\
\hline Vermont & 6 & 0.155 & 0 & 0.155 & 0 & 6.155 & 0.342 & 0 & 0.342 & 0 \\
\hline Virginia & 4 & 1 & 0.693 & 0.307 & 0 & 5 & 0 & 0.454 & 0.454 & 0 \\
\hline Washington & 6.5 & 2.219 & 0.32 & 1.675 & 0.224 & 8.719 & 0.605 & 0.578 & 1.129 & 0.509 \\
\hline West Virginia & 6 & 0.002 & 0 & 0.002 & 0 & 6.002 & 0.041 & 0 & 0.041 & 0 \\
\hline Wisconsin & 5 & 0.426 & 0.374 & 0 & 0.053 & 5.426 & 0.202 & 0.219 & 0 & 0.106 \\
\hline Wyoming & 4 & 1.418 & 1.418 & 0 & 0 & 5.418 & 0.73 & 0.73 & 0 & 0 \\
\hline US & 5.63 & 1.484 & 0.81 & 0.538 & 0.136 & 7.114 & 1.512 & 1.087 & 1.124 & 0.357 \\
\hline
\end{tabular}

The first six numerical columns present the weighted average of the state, total local (county + town + district), county, town, district, and total combined tax rates. The final four 
Table 8: Tax Rates and SDs for December 2011: Unweighted

\begin{tabular}{|c|c|c|c|c|c|c|c|c|c|c|}
\hline State & State Rate & Total Local & County & Town & District & Total & sd(Total Local) & sd(County) & sd(Town) & sd(District) \\
\hline Alabama & 4 & 4.033 & 1.762 & 2.155 & 0.116 & 8.033 & 1.385 & 0.968 & 1.455 & 0.326 \\
\hline Alaska & 0 & 1.423 & 0.505 & 0.918 & 0 & 1.423 & 1.885 & 1.211 & 1.632 & 0 \\
\hline Arizona & 6.6 & 1.78 & 0.734 & 1.046 & 0 & 8.38 & 1.329 & 0.308 & 1.263 & 0 \\
\hline Arkansas & 6 & 2.078 & 1.374 & 0.704 & 0 & 8.078 & 0.951 & 0.592 & 0.81 & 0 \\
\hline California & 7.25 & 0.504 & 0.464 & 0.041 & 0 & 7.754 & 0.508 & 0.487 & 0.157 & 0 \\
\hline Colorado & 2.9 & 3.048 & 1 & 1.772 & 0.276 & 5.948 & 1.803 & 0.919 & 1.585 & 0.482 \\
\hline Connecticut & 6.35 & 0 & 0 & 0 & 0 & 6.35 & 0 & 0 & 0 & 0 \\
\hline Delaware & 0 & 0 & 0 & 0 & 0 & 0 & 0 & 0 & 0 & 0 \\
\hline District of Columbia & 6 & 0 & 0 & 0 & 0 & 6 & 0 & 0 & 0 & 0 \\
\hline Florida & 6 & 0.731 & 0.731 & 0 & 0 & 6.731 & 0.463 & 0.463 & 0 & 0 \\
\hline Georgia & 4 & 2.936 & 2.934 & 0.003 & 0 & 6.936 & 0.255 & 0.249 & 0.052 & 0 \\
\hline Hawaii & 4 & 0.129 & 0.129 & 0 & 0 & 4.129 & 0.22 & 0.22 & 0 & 0 \\
\hline Idaho & 6 & 0.045 & 0.01 & 0.035 & 0 & 6.045 & 0.261 & 0.071 & 0.253 & 0 \\
\hline Illinois & 6.25 & 0.718 & 0.338 & 0.172 & 0.207 & 6.968 & 0.879 & 0.465 & 0.382 & 0.373 \\
\hline Indiana & 7 & 0 & 0 & 0 & 0 & 7 & 0 & 0 & 0 & 0 \\
\hline Iowa & 6 & 0.931 & 0.916 & 0.015 & 0 & 6.931 & 0.25 & 0.274 & 0.121 & 0 \\
\hline Kansas & 6.3 & 1.35 & 0.974 & 0.37 & 0.007 & 7.65 & 0.696 & 0.52 & 0.575 & 0.041 \\
\hline Kentucky & 6 & 0 & 0 & 0 & 0 & 6 & 0 & 0 & 0 & 0 \\
\hline Louisiana & 4 & 4.584 & 2.025 & 2.113 & 0.446 & 8.584 & 0.835 & 2.096 & 2.374 & 1.231 \\
\hline Maine & 5 & 0 & 0 & 0 & 0 & 5 & 0 & 0 & 0 & 0 \\
\hline Maryland & 6 & 0 & 0 & 0 & 0 & 6 & 0 & 0 & 0 & 0 \\
\hline Massachusetts & 6.25 & 0 & 0 & 0 & 0 & 6.25 & 0 & 0 & 0 & 0 \\
\hline Michigan & 6 & 0 & 0 & 0 & 0 & 6 & 0 & 0 & 0 & 0 \\
\hline Minnesota & 6.875 & 0.056 & 0.01 & 0.015 & 0.031 & 6.931 & 0.145 & 0.064 & 0.087 & 0.083 \\
\hline Mississippi & 7 & 0.001 & 0 & 0.001 & 0 & 7.001 & 0.012 & 0 & 0.012 & 0 \\
\hline Missouri & 4.225 & 2.658 & 1.434 & 0.967 & 0.258 & 6.883 & 0.993 & 0.453 & 0.864 & 0.399 \\
\hline Montana & 0 & 0 & 0 & 0 & 0 & 0 & 0 & 0 & 0 & 0 \\
\hline Nebraska & 5.5 & 0.377 & 0.004 & 0.373 & 0 & 5.877 & 0.577 & 0.044 & 0.578 & 0 \\
\hline Nevada & 4.6 & 2.721 & 2.683 & 0 & 0.038 & 7.321 & 0.441 & 0.413 & 0 & 0.091 \\
\hline New Hampshire & 0 & 0 & 0 & 0 & 0 & 0 & 0 & 0 & 0 & 0 \\
\hline New Jersey & 7 & 0 & 0 & 0 & 0 & 7 & 0 & 0 & 0 & 0 \\
\hline New Mexico & 5.125 & 1.643 & 0.688 & 0.947 & 0.008 & 6.768 & 0.786 & 0.625 & 1.199 & 0.062 \\
\hline New York & 4 & 4.106 & 3.924 & 0.045 & 0.137 & 8.106 & 0.453 & 0.527 & 0.354 & 0.181 \\
\hline North Carolina & 4.75 & 2.059 & 2.054 & 0 & 0.005 & 6.809 & 0.112 & 0.103 & 0 & 0.051 \\
\hline North Dakota & 5 & 0.496 & 0.064 & 0.432 & 0 & 5.496 & 0.743 & 0.178 & 0.72 & 0 \\
\hline Ohio & 5.5 & 1.302 & 1.298 & 0 & 0.004 & 6.802 & 0.357 & 0.361 & 0 & 0.069 \\
\hline Oklahoma & 4.5 & 3.673 & 1.085 & 2.588 & 0 & 8.173 & 1.476 & 0.585 & 1.477 & 0 \\
\hline Oregon & 0 & 0 & 0 & 0 & 0 & 0 & 0 & 0 & 0 & 0 \\
\hline Pennsylvania & 6 & 0.062 & 0.062 & 0 & 0 & 6.062 & 0.247 & 0.247 & 0 & 0 \\
\hline Rhode Island & 7 & 0 & 0 & 0 & 0 & 7 & 0 & 0 & 0 & 0 \\
\hline South Carolina & 6 & 1.139 & 0.155 & 0.414 & 0.57 & 7.139 & 0.724 & 0.361 & 0.499 & 0.585 \\
\hline South Dakota & 4 & 1.476 & 0 & 1.218 & 0.258 & 5.476 & 1.179 & 0 & 0.921 & 0.959 \\
\hline Tennessee & 7 & 2.507 & 2.471 & 0.036 & 0 & 9.507 & 0.265 & 0.31 & 0.204 & 0 \\
\hline Texas & 6.25 & 1.402 & 0.223 & 1.064 & 0.115 & 7.652 & 0.722 & 0.254 & 0.726 & 0.294 \\
\hline Utah & 4.7 & 1.664 & 1.139 & 0.235 & 0.291 & 6.364 & 0.486 & 0.499 & 0.427 & 0.403 \\
\hline Vermont & 6 & 0.048 & 0 & 0.048 & 0 & 6.048 & 0.209 & 0 & 0.209 & 0 \\
\hline Virginia & 4 & 1 & 0.862 & 0.138 & 0 & 5 & 0 & 0.345 & 0.345 & 0 \\
\hline Washington & 6.5 & 1.729 & 0.456 & 1.17 & 0.103 & 8.229 & 0.607 & 0.724 & 1.001 & 0.448 \\
\hline West Virginia & 6 & 0.002 & 0 & 0.002 & 0 & 6.002 & 0.048 & 0 & 0.048 & 0 \\
\hline Wisconsin & 5 & 0.444 & 0.427 & 0 & 0.017 & 5.444 & 0.162 & 0.176 & 0 & 0.068 \\
\hline Wyoming & 4 & 1.277 & 1.277 & 0 & 0 & 5.277 & 0.721 & 0.721 & 0 & 0 \\
\hline US & 5.374 & 1.284 & 0.811 & 0.406 & 0.067 & 6.659 & 1.438 & 1.091 & 0.928 & 0.3 \\
\hline
\end{tabular}

The first six numerical columns present the weighted average of the state, total local (county + town + district), county, town, district, and total combined tax rates. The final four 
Table 9: Tax Rates and SDs for December 2010

State State Rate Total Local County Town District Total sd(Total Local)

\begin{tabular}{|c|c|c|c|c|c|c|c|c|c|c|}
\hline & & & & & & & & & & \\
\hline Alabama & 4 & 3.942 & 1.602 & 2.14 & 0.201 & 7.942 & 1.559 & 0.99 & 1.706 & 0.418 \\
\hline Alaska & 0 & 1.156 & 0.56 & 0.596 & 0 & 1.156 & 2.274 & 1.549 & 1.685 & 0 \\
\hline Arizona & 6.6 & 2.301 & 0.696 & 1.605 & 0 & 8.901 & 0.886 & 0.193 & 0.86 & 0 \\
\hline Arkansas & 6 & 2.085 & 1.203 & 0.882 & 0 & 8.085 & 0.945 & 0.532 & 0.837 & 0 \\
\hline California & 8.25 & 0.856 & 0.806 & 0.05 & 0 & 9.106 & 0.539 & 0.539 & 0.17 & 0 \\
\hline Colorado & 2.9 & 3.971 & 0.71 & 2.465 & 0.796 & 6.871 & 1.447 & 0.616 & 1.447 & 0.56 \\
\hline Connecticut & 6 & 0 & 0 & 0 & 0 & 6 & 0 & 0 & 0 & 0 \\
\hline Delaware & 0 & 0 & 0 & 0 & 0 & 0 & 0 & 0 & 0 & 0 \\
\hline District of Columbia & 6 & 0 & 0 & 0 & 0 & 6 & 0 & 0 & 0 & 0 \\
\hline Florida & 6 & 0.685 & 0.685 & 0 & 0 & 6.685 & 0.439 & 0.439 & 0 & 0 \\
\hline Georgia & 4 & 2.834 & 2.791 & 0.044 & 0 & 6.834 & 0.478 & 0.41 & 0.206 & 0 \\
\hline Hawaii & 4 & 0.35 & 0.35 & 0 & 0 & 4.35 & 0.267 & 0.267 & 0 & 0 \\
\hline Idaho & 6 & 0.02 & 0.013 & 0.007 & 0 & 6.02 & 0.12 & 0.08 & 0.091 & 0 \\
\hline Illinois & 6.25 & 1.977 & 0.642 & 0.719 & 0.617 & 8.227 & 1.244 & 0.582 & 0.583 & 0.446 \\
\hline Indiana & 7 & 0 & 0 & 0 & 0 & 7 & 0 & 0 & 0 & 0 \\
\hline Iowa & 6 & 0.794 & 0.788 & 0.006 & 0 & 6.794 & 0.401 & 0.405 & 0.076 & 0 \\
\hline Kansas & 6.3 & 1.83 & 1.04 & 0.772 & 0.018 & 8.13 & 0.725 & 0.362 & 0.663 & 0.077 \\
\hline Kentucky & 6 & 0 & 0 & 0 & 0 & 6 & 0 & 0 & 0 & 0 \\
\hline Louisiana & 4 & 4.655 & 2.244 & 1.75 & 0.661 & 8.655 & 0.649 & 2.131 & 2.304 & 1.352 \\
\hline Maine & 5 & 0 & 0 & 0 & 0 & 5 & 0 & 0 & 0 & 0 \\
\hline Maryland & 6 & 0 & 0 & 0 & 0 & 6 & 0 & 0 & 0 & 0 \\
\hline Massachusetts & 6.25 & 0 & 0 & 0 & 0 & 6.25 & 0 & 0 & 0 & 0 \\
\hline Michigan & 6 & 0 & 0 & 0 & 0 & 6 & 0 & 0 & 0 & 0 \\
\hline Minnesota & 6.875 & 0.278 & 0.034 & 0.121 & 0.124 & 7.153 & 0.296 & 0.069 & 0.233 & 0.126 \\
\hline Mississippi & 7 & 0.003 & 0 & 0.003 & 0 & 7.003 & 0.027 & 0 & 0.027 & 0 \\
\hline Missouri & 4.225 & 3.193 & 1.295 & 1.513 & 0.385 & 7.418 & 0.85 & 0.472 & 1.076 & 0.538 \\
\hline Montana & 0 & 0 & 0 & 0 & 0 & 0 & 0 & 0 & 0 & 0 \\
\hline Nebraska & 5.5 & 1.072 & 0.002 & 1.07 & 0 & 6.572 & 0.644 & 0.033 & 0.647 & 0 \\
\hline Nevada & 4.6 & 3.328 & 3.289 & 0 & 0.039 & 7.928 & 0.358 & 0.396 & 0 & 0.1 \\
\hline New Hampshire & 0 & 0 & 0 & 0 & 0 & 0 & 0 & 0 & 0 & 0 \\
\hline New Jersey & 7 & 0 & 0 & 0 & 0 & 7 & 0 & 0 & 0 & 0 \\
\hline New Mexico & 5.125 & 2.136 & 0.263 & 1.808 & 0.064 & 7.261 & 0.957 & 0.469 & 1.193 & 0.19 \\
\hline New York & 4 & 4.477 & 2.228 & 1.997 & 0.252 & 8.477 & 0.533 & 2.213 & 2.435 & 0.194 \\
\hline North Carolina & 5.75 & 2.093 & 2.045 & 0 & 0.048 & 7.843 & 0.165 & 0.097 & 0 & 0.149 \\
\hline North Dakota & 5 & 1.161 & 0.024 & 1.137 & 0 & 6.161 & 0.872 & 0.111 & 0.863 & 0 \\
\hline Ohio & 5.5 & 1.284 & 1.269 & 0 & 0.015 & 6.784 & 0.431 & 0.441 & 0 & 0.119 \\
\hline Oklahoma & 4.5 & 3.43 & 0.745 & 2.685 & 0 & 7.93 & 1.369 & 0.582 & 1.546 & 0 \\
\hline Oregon & 0 & 0 & 0 & 0 & 0 & 0 & 0 & 0 & 0 & 0 \\
\hline Pennsylvania & 6 & 0.337 & 0.337 & 0 & 0 & 6.337 & 0.689 & 0.689 & 0 & 0 \\
\hline Rhode Island & 7 & 0 & 0 & 0 & 0 & 7 & 0 & 0 & 0 & 0 \\
\hline South Carolina & 6 & 1.1 & 0.261 & 0.269 & 0.57 & 7.1 & 0.785 & 0.441 & 0.512 & 0.585 \\
\hline South Dakota & 4 & 1.675 & 0 & 1.54 & 0.135 & 5.675 & 0.946 & 0 & 0.825 & 0.676 \\
\hline Tennessee & 7 & 2.419 & 2.393 & 0.026 & 0 & 9.419 & 0.244 & 0.311 & 0.231 & 0 \\
\hline Texas & 6.25 & 1.594 & 0.13 & 1.036 & 0.427 & 7.844 & 0.663 & 0.222 & 0.679 & 0.442 \\
\hline Utah & 4.7 & 1.965 & 1.071 & 0.324 & 0.569 & 6.665 & 0.291 & 0.476 & 0.473 & 0.292 \\
\hline Vermont & 6 & 0.157 & 0 & 0.157 & 0 & 6.157 & 0.347 & 0 & 0.347 & 0 \\
\hline Virginia & 4 & 1 & 0.692 & 0.308 & 0 & 5 & 0 & 0.466 & 0.466 & 0 \\
\hline Washington & 6.5 & 2.218 & 0.274 & 1.724 & 0.22 & 8.718 & 0.599 & 0.551 & 1.094 & 0.525 \\
\hline West Virginia & 6 & 0 & 0 & 0 & 0 & 6 & 0 & 0 & 0 & 0 \\
\hline Wisconsin & 5 & 0.424 & 0.373 & 0 & 0.051 & 5.424 & 0.203 & 0.22 & 0 & 0.104 \\
\hline Wyoming & 4 & 1.238 & 1.238 & 0 & 0 & 5.238 & 0.692 & 0.692 & 0 & 0 \\
\hline US & 5.776 & 1.477 & 0.804 & 0.539 & 0.134 & 7.253 & 1.484 & 1.073 & 1.114 & 0.355 \\
\hline
\end{tabular}

The first six numerical columns present the weighted average of the state, total local (county + town + district), county, town, district, and total combined tax rates. The final four

columns present the weighted standard deviations of these rates within a state. All population weights are from the 2010 ACS. The total tax rate is the sum of the first two columns. 
Table 10: Tax Rates and SDs for December 2009

\begin{tabular}{|c|c|c|c|c|c|c|c|c|c|c|}
\hline State & State Rate & Total Local & County & Town & District & Total & sd(Total Local) & sd(County) & sd(Town) & sd(District) \\
\hline Alabama & 4 & 3.845 & 1.561 & 2.093 & 0.192 & 7.845 & 1.488 & 0.942 & 1.617 & 0.412 \\
\hline Alaska & 0 & 1.157 & 0.561 & 0.596 & 0 & 1.157 & 2.276 & 1.55 & 1.687 & 0 \\
\hline Arizona & 5.6 & 2.312 & 0.696 & 1.615 & 0 & 7.912 & 0.833 & 0.193 & 0.809 & 0 \\
\hline Arkansas & 6 & 2.085 & 1.214 & 0.871 & 0 & 8.085 & 0.947 & 0.536 & 0.835 & 0 \\
\hline California & 8.25 & 0.851 & 0.805 & 0.046 & 0 & 9.101 & 0.54 & 0.539 & 0.163 & 0 \\
\hline Colorado & 2.9 & 3.97 & 0.711 & 2.473 & 0.786 & 6.87 & 1.436 & 0.613 & 1.426 & 0.55 \\
\hline Connecticut & 6 & 0 & 0 & 0 & 0 & 6 & 0 & 0 & 0 & 0 \\
\hline Delaware & 0 & 0 & 0 & 0 & 0 & 0 & 0 & 0 & 0 & 0 \\
\hline District of Columbia & 6 & 0 & 0 & 0 & 0 & 6 & 0 & 0 & 0 & 0 \\
\hline Florida & 6 & 0.694 & 0.694 & 0 & 0 & 6.694 & 0.43 & 0.43 & 0 & 0 \\
\hline Georgia & 4 & 2.814 & 2.77 & 0.044 & 0 & 6.814 & 0.492 & 0.424 & 0.206 & 0 \\
\hline Hawaii & 4 & 0.35 & 0.35 & 0 & 0 & 4.35 & 0.267 & 0.267 & 0 & 0 \\
\hline Idaho & 6 & 0.02 & 0.013 & 0.007 & 0 & 6.02 & 0.12 & 0.08 & 0.091 & 0 \\
\hline Illinois & 6.25 & 2.131 & 0.82 & 0.695 & 0.615 & 8.381 & 1.488 & 0.817 & 0.565 & 0.445 \\
\hline Indiana & 7 & 0 & 0 & 0 & 0 & 7 & 0 & 0 & 0 & 0 \\
\hline Iowa & 6 & 0.791 & 0.791 & 0 & 0 & 6.791 & 0.403 & 0.403 & 0.006 & 0 \\
\hline Kansas & 5.3 & 1.786 & 1.029 & 0.747 & 0.01 & 7.086 & 0.713 & 0.37 & 0.639 & 0.066 \\
\hline Kentucky & 6 & 0 & 0 & 0 & 0 & 6 & 0 & 0 & 0 & 0 \\
\hline Louisiana & 4 & 4.624 & 2.238 & 1.961 & 0.425 & 8.624 & 0.685 & 2.127 & 2.211 & 1.196 \\
\hline Maine & 5 & 0 & 0 & 0 & 0 & 5 & 0 & 0 & 0 & 0 \\
\hline Maryland & 6 & 0 & 0 & 0 & 0 & 6 & 0 & 0 & 0 & 0 \\
\hline Massachusetts & 6.25 & 0 & 0 & 0 & 0 & 6.25 & 0 & 0 & 0 & 0 \\
\hline Michigan & 6 & 0 & 0 & 0 & 0 & 6 & 0 & 0 & 0 & 0 \\
\hline Minnesota & 6.875 & 0.278 & 0.033 & 0.121 & 0.124 & 7.153 & 0.295 & 0.062 & 0.233 & 0.126 \\
\hline Mississippi & 7 & 0.003 & 0 & 0.003 & 0 & 7.003 & 0.027 & 0 & 0.027 & 0 \\
\hline Missouri & 4.225 & 2.963 & 1.252 & 1.427 & 0.284 & 7.188 & 0.82 & 0.438 & 1.062 & 0.369 \\
\hline Montana & 0 & 0 & 0 & 0 & 0 & 0 & 0 & 0 & 0 & 0 \\
\hline Nebraska & 5.5 & 1.066 & 0.002 & 1.063 & 0 & 6.566 & 0.646 & 0.033 & 0.649 & 0 \\
\hline Nevada & 4.6 & 3.328 & 3.289 & 0 & 0.039 & 7.928 & 0.358 & 0.396 & 0 & 0.1 \\
\hline New Hampshire & 0 & 0 & 0 & 0 & 0 & 0 & 0 & 0 & 0 & 0 \\
\hline New Jersey & 7 & 0 & 0 & 0 & 0 & 7 & 0 & 0 & 0 & 0 \\
\hline New Mexico & 5 & 2.119 & 0.267 & 1.79 & 0.062 & 7.119 & 0.926 & 0.472 & 1.18 & 0.184 \\
\hline New York & 4 & 4.478 & 2.23 & 1.996 & 0.252 & 8.478 & 0.53 & 2.215 & 2.435 & 0.194 \\
\hline North Carolina & 5.75 & 2.072 & 2.024 & 0 & 0.048 & 7.822 & 0.159 & 0.074 & 0 & 0.149 \\
\hline North Dakota & 5 & 1.057 & 0.024 & 1.033 & 0 & 6.057 & 0.786 & 0.111 & 0.773 & 0 \\
\hline Ohio & 5.5 & 1.304 & 1.291 & 0 & 0.013 & 6.804 & 0.402 & 0.414 & 0 & 0.104 \\
\hline Oklahoma & 4.5 & 3.39 & 0.728 & 2.662 & 0 & 7.89 & 1.367 & 0.572 & 1.535 & 0 \\
\hline Oregon & 0 & 0 & 0 & 0 & 0 & 0 & 0 & 0 & 0 & 0 \\
\hline Pennsylvania & 6 & 0.337 & 0.337 & 0 & 0 & 6.337 & 0.689 & 0.689 & 0 & 0 \\
\hline Rhode Island & 7 & 0 & 0 & 0 & 0 & 7 & 0 & 0 & 0 & 0 \\
\hline South Carolina & 6 & 1.106 & 0.261 & 0.27 & 0.574 & 7.106 & 0.789 & 0.44 & 0.513 & 0.584 \\
\hline South Dakota & 4 & 1.671 & 0 & 1.535 & 0.135 & 5.671 & 0.948 & 0 & 0.827 & 0.676 \\
\hline Tennessee & 7 & 2.419 & 2.393 & 0.026 & 0 & 9.419 & 0.244 & 0.311 & 0.231 & 0 \\
\hline Texas & 6.25 & 1.591 & 0.13 & 1.04 & 0.421 & 7.841 & 0.67 & 0.222 & 0.674 & 0.442 \\
\hline Utah & 4.7 & 1.967 & 1.075 & 0.324 & 0.569 & 6.667 & 0.287 & 0.479 & 0.473 & 0.292 \\
\hline Vermont & 6 & 0.157 & 0 & 0.157 & 0 & 6.157 & 0.348 & 0 & 0.348 & 0 \\
\hline Virginia & 4 & 1 & 0.692 & 0.308 & 0 & 5 & 0 & 0.466 & 0.466 & 0 \\
\hline Washington & 6.5 & 2.207 & 0.272 & 1.72 & 0.216 & 8.707 & 0.603 & 0.544 & 1.094 & 0.518 \\
\hline West Virginia & 6 & 0 & 0 & 0 & 0 & 6 & 0 & 0 & 0 & 0 \\
\hline Wisconsin & 5 & 0.415 & 0.364 & 0 & 0.051 & 5.415 & 0.21 & 0.225 & 0 & 0.104 \\
\hline Wyoming & 4 & 1.315 & 1.315 & 0 & 0 & 5.315 & 0.718 & 0.718 & 0 & 0 \\
\hline US & 5.745 & 1.475 & 0.81 & 0.537 & 0.128 & 7.22 & 1.483 & 1.075 & 1.107 & 0.336 \\
\hline
\end{tabular}

The first six numerical columns present the weighted average of the state, total local (county + town + district), county, town, district, and total combined tax rates. The final four columns present the weighted standard deviations of these rates within a state. All population weights are from the 2010 ACS. The total tax rate is the sum of the first two columns. 
Table 11: Tax Rates and SDs for December 2008

\begin{tabular}{|c|c|c|c|c|c|c|c|c|c|c|}
\hline State & State Rate & Total Local & County & Town & District & Total & sd(Total Local) & sd(County) & sd(Town) & sd(District) \\
\hline Alabama & 4 & 3.811 & 1.536 & 2.084 & 0.191 & 7.811 & 1.484 & 0.945 & 1.61 & 0.411 \\
\hline Alaska & 0 & 1.157 & 0.561 & 0.596 & 0 & 1.157 & 2.276 & 1.55 & 1.687 & 0 \\
\hline Arizona & 5.6 & 2.309 & 0.689 & 1.62 & 0 & 7.909 & 0.844 & 0.185 & 0.805 & 0 \\
\hline Arkansas & 6 & 2.094 & 1.223 & 0.871 & 0 & 8.094 & 0.958 & 0.526 & 0.842 & 0 \\
\hline California & 7.25 & 0.704 & 0.668 & 0.036 & 0 & 7.954 & 0.395 & 0.393 & 0.139 & 0 \\
\hline Colorado & 2.9 & 3.969 & 0.71 & 2.477 & 0.783 & 6.869 & 1.433 & 0.612 & 1.425 & 0.55 \\
\hline Connecticut & 6 & 0 & 0 & 0 & 0 & 6 & 0 & 0 & 0 & 0 \\
\hline Delaware & 0 & 0 & 0 & 0 & 0 & 0 & 0 & 0 & 0 & 0 \\
\hline District of Columbia & 5.75 & 0 & 0 & 0 & 0 & 5.75 & 0 & 0 & 0 & 0 \\
\hline Florida & 6 & 0.685 & 0.685 & 0 & 0 & 6.685 & 0.431 & 0.431 & 0 & 0 \\
\hline Georgia & 4 & 2.803 & 2.759 & 0.044 & 0 & 6.803 & 0.503 & 0.435 & 0.206 & 0 \\
\hline Hawaii & 4 & 0.35 & 0.35 & 0 & 0 & 4.35 & 0.267 & 0.267 & 0 & 0 \\
\hline Idaho & 6 & 0.02 & 0.013 & 0.007 & 0 & 6.02 & 0.12 & 0.08 & 0.091 & 0 \\
\hline Illinois & 6.25 & 2.103 & 0.809 & 0.68 & 0.614 & 8.353 & 1.504 & 0.826 & 0.569 & 0.445 \\
\hline Indiana & 7 & 0 & 0 & 0 & 0 & 7 & 0 & 0 & 0 & 0 \\
\hline Iowa & 6 & 0.687 & 0.687 & 0 & 0 & 6.687 & 0.458 & 0.458 & 0.006 & 0 \\
\hline Kansas & 5.3 & 1.676 & 0.986 & 0.682 & 0.008 & 6.976 & 0.653 & 0.354 & 0.583 & 0.063 \\
\hline Kentucky & 6 & 0 & 0 & 0 & 0 & 6 & 0 & 0 & 0 & 0 \\
\hline Louisiana & 4 & 4.605 & 2.278 & 1.892 & 0.435 & 8.605 & 0.684 & 2.156 & 2.225 & 1.211 \\
\hline Maine & 5 & 0 & 0 & 0 & 0 & 5 & 0 & 0 & 0 & 0 \\
\hline Maryland & 6 & 0 & 0 & 0 & 0 & 6 & 0 & 0 & 0 & 0 \\
\hline Massachusetts & 5 & 0 & 0 & 0 & 0 & 5 & 0 & 0 & 0 & 0 \\
\hline Michigan & 6 & 0 & 0 & 0 & 0 & 6 & 0 & 0 & 0 & 0 \\
\hline Minnesota & 6.5 & 0.276 & 0.033 & 0.12 & 0.124 & 6.776 & 0.295 & 0.062 & 0.233 & 0.126 \\
\hline Mississippi & 7 & 0.003 & 0 & 0.003 & 0 & 7.003 & 0.027 & 0 & 0.027 & 0 \\
\hline Missouri & 4.225 & 2.848 & 1.196 & 1.403 & 0.249 & 7.073 & 0.839 & 0.436 & 1.071 & 0.342 \\
\hline Montana & 0 & 0 & 0 & 0 & 0 & 0 & 0 & 0 & 0 & 0 \\
\hline Nebraska & 5.5 & 1.06 & 0.002 & 1.058 & 0 & 6.56 & 0.65 & 0.033 & 0.653 & 0 \\
\hline Nevada & 4.25 & 3.328 & 3.289 & 0 & 0.039 & 7.578 & 0.358 & 0.396 & 0 & 0.1 \\
\hline New Hampshire & 0 & 0 & 0 & 0 & 0 & 0 & 0 & 0 & 0 & 0 \\
\hline New Jersey & 7 & 0 & 0 & 0 & 0 & 7 & 0 & 0 & 0 & 0 \\
\hline New Mexico & 5 & 1.963 & 0.624 & 1.321 & 0.018 & 6.963 & 0.919 & 0.338 & 1.078 & 0.081 \\
\hline New York & 4 & 4.265 & 2.228 & 1.785 & 0.252 & 8.265 & 0.394 & 2.213 & 2.172 & 0.194 \\
\hline North Carolina & 4.5 & 2.322 & 2.274 & 0 & 0.048 & 6.822 & 0.159 & 0.074 & 0 & 0.149 \\
\hline North Dakota & 5 & 0.973 & 0.024 & 0.949 & 0 & 5.973 & 0.757 & 0.111 & 0.74 & 0 \\
\hline Ohio & 5.5 & 1.263 & 1.25 & 0 & 0.013 & 6.763 & 0.439 & 0.449 & 0 & 0.104 \\
\hline Oklahoma & 4.5 & 3.344 & 0.701 & 2.644 & 0 & 7.844 & 1.36 & 0.582 & 1.53 & 0 \\
\hline Oregon & 0 & 0 & 0 & 0 & 0 & 0 & 0 & 0 & 0 & 0 \\
\hline Pennsylvania & 6 & 0.217 & 0.217 & 0 & 0 & 6.217 & 0.417 & 0.417 & 0 & 0 \\
\hline Rhode Island & 7 & 0 & 0 & 0 & 0 & 7 & 0 & 0 & 0 & 0 \\
\hline South Carolina & 6 & 0.937 & 0.341 & 0.261 & 0.336 & 6.937 & 0.646 & 0.514 & 0.5 & 0.45 \\
\hline South Dakota & 4 & 1.649 & 0 & 1.512 & 0.137 & 5.649 & 0.943 & 0 & 0.818 & 0.68 \\
\hline Tennessee & 7 & 2.403 & 2.392 & 0.01 & 0 & 9.403 & 0.236 & 0.232 & 0.066 & 0 \\
\hline Texas & 6.25 & 1.58 & 0.13 & 1.033 & 0.417 & 7.83 & 0.682 & 0.222 & 0.681 & 0.438 \\
\hline Utah & 4.65 & 1.921 & 1.034 & 0.322 & 0.565 & 6.571 & 0.287 & 0.51 & 0.473 & 0.298 \\
\hline Vermont & 6 & 0.13 & 0 & 0.13 & 0 & 6.13 & 0.318 & 0 & 0.318 & 0 \\
\hline Virginia & 4 & 1 & 0.691 & 0.309 & 0 & 5 & 0 & 0.466 & 0.466 & 0 \\
\hline Washington & 6.5 & 1.988 & 0.286 & 1.512 & 0.19 & 8.488 & 0.423 & 0.557 & 0.936 & 0.46 \\
\hline West Virginia & 6 & 0 & 0 & 0 & 0 & 6 & 0 & 0 & 0 & 0 \\
\hline Wisconsin & 5 & 0.412 & 0.361 & 0 & 0.051 & 5.412 & 0.213 & 0.226 & 0 & 0.104 \\
\hline Wyoming & 4 & 1.344 & 1.344 & 0 & 0 & 5.344 & 0.633 & 0.633 & 0 & 0 \\
\hline US & 5.549 & 1.427 & 0.794 & 0.511 & 0.122 & 6.976 & 1.454 & 1.074 & 1.047 & 0.326 \\
\hline
\end{tabular}

The first six numerical columns present the weighted average of the state, total local (county + town + district), county, town, district, and total combined tax rates. The final four columns present the weighted standard deviations of these rates within a state. All population weights are from the 2010 ACS. The total tax rate is the sum of the first two columns. 
Table 12: Tax Rates and SDs for December 2007

\begin{tabular}{|c|c|c|c|c|c|c|c|c|c|c|}
\hline State & State Rate & Total Local & County & Town & District & Total & sd(Total Local) & sd(County) & sd(Town) & sd(District) \\
\hline Alabama & 4 & 3.751 & 1.536 & 2.025 & 0.191 & 7.751 & 1.43 & 0.945 & 1.567 & 0.411 \\
\hline Alaska & 0 & 1.07 & 0.481 & 0.589 & 0 & 1.07 & 2.141 & 1.419 & 1.657 & 0 \\
\hline Arizona & 5.6 & 2.314 & 0.69 & 1.624 & 0 & 7.914 & 0.81 & 0.187 & 0.775 & 0 \\
\hline Arkansas & 6 & 2.085 & 1.216 & 0.864 & 0.005 & 8.085 & 0.932 & 0.509 & 0.83 & 0.051 \\
\hline California & 7.25 & 0.696 & 0.668 & 0.028 & 0 & 7.946 & 0.392 & 0.393 & 0.112 & 0 \\
\hline Colorado & 2.9 & 3.949 & 0.69 & 2.479 & 0.78 & 6.849 & 1.465 & 0.61 & 1.43 & 0.549 \\
\hline Connecticut & 6 & 0 & 0 & 0 & 0 & 6 & 0 & 0 & 0 & 0 \\
\hline Delaware & 0 & 0 & 0 & 0 & 0 & 0 & 0 & 0 & 0 & 0 \\
\hline District of Columbia & 5.75 & 0 & 0 & 0 & 0 & 5.75 & 0 & 0 & 0 & 0 \\
\hline Florida & 6 & 0.689 & 0.689 & 0 & 0 & 6.689 & 0.427 & 0.427 & 0 & 0 \\
\hline Georgia & 4 & 2.815 & 2.771 & 0.044 & 0 & 6.815 & 0.496 & 0.428 & 0.206 & 0 \\
\hline Hawaii & 4 & 0.35 & 0.35 & 0 & 0 & 4.35 & 0.267 & 0.267 & 0 & 0 \\
\hline Idaho & 6 & 0.017 & 0.013 & 0.005 & 0 & 6.017 & 0.115 & 0.08 & 0.083 & 0 \\
\hline Illinois & 6.25 & 1.438 & 0.397 & 0.653 & 0.388 & 7.688 & 1.032 & 0.366 & 0.57 & 0.339 \\
\hline Indiana & 6 & 0 & 0 & 0 & 0 & 6 & 0 & 0 & 0 & 0 \\
\hline Iowa & 5 & 1.666 & 0.676 & 0 & 0.991 & 6.666 & 0.468 & 0.462 & 0.007 & 0.068 \\
\hline Kansas & 5.3 & 1.848 & 1.165 & 0.675 & 0.008 & 7.148 & 0.576 & 0.527 & 0.58 & 0.063 \\
\hline Kentucky & 6 & 0 & 0 & 0 & 0 & 6 & 0 & 0 & 0 & 0 \\
\hline Louisiana & 4 & 4.594 & 2.309 & 1.854 & 0.431 & 8.594 & 0.698 & 2.149 & 2.212 & 1.214 \\
\hline Maine & 5 & 0 & 0 & 0 & 0 & 5 & 0 & 0 & 0 & 0 \\
\hline Maryland & 5 & 0 & 0 & 0 & 0 & 5 & 0 & 0 & 0 & 0 \\
\hline Massachusetts & 5 & 0 & 0 & 0 & 0 & 5 & 0 & 0 & 0 & 0 \\
\hline Michigan & 6 & 0 & 0 & 0 & 0 & 6 & 0 & 0 & 0 & 0 \\
\hline Minnesota & 6.5 & 0.152 & 0.034 & 0.118 & 0 & 6.652 & 0.248 & 0.069 & 0.232 & 0 \\
\hline Mississippi & 7 & 0.003 & 0 & 0.003 & 0 & 7.003 & 0.027 & 0 & 0.027 & 0 \\
\hline Missouri & 4.225 & 2.757 & 1.179 & 1.332 & 0.246 & 6.982 & 0.863 & 0.44 & 1.024 & 0.337 \\
\hline Montana & 0 & 0 & 0 & 0 & 0 & 0 & 0 & 0 & 0 & 0 \\
\hline Nebraska & 5.5 & 1.054 & 0.002 & 1.052 & 0 & 6.554 & 0.652 & 0.033 & 0.655 & 0 \\
\hline Nevada & 4.25 & 3.323 & 3.284 & 0 & 0.039 & 7.573 & 0.374 & 0.41 & 0 & 0.1 \\
\hline New Hampshire & 0 & 0 & 0 & 0 & 0 & 0 & 0 & 0 & 0 & 0 \\
\hline New Jersey & 7 & 0 & 0 & 0 & 0 & 7 & 0 & 0 & 0 & 0 \\
\hline New Mexico & 5 & 2.065 & 0.703 & 1.361 & 0 & 7.065 & 0.994 & 0.319 & 1.026 & 0 \\
\hline New York & 4 & 4.264 & 2.228 & 1.784 & 0.252 & 8.264 & 0.395 & 2.213 & 2.171 & 0.194 \\
\hline North Carolina & 4.25 & 2.548 & 2.5 & 0 & 0.048 & 6.798 & 0.149 & 0 & 0 & 0.149 \\
\hline North Dakota & 5 & 0.964 & 0.024 & 0.94 & 0 & 5.964 & 0.751 & 0.111 & 0.733 & 0 \\
\hline Ohio & 5.5 & 1.245 & 1.06 & 0 & 0.185 & 6.745 & 0.444 & 0.3 & 0 & 0.32 \\
\hline Oklahoma & 4.5 & 3.293 & 0.68 & 2.613 & 0 & 7.793 & 1.358 & 0.592 & 1.518 & 0 \\
\hline Oregon & 0 & 0 & 0 & 0 & 0 & 0 & 0 & 0 & 0 & 0 \\
\hline Pennsylvania & 6 & 0.217 & 0.217 & 0 & 0 & 6.217 & 0.417 & 0.417 & 0 & 0 \\
\hline Rhode Island & 7 & 0 & 0 & 0 & 0 & 7 & 0 & 0 & 0 & 0 \\
\hline South Carolina & 6 & 0.938 & 0.341 & 0.27 & 0.328 & 6.938 & 0.646 & 0.513 & 0.52 & 0.447 \\
\hline South Dakota & 4 & 1.641 & 0 & 1.504 & 0.137 & 5.641 & 0.946 & 0 & 0.821 & 0.681 \\
\hline Tennessee & 7 & 2.393 & 2.386 & 0.007 & 0 & 9.393 & 0.231 & 0.228 & 0.057 & 0 \\
\hline Texas & 6.25 & 1.564 & 0.13 & 1.027 & 0.407 & 7.814 & 0.701 & 0.222 & 0.685 & 0.441 \\
\hline Utah & 4.75 & 1.831 & 1.134 & 0.322 & 0.374 & 6.581 & 0.283 & 0.521 & 0.474 & 0.192 \\
\hline Vermont & 6 & 0.076 & 0 & 0.076 & 0 & 6.076 & 0.264 & 0 & 0.264 & 0 \\
\hline Virginia & 4 & 1 & 0.691 & 0.309 & 0 & 5 & 0 & 0.466 & 0.466 & 0 \\
\hline Washington & 6.5 & 1.946 & 0.381 & 1.201 & 0.364 & 8.446 & 0.414 & 0.643 & 0.909 & 0.528 \\
\hline West Virginia & 6 & 0 & 0 & 0 & 0 & 6 & 0 & 0 & 0 & 0 \\
\hline Wisconsin & 5 & 0.412 & 0.361 & 0 & 0.051 & 5.412 & 0.213 & 0.226 & 0 & 0.104 \\
\hline Wyoming & 4 & 1.387 & 1.387 & 0 & 0 & 5.387 & 0.575 & 0.575 & 0 & 0 \\
\hline US & 5.493 & 1.407 & 0.781 & 0.498 & 0.128 & 6.9 & 1.43 & 1.074 & 1.034 & 0.327 \\
\hline
\end{tabular}

The first six numerical columns present the weighted average of the state, total local (county + town + district), county, town, district, and total combined tax rates. The final four columns present the weighted standard deviations of these rates within a state. All population weights are from the 2010 ACS. The total tax rate is the sum of the first two columns. 
Table 13: Tax Rates and SDs for December 2006

\begin{tabular}{|c|c|c|c|c|c|c|c|c|c|c|}
\hline State & State Rate & Total Local & County & Town & District & Total & sd(Total Local) & sd(County) & sd(Town) & sd(District) \\
\hline Alabama & 4 & 3.697 & 1.537 & 1.994 & 0.166 & 7.697 & 1.433 & 0.929 & 1.552 & 0.392 \\
\hline Alaska & 0 & 1.067 & 0.481 & 0.586 & 0 & 1.067 & 2.137 & 1.419 & 1.652 & 0 \\
\hline Arizona & 5.6 & 2.256 & 0.696 & 1.56 & 0 & 7.856 & 0.792 & 0.225 & 0.744 & 0 \\
\hline Arkansas & 6 & 2.035 & 1.178 & 0.852 & 0.005 & 8.035 & 0.884 & 0.437 & 0.832 & 0.051 \\
\hline California & 7.25 & 0.68 & 0.66 & 0.02 & 0 & 7.93 & 0.395 & 0.402 & 0.097 & 0 \\
\hline Colorado & 2.9 & 3.901 & 0.683 & 2.433 & 0.785 & 6.801 & 1.475 & 0.61 & 1.453 & 0.552 \\
\hline Connecticut & 6 & 0 & 0 & 0 & 0 & 6 & 0 & 0 & 0 & 0 \\
\hline Delaware & 0 & 0 & 0 & 0 & 0 & 0 & 0 & 0 & 0 & 0 \\
\hline District of Columbia & 5.75 & 0 & 0 & 0 & 0 & 5.75 & 0 & 0 & 0 & 0 \\
\hline Florida & 6 & 0.685 & 0.685 & 0 & 0 & 6.685 & 0.43 & 0.43 & 0 & 0 \\
\hline Georgia & 4 & 2.772 & 2.727 & 0.044 & 0 & 6.772 & 0.517 & 0.447 & 0.207 & 0 \\
\hline Hawaii & 4 & 0 & 0 & 0 & 0 & 4 & 0 & 0 & 0 & 0 \\
\hline Idaho & 6 & 0.018 & 0.013 & 0.005 & 0 & 6.018 & 0.134 & 0.08 & 0.108 & 0 \\
\hline Illinois & 6.25 & 1.404 & 0.392 & 0.627 & 0.385 & 7.654 & 1.038 & 0.361 & 0.575 & 0.336 \\
\hline Indiana & 6 & 0 & 0 & 0 & 0 & 6 & 0 & 0 & 0 & 0 \\
\hline Iowa & 5 & 1.537 & 0.659 & 0 & 0.878 & 6.537 & 0.686 & 0.468 & 0.006 & 0.322 \\
\hline Kansas & 5.3 & 1.82 & 1.155 & 0.66 & 0.005 & 7.12 & 0.569 & 0.527 & 0.574 & 0.026 \\
\hline Kentucky & 6 & 0 & 0 & 0 & 0 & 6 & 0 & 0 & 0 & 0 \\
\hline Louisiana & 4 & 4.547 & 2.379 & 1.758 & 0.409 & 8.547 & 0.677 & 2.168 & 2.226 & 1.218 \\
\hline Maine & 5 & 0 & 0 & 0 & 0 & 5 & 0 & 0 & 0 & 0 \\
\hline Maryland & 5 & 0 & 0 & 0 & 0 & 5 & 0 & 0 & 0 & 0 \\
\hline Massachusetts & 5 & 0 & 0 & 0 & 0 & 5 & 0 & 0 & 0 & 0 \\
\hline Michigan & 6 & 0 & 0 & 0 & 0 & 6 & 0 & 0 & 0 & 0 \\
\hline Minnesota & 6.5 & 0.113 & 0.001 & 0.112 & 0 & 6.613 & 0.23 & 0.031 & 0.228 & 0 \\
\hline Mississippi & 7 & 0.003 & 0 & 0.003 & 0 & 7.003 & 0.027 & 0 & 0.027 & 0 \\
\hline Missouri & 4.225 & 2.593 & 1.153 & 1.078 & 0.362 & 6.818 & 0.886 & 0.446 & 0.856 & 0.323 \\
\hline Montana & 0 & 0 & 0 & 0 & 0 & 0 & 0 & 0 & 0 & 0 \\
\hline Nebraska & 5.5 & 1.045 & 0.002 & 1.042 & 0 & 6.545 & 0.662 & 0.034 & 0.665 & 0 \\
\hline Nevada & 4.25 & 3.322 & 3.283 & 0 & 0.039 & 7.572 & 0.375 & 0.411 & 0 & 0.1 \\
\hline New Hampshire & 0 & 0 & 0 & 0 & 0 & 0 & 0 & 0 & 0 & 0 \\
\hline New Jersey & 7 & 0.001 & 0 & 0.001 & 0 & 7.001 & 0.043 & 0 & 0.043 & 0 \\
\hline New Mexico & 5 & 1.871 & 0.68 & 1.191 & 0 & 6.871 & 0.633 & 0.305 & 0.743 & 0 \\
\hline New York & 4 & 4.256 & 2.217 & 1.787 & 0.252 & 8.256 & 0.405 & 2.208 & 2.172 & 0.194 \\
\hline North Carolina & 4.25 & 2.548 & 2.5 & 0 & 0.048 & 6.798 & 0.149 & 0 & 0 & 0.149 \\
\hline North Dakota & 5 & 0.932 & 0.024 & 0.909 & 0 & 5.932 & 0.729 & 0.111 & 0.713 & 0 \\
\hline Ohio & 5.5 & 1.204 & 1.019 & 0 & 0.185 & 6.704 & 0.391 & 0.295 & 0 & 0.32 \\
\hline Oklahoma & 4.5 & 3.252 & 0.665 & 2.588 & 0 & 7.752 & 1.364 & 0.615 & 1.511 & 0 \\
\hline Oregon & 0 & 0 & 0 & 0 & 0 & 0 & 0 & 0 & 0 & 0 \\
\hline Pennsylvania & 6 & 0.217 & 0.217 & 0 & 0 & 6.217 & 0.417 & 0.417 & 0 & 0 \\
\hline Rhode Island & 7 & 0 & 0 & 0 & 0 & 7 & 0 & 0 & 0 & 0 \\
\hline South Carolina & 5 & 0.801 & 0.248 & 0.257 & 0.295 & 5.801 & 0.68 & 0.434 & 0.493 & 0.433 \\
\hline South Dakota & 4 & 1.635 & 0 & 1.498 & 0.137 & 5.635 & 0.947 & 0 & 0.821 & 0.681 \\
\hline Tennessee & 7 & 2.381 & 2.362 & 0.019 & 0 & 9.381 & 0.241 & 0.26 & 0.161 & 0 \\
\hline Texas & 6.25 & 1.557 & 0.13 & 1.026 & 0.401 & 7.807 & 0.703 & 0.221 & 0.686 & 0.441 \\
\hline Utah & 4.75 & 1.69 & 0.994 & 0.322 & 0.374 & 6.44 & 0.231 & 0.497 & 0.473 & 0.192 \\
\hline Vermont & 6 & 0.076 & 0 & 0.076 & 0 & 6.076 & 0.264 & 0 & 0.264 & 0 \\
\hline Virginia & 4 & 1 & 0.691 & 0.309 & 0 & 5 & 0 & 0.466 & 0.466 & 0 \\
\hline Washington & 6.5 & 1.91 & 0.362 & 1.174 & 0.374 & 8.41 & 0.411 & 0.625 & 0.886 & 0.556 \\
\hline West Virginia & 6 & 0 & 0 & 0 & 0 & 6 & 0 & 0 & 0 & 0 \\
\hline Wisconsin & 5 & 0.398 & 0.347 & 0 & 0.051 & 5.398 & 0.223 & 0.233 & 0 & 0.104 \\
\hline Wyoming & 4 & 1.321 & 1.321 & 0 & 0 & 5.321 & 0.708 & 0.708 & 0 & 0 \\
\hline US & 5.478 & 1.382 & 0.769 & 0.485 & 0.128 & 6.861 & 1.422 & 1.072 & 1.019 & 0.326 \\
\hline
\end{tabular}

The first six numerical columns present the weighted average of the state, total local (county + town + district), county, town, district, and total combined tax rates. The final four columns present the weighted standard deviations of these rates within a state. All population weights are from the 2010 ACS. The total tax rate is the sum of the first two columns. 
Table 14: Tax Rates and SDs for December 2005

\begin{tabular}{|c|c|c|c|c|c|c|c|c|c|c|}
\hline State & State Rate & Total Local & County & Town & District & Total & sd(Total Local) & sd(County) & sd(Town) & sd(District) \\
\hline Alabama & 4 & 3.678 & 1.537 & 1.975 & 0.166 & 7.678 & 1.42 & 0.929 & 1.536 & 0.392 \\
\hline Alaska & 0 & 1.066 & 0.472 & 0.594 & 0 & 1.066 & 2.133 & 1.401 & 1.662 & 0 \\
\hline Arizona & 5.6 & 2.146 & 0.614 & 1.532 & 0 & 7.746 & 0.844 & 0.343 & 0.743 & 0 \\
\hline Arkansas & 6 & 2.026 & 1.181 & 0.84 & 0.005 & 8.026 & 0.889 & 0.482 & 0.813 & 0.051 \\
\hline California & 7.25 & 0.673 & 0.66 & 0.013 & 0 & 7.923 & 0.399 & 0.402 & 0.071 & 0 \\
\hline Colorado & 2.9 & 3.871 & 0.691 & 2.395 & 0.784 & 6.771 & 1.456 & 0.607 & 1.445 & 0.551 \\
\hline Connecticut & 6 & 0 & 0 & 0 & 0 & 6 & 0 & 0 & 0 & 0 \\
\hline Delaware & 0 & 0 & 0 & 0 & 0 & 0 & 0 & 0 & 0 & 0 \\
\hline District of Columbia & 5.75 & 0 & 0 & 0 & 0 & 5.75 & 0 & 0 & 0 & 0 \\
\hline Florida & 6 & 0.684 & 0.684 & 0 & 0 & 6.684 & 0.43 & 0.43 & 0 & 0 \\
\hline Georgia & 4 & 2.679 & 2.634 & 0.044 & 0 & 6.679 & 0.677 & 0.619 & 0.207 & 0 \\
\hline Hawaii & 4 & 0 & 0 & 0 & 0 & 4 & 0 & 0 & 0 & 0 \\
\hline Idaho & 5 & 0.062 & 0.056 & 0.005 & 0 & 5.062 & 0.192 & 0.161 & 0.108 & 0 \\
\hline Illinois & 6.25 & 1.369 & 0.386 & 0.599 & 0.385 & 7.619 & 1.039 & 0.362 & 0.572 & 0.336 \\
\hline Indiana & 6 & 0 & 0 & 0 & 0 & 6 & 0 & 0 & 0 & 0 \\
\hline Iowa & 5 & 1.505 & 0.648 & 0 & 0.857 & 6.505 & 0.681 & 0.472 & 0.006 & 0.345 \\
\hline Kansas & 5.3 & 1.787 & 1.137 & 0.645 & 0.005 & 7.087 & 0.574 & 0.518 & 0.56 & 0.026 \\
\hline Kentucky & 6 & 0 & 0 & 0 & 0 & 6 & 0 & 0 & 0 & 0 \\
\hline Louisiana & 4 & 4.513 & 2.36 & 1.747 & 0.406 & 8.513 & 0.684 & 2.157 & 2.212 & 1.2 \\
\hline Maine & 5 & 0 & 0 & 0 & 0 & 5 & 0 & 0 & 0 & 0 \\
\hline Maryland & 5 & 0 & 0 & 0 & 0 & 5 & 0 & 0 & 0 & 0 \\
\hline Massachusetts & 5 & 0 & 0 & 0 & 0 & 5 & 0 & 0 & 0 & 0 \\
\hline Michigan & 6 & 0 & 0 & 0 & 0 & 6 & 0 & 0 & 0 & 0 \\
\hline Minnesota & 6.5 & 0.106 & 0.001 & 0.105 & 0 & 6.606 & 0.226 & 0.031 & 0.224 & 0 \\
\hline Mississippi & 7 & 0.003 & 0 & 0.003 & 0 & 7.003 & 0.027 & 0 & 0.027 & 0 \\
\hline Missouri & 4.225 & 2.489 & 1.087 & 1.067 & 0.335 & 6.714 & 0.867 & 0.461 & 0.857 & 0.321 \\
\hline Montana & 0 & 0 & 0 & 0 & 0 & 0 & 0 & 0 & 0 & 0 \\
\hline Nebraska & 5.5 & 1.025 & 0.002 & 1.023 & 0 & 6.525 & 0.665 & 0.034 & 0.668 & 0 \\
\hline Nevada & 4.25 & 3.32 & 3.281 & 0 & 0.039 & 7.57 & 0.379 & 0.414 & 0 & 0.1 \\
\hline New Hampshire & 0 & 0 & 0 & 0 & 0 & 0 & 0 & 0 & 0 & 0 \\
\hline New Jersey & 6 & 0.003 & 0 & 0.003 & 0 & 6.003 & 0.076 & 0 & 0.076 & 0 \\
\hline New Mexico & 5 & 1.802 & 0.617 & 1.185 & 0 & 6.802 & 0.629 & 0.326 & 0.738 & 0 \\
\hline New York & 4 & 4.234 & 2.194 & 1.788 & 0.252 & 8.234 & 0.419 & 2.184 & 2.17 & 0.194 \\
\hline North Carolina & 4.5 & 2.548 & 2.5 & 0 & 0.048 & 7.048 & 0.149 & 0 & 0 & 0.149 \\
\hline North Dakota & 5 & 0.987 & 0.007 & 0.98 & 0 & 5.987 & 0.743 & 0.064 & 0.744 & 0 \\
\hline Ohio & 5.5 & 1.199 & 1.015 & 0 & 0.184 & 6.699 & 0.391 & 0.292 & 0 & 0.32 \\
\hline Oklahoma & 4.5 & 3.235 & 0.636 & 2.599 & 0 & 7.735 & 1.368 & 0.611 & 1.514 & 0 \\
\hline Oregon & 0 & 0 & 0 & 0 & 0 & 0 & 0 & 0 & 0 & 0 \\
\hline Pennsylvania & 6 & 0.217 & 0.217 & 0 & 0 & 6.217 & 0.417 & 0.417 & 0 & 0 \\
\hline Rhode Island & 7 & 0 & 0 & 0 & 0 & 7 & 0 & 0 & 0 & 0 \\
\hline South Carolina & 5 & 0.791 & 0.244 & 0.257 & 0.291 & 5.791 & 0.678 & 0.431 & 0.492 & 0.431 \\
\hline South Dakota & 4 & 1.618 & 0 & 1.481 & 0.137 & 5.618 & 0.947 & 0 & 0.818 & 0.681 \\
\hline Tennessee & 7 & 2.372 & 2.35 & 0.021 & 0 & 9.372 & 0.229 & 0.258 & 0.167 & 0 \\
\hline Texas & 6.25 & 1.551 & 0.13 & 1.026 & 0.395 & 7.801 & 0.706 & 0.221 & 0.683 & 0.434 \\
\hline Utah & 4.75 & 1.684 & 0.994 & 0.316 & 0.374 & 6.434 & 0.234 & 0.497 & 0.468 & 0.192 \\
\hline Vermont & 6 & 0.008 & 0 & 0.008 & 0 & 6.008 & 0.069 & 0 & 0.069 & 0 \\
\hline Virginia & 4 & 1 & 0.691 & 0.309 & 0 & 5 & 0 & 0.466 & 0.466 & 0 \\
\hline Washington & 6.5 & 1.882 & 0.358 & 1.152 & 0.372 & 8.382 & 0.433 & 0.619 & 0.876 & 0.554 \\
\hline West Virginia & 6 & 0 & 0 & 0 & 0 & 6 & 0 & 0 & 0 & 0 \\
\hline Wisconsin & 5 & 0.398 & 0.346 & 0 & 0.052 & 5.398 & 0.224 & 0.233 & 0 & 0.105 \\
\hline Wyoming & 4 & 1.243 & 1.243 & 0 & 0 & 5.243 & 0.682 & 0.682 & 0 & 0 \\
\hline US & 5.452 & 1.366 & 0.76 & 0.48 & 0.126 & 6.819 & 1.413 & 1.064 & 1.014 & 0.323 \\
\hline
\end{tabular}

The first six numerical columns present the weighted average of the state, total local (county + town + district), county, town, district, and total combined tax rates. The final four columns present the weighted standard deviations of these rates within a state. All population weights are from the 2010 ACS. The total tax rate is the sum of the first two columns. 
Table 15: Tax Rates and SDs for December 2004

\begin{tabular}{|c|c|c|c|c|c|c|c|c|c|c|}
\hline State & State Rate & Total Local & County & Town & District & Total & sd(Total Local) & sd(County) & sd(Town) & sd(District) \\
\hline Alabama & 4 & 3.463 & 1.524 & 1.94 & 0 & 7.463 & 1.38 & 0.841 & 1.534 & 0 \\
\hline Alaska & 0 & 1.051 & 0.472 & 0.579 & 0 & 1.051 & 2.101 & 1.401 & 1.626 & 0 \\
\hline Arizona & 5.6 & 2.139 & 0.612 & 1.527 & 0 & 7.739 & 0.842 & 0.334 & 0.748 & 0 \\
\hline Arkansas & 6 & 2.028 & 1.2 & 0.823 & 0.005 & 8.028 & 0.898 & 0.492 & 0.802 & 0.051 \\
\hline California & 7.25 & 0.658 & 0.652 & 0.005 & 0 & 7.908 & 0.402 & 0.406 & 0.047 & 0 \\
\hline Colorado & 2.9 & 3.501 & 0.736 & 2.334 & 0.431 & 6.401 & 1.415 & 0.706 & 1.45 & 0.402 \\
\hline Connecticut & 6 & 0 & 0 & 0 & 0 & 6 & 0 & 0 & 0 & 0 \\
\hline Delaware & 0 & 0 & 0 & 0 & 0 & 0 & 0 & 0 & 0 & 0 \\
\hline District of Columbia & 5.75 & 0 & 0 & 0 & 0 & 5.75 & 0 & 0 & 0 & 0 \\
\hline Florida & 6 & 0.609 & 0.609 & 0 & 0 & 6.609 & 0.476 & 0.476 & 0 & 0 \\
\hline Georgia & 4 & 2.657 & 2.613 & 0.044 & 0 & 6.657 & 0.696 & 0.638 & 0.208 & 0 \\
\hline Hawaii & 4 & 0 & 0 & 0 & 0 & 4 & 0 & 0 & 0 & 0 \\
\hline Idaho & 6 & 0.061 & 0.056 & 0.005 & 0 & 6.061 & 0.192 & 0.161 & 0.108 & 0 \\
\hline Illinois & 6.25 & 1.296 & 0.385 & 0.526 & 0.385 & 7.546 & 0.971 & 0.362 & 0.509 & 0.336 \\
\hline Indiana & 6 & 0 & 0 & 0 & 0 & 6 & 0 & 0 & 0 & 0 \\
\hline Iowa & 5 & 1.474 & 0.643 & 0 & 0.83 & 6.474 & 0.684 & 0.474 & 0.006 & 0.371 \\
\hline Kansas & 5.3 & 1.543 & 0.922 & 0.62 & 0 & 6.843 & 0.639 & 0.343 & 0.549 & 0 \\
\hline Kentucky & 6 & 0 & 0 & 0 & 0 & 6 & 0 & 0 & 0 & 0 \\
\hline Louisiana & 4 & 4.38 & 2.469 & 1.663 & 0.248 & 8.38 & 0.751 & 2.15 & 2.117 & 0.857 \\
\hline Maine & 5 & 0 & 0 & 0 & 0 & 5 & 0 & 0 & 0 & 0 \\
\hline Maryland & 5 & 0 & 0 & 0 & 0 & 5 & 0 & 0 & 0 & 0 \\
\hline Massachusetts & 5 & 0 & 0 & 0 & 0 & 5 & 0 & 0 & 0 & 0 \\
\hline Michigan & 6 & 0 & 0 & 0 & 0 & 6 & 0 & 0 & 0 & 0 \\
\hline Minnesota & 6.5 & 0.107 & 0.001 & 0.106 & 0 & 6.607 & 0.226 & 0.031 & 0.224 & 0 \\
\hline Mississippi & 7 & 0.003 & 0 & 0.003 & 0 & 7.003 & 0.027 & 0 & 0.027 & 0 \\
\hline Missouri & 4.225 & 2.419 & 1.068 & 1.033 & 0.318 & 6.644 & 0.86 & 0.446 & 0.839 & 0.319 \\
\hline Montana & 0 & 0 & 0 & 0 & 0 & 0 & 0 & 0 & 0 & 0 \\
\hline Nebraska & 5.5 & 1.005 & 0 & 1.005 & 0 & 6.505 & 0.668 & 0 & 0.668 & 0 \\
\hline Nevada & 4.25 & 3.137 & 3.098 & 0 & 0.039 & 7.387 & 0.285 & 0.304 & 0 & 0.1 \\
\hline New Hampshire & 0 & 0 & 0 & 0 & 0 & 0 & 0 & 0 & 0 & 0 \\
\hline New Jersey & 6 & 0.003 & 0 & 0.003 & 0 & 6.003 & 0.076 & 0 & 0.076 & 0 \\
\hline New Mexico & 5 & 1.655 & 0.509 & 1.145 & 0 & 6.655 & 0.601 & 0.316 & 0.715 & 0 \\
\hline New York & 4.25 & 4.16 & 2.152 & 1.84 & 0.168 & 8.41 & 0.405 & 2.141 & 2.236 & 0.13 \\
\hline North Carolina & 4.5 & 2.548 & 2.5 & 0 & 0.048 & 7.048 & 0.149 & 0 & 0 & 0.149 \\
\hline North Dakota & 5 & 0.897 & 0.004 & 0.893 & 0 & 5.897 & 0.71 & 0.033 & 0.711 & 0 \\
\hline Ohio & 6 & 1.115 & 0.93 & 0 & 0.184 & 7.115 & 0.432 & 0.335 & 0.009 & 0.32 \\
\hline Oklahoma & 4.5 & 3.219 & 0.614 & 2.604 & 0 & 7.719 & 1.376 & 0.589 & 1.504 & 0 \\
\hline Oregon & 0 & 0 & 0 & 0 & 0 & 0 & 0 & 0 & 0 & 0 \\
\hline Pennsylvania & 6 & 0.217 & 0.217 & 0 & 0 & 6.217 & 0.417 & 0.417 & 0 & 0 \\
\hline Rhode Island & 7 & 0 & 0 & 0 & 0 & 7 & 0 & 0 & 0 & 0 \\
\hline South Carolina & 5 & 0.556 & 0.192 & 0.194 & 0.17 & 5.556 & 0.639 & 0.397 & 0.406 & 0.374 \\
\hline South Dakota & 4 & 1.596 & 0 & 1.457 & 0.139 & 5.596 & 0.944 & 0 & 0.812 & 0.684 \\
\hline Tennessee & 7 & 2.38 & 2.343 & 0.037 & 0 & 9.38 & 0.237 & 0.302 & 0.241 & 0 \\
\hline Texas & 6.25 & 1.512 & 0.131 & 1.011 & 0.37 & 7.762 & 0.712 & 0.221 & 0.675 & 0.423 \\
\hline Utah & 4.75 & 1.67 & 0.907 & 0.413 & 0.351 & 6.42 & 0.232 & 0.613 & 0.617 & 0.208 \\
\hline Vermont & 6 & 0.007 & 0 & 0.007 & 0 & 6.007 & 0.069 & 0 & 0.069 & 0 \\
\hline Virginia & 4 & 1 & 0.691 & 0.309 & 0 & 5 & 0 & 0.466 & 0.466 & 0 \\
\hline Washington & 6.5 & 1.864 & 0.357 & 1.131 & 0.375 & 8.364 & 0.434 & 0.622 & 0.866 & 0.557 \\
\hline West Virginia & 6 & 0 & 0 & 0 & 0 & 6 & 0 & 0 & 0 & 0 \\
\hline Wisconsin & 5 & 0.398 & 0.346 & 0 & 0.052 & 5.398 & 0.224 & 0.233 & 0 & 0.105 \\
\hline Wyoming & 4 & 1.245 & 1.245 & 0 & 0 & 5.245 & 0.64 & 0.64 & 0 & 0 \\
\hline US & 5.491 & 1.321 & 0.742 & 0.473 & 0.106 & 6.815 & 1.381 & 1.053 & 1.014 & 0.278 \\
\hline
\end{tabular}

The first six numerical columns present the weighted average of the state, total local (county + town + district), county, town, district, and total combined tax rates. The final four columns present the weighted standard deviations of these rates within a state. All population weights are from the 2010 ACS. The total tax rate is the sum of the first two columns. 
Table 16: Summary Statistics

\begin{tabular}{|c|c|c|c|}
\hline & Variable & $\begin{array}{c}\text { Mean } \\
(\mathrm{SD}) \\
\text { Full }\end{array}$ & $\begin{array}{c}\text { Mean } \\
(\mathrm{SD}) \\
2005-\end{array}$ \\
\hline \multirow{3}{*}{ Tax } & Total Tax Rate & 6.06 & 6.27 \\
\hline & State Tax Rate & 4.96 & 5.00 \\
\hline & Total Local & 1.08 & 1.27 \\
\hline \multirow[t]{6}{*}{ BLS } & $\ln$ (labor force) & $\begin{array}{c}14.47 \\
(.99)\end{array}$ & $\begin{array}{c}14.48 \\
(.99)\end{array}$ \\
\hline & unemployment & 6.17 & 6.59 \\
\hline & & $(2.36)$ & $(2.56)$ \\
\hline & $\%$ Male & & $\begin{array}{l}49.24 \\
(.72)\end{array}$ \\
\hline & $\%$ Senior & & 13.13 \\
\hline & & & $(1.50)$ \\
\hline \multirow{23}{*}{ ACS } & \% Less College & & 72.51 \\
\hline & Modian 4 co & & $\begin{array}{l}(5.68) \\
37.30\end{array}$ \\
\hline & Median Age & & $(2.23)$ \\
\hline & Ratio of Private : Public & & .16 \\
\hline & School & & $(.05)$ \\
\hline & \% Public Assistance & & 2.51 \\
\hline & & & $(.80)$ \\
\hline & Age of House & & 34.94 \\
\hline & & & $(8.79)$ \\
\hline & $\%$ Non Citizen & & 4.90 \\
\hline & & & $(3.31)$ \\
\hline & Rooms & & 5.51 \\
\hline & & & $(.33)$ \\
\hline & Race & & 78.89 \\
\hline & & & $(11.67)$ \\
\hline & $\ln ($ Income Per Capita) & & 10.15 \\
\hline & & & $(.16)$ \\
\hline & $\ln$ (Population) & & 15.16 \\
\hline & & & $(1.02)$ \\
\hline & $\ln ($ density $)$ & & 4.64 \\
\hline & & & $(1.41)$ \\
\hline & $\ln ($ Land Area $)$ & & 10.51 \\
\hline & & & $(1.41)$ \\
\hline
\end{tabular}

Table displays summary statistics averaged across months and states in the panel. The first column is for the complete sample and the second sample only includes the months where the ACS data are available (after 2005). 


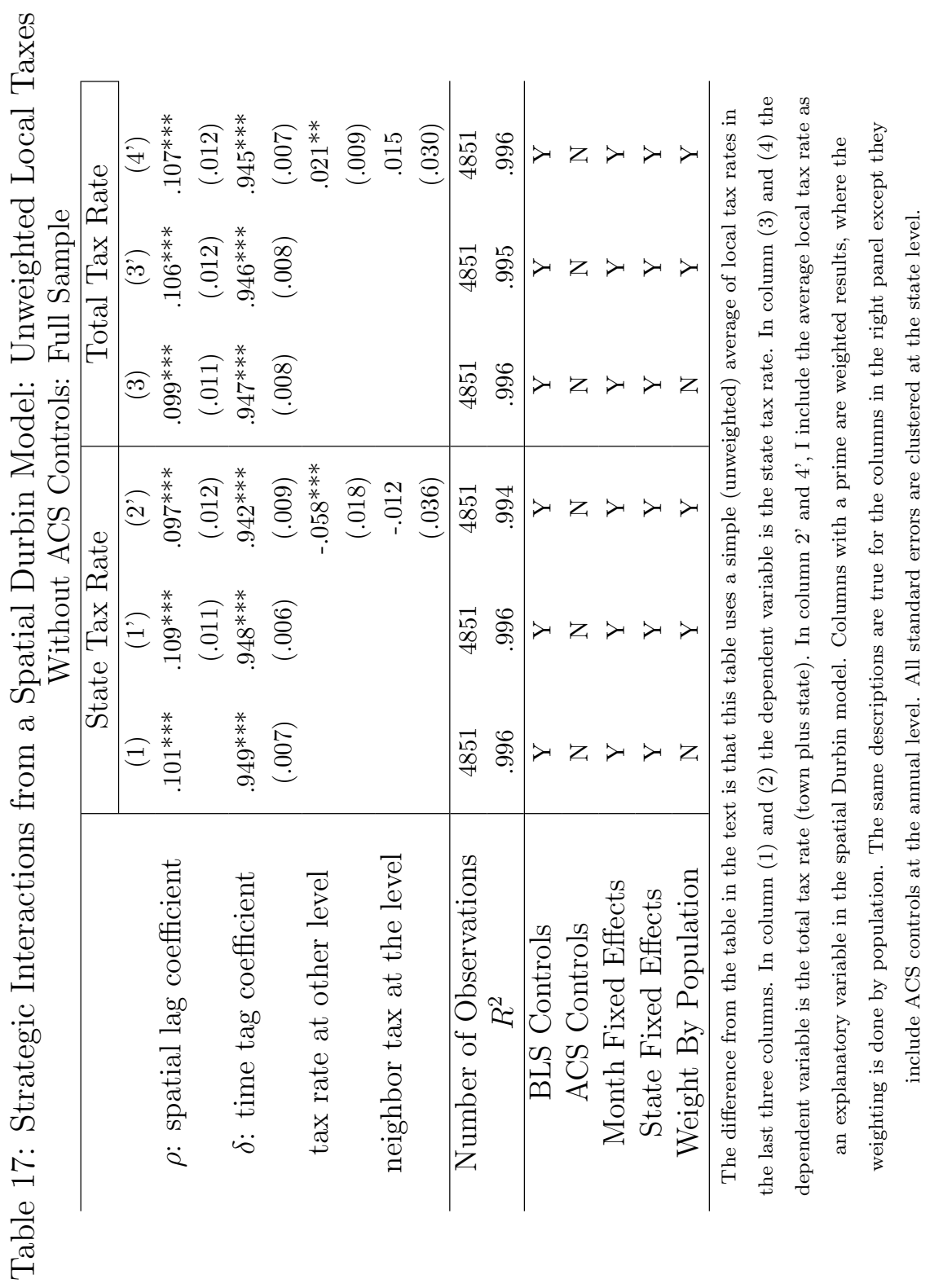

